\title{
THE POWER OF IMAGES: RE-EXAMINING THE WALL PAINTINGS FROM THE THRONE ROOM AT KNOSSOS
}

\author{
by Yannis Galanakis ${ }^{\mathrm{a}}$, Efi Tsitsa ${ }^{\mathrm{b}}$ and Ute Günkel-Maschek ${ }^{\mathrm{c}}$ \\ aniversity of Cambridge \\ ${ }^{b}$ Herakleion Archaeological Museum \\ 'University of Heidelberg
}

\begin{abstract}
The aim of this paper is to re-examine the painted fragments discovered by Arthur Evans and his team in the Throne Room at Knossos in 1900. We have tried to integrate systematically the extant archival data stored in the Ashmolean Museum in Oxford and the archaeological remains at Herakleion in an attempt to retrace the history of discovery of the paintings. In our view, the iconography of this programme places its execution at the onset of Late Minoan (LM) II. We see the inclusion of both 'traditional' (Neopalatial) and 'innovative' (Final Palatial) elements in the composition as suggestive of an attempt on behalf of the artist(s) and the commissioner(s) to blend artistic traditions in the creation of a new, yet still recognisable, image of power. We assess the implications stemming from this suggestion and interpret the decorative programme of the Throne Room at Knossos as part and expression of the emergence of the wanax ideology.
\end{abstract}

\section{INTRODUCTION}

The Throne Room at Knossos and its painted decoration are one of the most celebrated, yet highly contentious, topics of discussion in Aegean archaeology. Previous bibliography is marred by substantial confusion and misunderstanding stemming from a significant amount of imaginative speculation that has been piled over the years on top of Arthur Evans's Throne Room reconstructions. The latter are in themselves highly suspect and dependent on Evans's own firm ideas about the nature of Knossian society, its religion and symbolism.

The recent redevelopment of the Ashmolean Museum in Oxford and of the Archaeological Museum in Herakleion presented us with an excellent opportunity to re-examine the painted fragments discovered by Evans and his team in the Throne Room in 1900. It allowed us to retrace their excavation and to bring together the extant archival data, stored in Oxford, and the archaeological remains, housed at Herakleion, in an effort to identify the painted fragments that today can be attributed safely to the Knossian Throne Room. The conservation of some of the fragments, in preparation for their display at Herakleion, has helped clarify further the decorative programme of the Throne Room and of the paint layers and techniques used in its decoration.

For archaeological and stylistic reasons, discussed below, a Late Minoan (LM) II date is favoured for the execution of the Throne Room's decorative programme, which included 'traditional' (i.e. Neopalatial) and 'innovative' (i.e. Final Palatial) elements. The coexistence of these elements is, in our view, best interpreted as a conscious effort of the artist(s) and their commissioners to create a new, yet still recognisable, image of power - an image that represents an artistic as well as a political turning point between the Neopalatial and Final Palatial periods. Within this context, the Throne Room's decorative programme can be understood as part and parcel of a new, emerging, ideology one that was based on the transformation and subversion of material culture, and of images in particular.

\section{THE EXCAVATION OF THE THRONE ROOM AT KNOSSOS}

The painted fragments that form the focus of our study were discovered by Arthur Evans and his team, under the direction of Duncan Mackenzie, between I I and I8 April I900 in the palace at Knossos and 
more specifically in the 'Throne Room', a space also referred to in the original excavation notebooks as

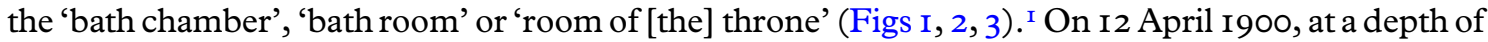
about $30 \mathrm{~cm}$ from the surface and almost in the middle of the north wall, there came to light the 'fresco with tree' (DM/DB I900. I, I3 April, 34) - one of the largest wall paintings to be discovered in situ at the site (Fig. 4): 'The N. wall of the bath room was brought partially into view near the surface and [a] wall painting, surmounted by a plain dado, began to appear with design resembling the branches of a palm tree' (DM/DB I900. I, I2 April, 24-5). More fragments came to light on I4 April on the north side of the west wall, showing 'grey palms' on a hilly 'red ground', with some fragments clearly having fallen out of place (DM/DB I900.I, I4 April, 37-8). In the next few days it transpired that paintings of a decorative character adorned the room's north-east corner and north and west walls but not the area of the 'bath chamber' proper, where only horizontal bands decorated the upper part of the redpainted walls.

The lifting of more painted fragments by Yannis Papadakis, from either side of the door in the west wall of the Throne Room, coincided on I8 April with a visit to Knossos by Emile Gilliéron, perre, who was to become Evans's chief artist for the Knossos excavations, specialising in the restoration of the paintings. Gilliéron was the first to recognise the existence of a 'griffin in part of [the] bath-room fresco' ( $A E / N B$ I900, I8 April, 48). His identification immediately convinced Evans, who noted in his diary that it now becomes clear that a guardian griffin stood on either side of the door leading to the room beyond the bath chamber' ( $A E / N B$ I900, I8 April, 48-9).

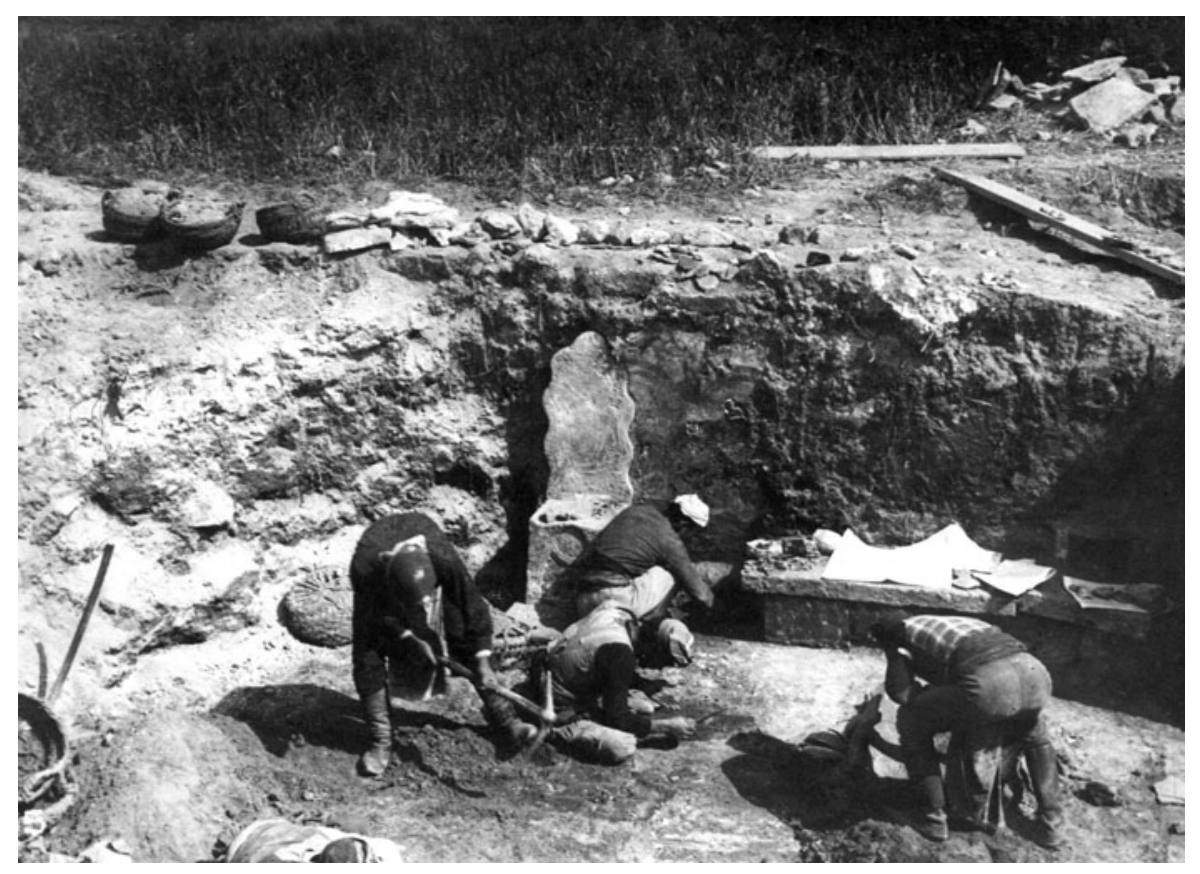

Fig. I. Excavating the Throne Room at Knossos, I2 April I900. PhEvans Book 8, 21, no. E. Top. 655 (= Evans 1935, fig. 88I). Courtesy of the Arthur Evans Archive, Ashmolean Museum, University of Oxford. 


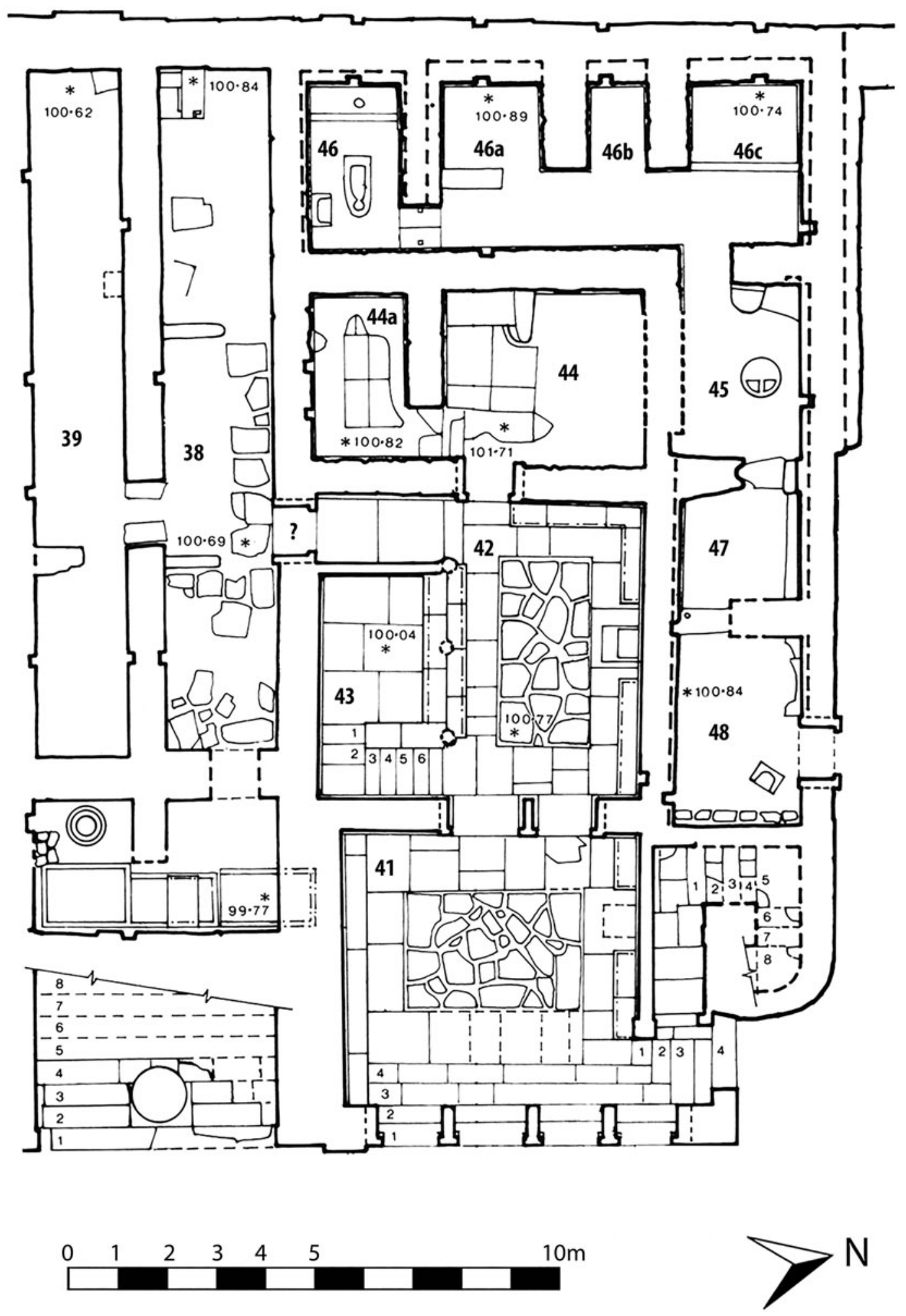

Fig. 2. Plan of the ground floor, West Wing, Throne Room complex, Palace at Knossos. Adapted by the authors from Hood I98I, ground plan. Note that the distance between throne and benches is not accurate (i.e. shorter in this drawing than it actually is $[\mathrm{c} .80 \mathrm{~cm}]$ ). Courtesy of the British School at Athens. 

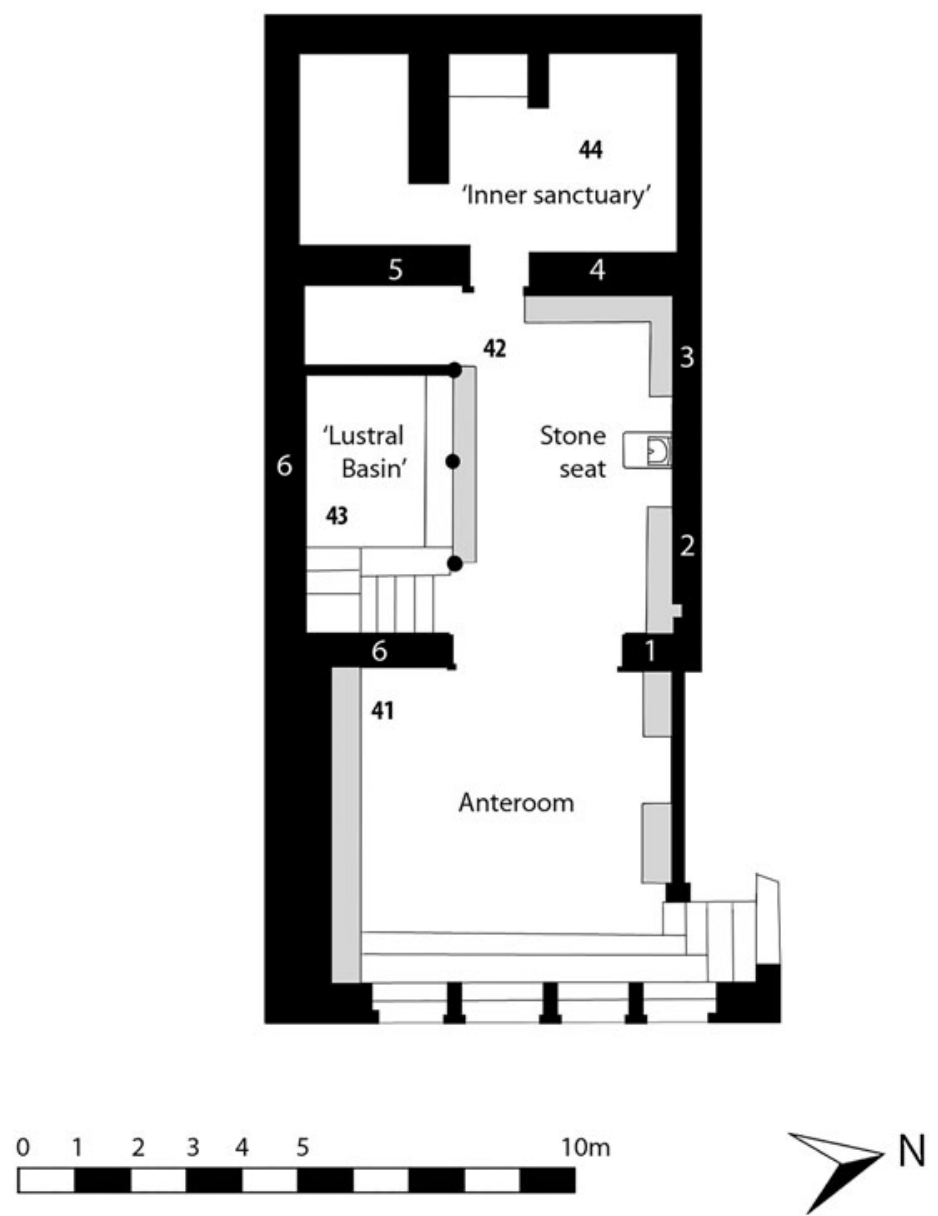

Fig. 3. Plan of the Throne Room proper (rooms 4I-44) in LM II. Benches indicated in light grey. It is not certain that the dithyron shown in Fig. 2 (between room 42 and room 4I) corresponds to an ancient reality. The available data are not sufficient and we cannot at present tie the dithyron to the reconstruction of Period III. Numbers in white indicate walls with painted decoration on them. By the authors.

This is all the information we have from the original notebooks kept by Evans and Mackenzie at the time of excavation with regard to the painted fragments discovered in the Throne Room at Knossos. With the help of the excavation photographs and the section drawings by Theodore Fyfe - Evans's first architect at Knossos - we can now attempt to piece together what was actually found in April 1900.

\section{PAINTED FRAGMENTS ATTRIBUTABLE TO THE THRONE ROOM}

Since the I960s, it has become clear that the extensive reconstructions of the Gilliérons, father and son, in the Throne Room at Knossos blended elements from various painted fragments and created a decorative programme which, as it currently stands, never existed (Hopkins I963; Palmer I969, 35-7). The first partial reconstruction of I9I3 (Fig. 5) combined elements from fragments belonging to all three walls of the Throne Room, including the 'fresco with tree' (e.g. the 'altar' and the animal's front paw). This partial reconstruction on the west side of the north wall - the area that yielded the fewest painted fragments - then became the prototype for the completion of 


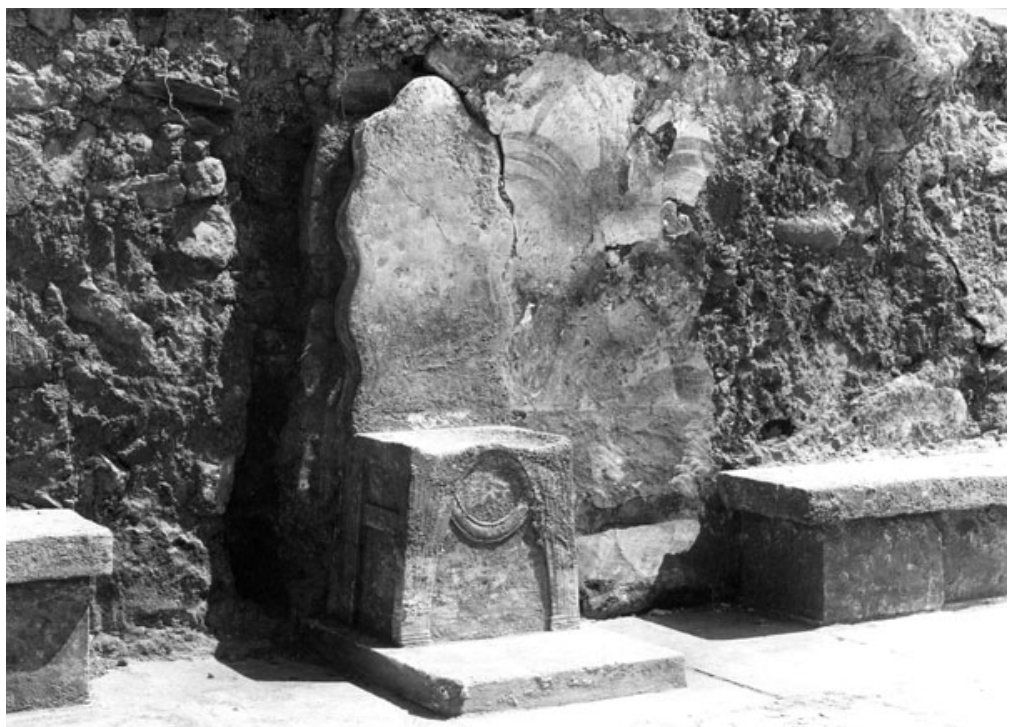

Fig. 4. The throne with the 'palm fresco' in situ, I900. PhEvans Book 8, I9, no. E.Top. 664b (= Evans I935, fig. 889 trimmed). Courtesy of the Arthur Evans Archive, Ashmolean Museum, University of Oxford.

the room's decoration in 1930. As a result, visitors to the Throne Room continue to admire to this day the work of the Gilliérons (Fig. 6), which bears little resemblance to the original fragments found in 1900. Most recently, in 2002-4, and as part of the conservation, consolidation and enhancement of the palace, the work of the Gilliérons was conserved anew (Tsitsa and Lakirdakidou 2008).

In identifying the painted fragments found in the course of excavation in the Throne Room, we have numbered the areas where they appear from ' $I$ ' to ' 6 ', starting with the north-east wall (Fig. 3):

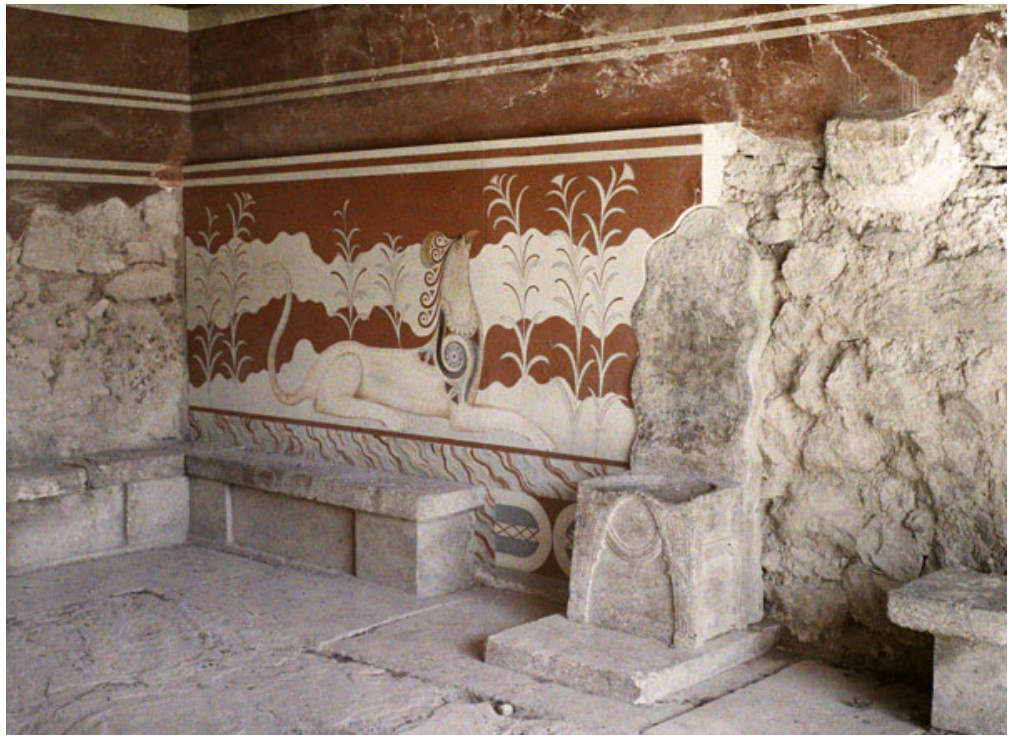

Fig. 5. The I9I3 reconstruction of the west part of the Throne Room's north wall. PhEvans Book 8, 20, no. E.Top. 2394. Courtesy of the Arthur Evans Archive, Ashmolean Museum, University of Oxford. 


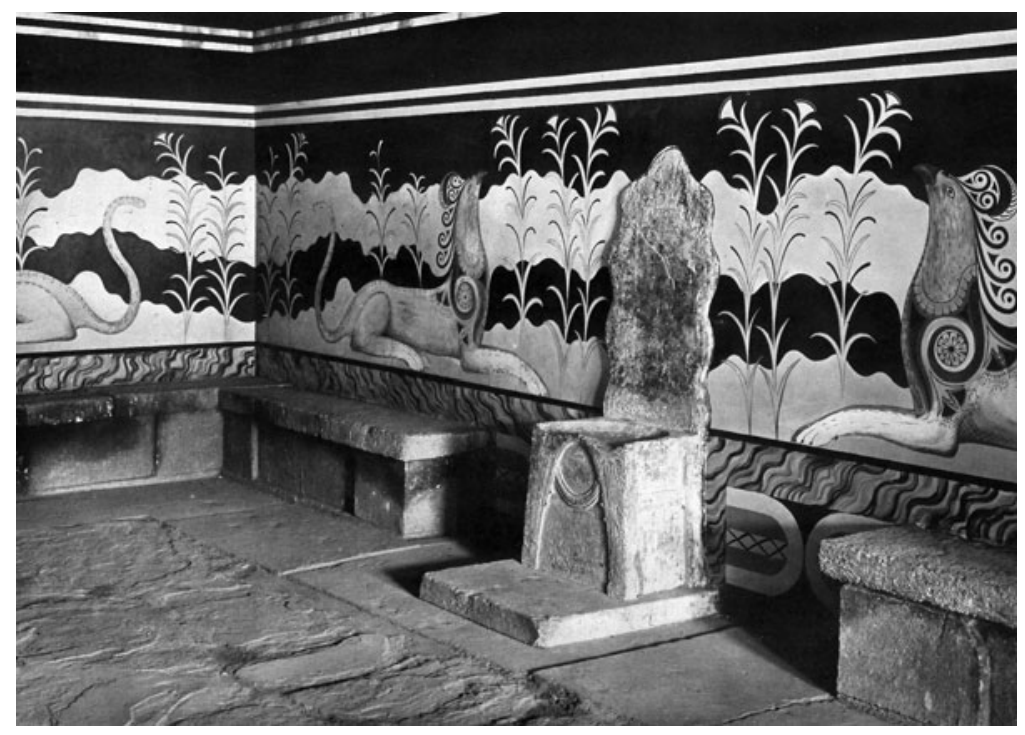

Fig. 6. The I930 reconstruction of the Throne Room's north wall. PhEvans Book 8, 24, no. E.Top. 656c (= Brown 2000, fig. 22c). Courtesy of the Arthur Evans Archive, Ashmolean Museum, University of Oxford.

I - north-east wall (corner): the lower part of the wall decoration is still in situ, though poorly preserved. The whereabouts of the upper part are unknown. Several archival photographs and drawings exist illustrating the painted fragments as found (Figs 7-8). Original dimensions: W: $c .90 \mathrm{~cm} \times \mathrm{H}$ : $152 \mathrm{~cm}$. Archival and excavation references: $A E / N B$ I900, I4 April, 38 and $K n D r A$ II.B/I and B/2 f-g (details of plants from north-east wall; probably by Theodore Fyfe).

The painted fragments on the north-east wall show four plants with dark blue-grey stems and leaves with red flowers. The two tall ones in the middle look more like papyrus-reed hybrids, what Evans first identified as 'sedges or rushes'. They were perhaps similar to the other papyrus-reed plants found elsewhere in the room. The other two plants, on either side of the two taller plants, probably depicted some kind of fern or hybridised papyrus-lotus. They are similar to the 'waz' (papyrus) motif on the shoulder of the best-preserved griffin from the south part of the west wall (more below). Similar plants and 'flowers' appear on both parts of the west wall. The undulating bands follow the room's general scheme and may add some weight to the idea of a balanced composition in the Throne Room, an idea to which we return below. Part of the 'veined stone' dado decoration was preserved under the lowermost undulating band.

2 - north wall, east part, abutting on the throne: 'fresco with tree' or 'palm fresco'. On permanent exhibition in gallery $\mathrm{I}_{3}$ in the Archaeological Museum at Herakleion. Max H: $163 \mathrm{~cm} \times \max \mathrm{W}: 80 \mathrm{~cm}$. Excavation and archival references: $A E / N B$ I900, I3 April, 32; $D M / D B$ I900.I, April I2-I4, 24-5 and 32-8; KnDrA I.WW/8 (Fig. 8), and numerous archival photographs.

In his first report, Evans (I899-I900, 40) mentions that 'at one point rises a palm tree', without, however, specifying the exact position of the palm within the walls of the Throne Room and without describing it in detail. In The Palace of Minos, no discussion of this particular fresco was ever included (cf. Evans I92 I, 253-4; I928, 493-9; I935, 90I-46, esp. 905-20), despite the fact that the excavation photos clearly show its position and subject matter (Evans I935, 906, fig. 88I, and 915, fig. 889; also Cameron 1976, vol. 3, III-I2, pl. I29).

It was only in the late I960s that a detailed macroscopic analysis was carried out by Mark Cameron (Fig. 9), who included it in his doctoral dissertation (Cameron 1970; 1976; 1987). ${ }^{2}$ Along with the work of Evans and the Gilliérons, Cameron's study has significantly influenced all successive attempts to reconstruct and interpret the composition on the north wall and the Throne Room as a whole. Although his work remains outstanding, Cameron based his study of this painting on the unconserved fragments, with all the problems that lack of conservation entails, especially with regard to details and colours. At the same time, he does not appear to have

2 Cameron (I976, vol. 3, Io) attributed the painting of the 'palm fresco' to the same workshop/artist ('School D') to which one could also ascribe the 'Cupbearer' and 'Procession' frescoes, the 'Dolphin' fresco, the West Porch dado and many others. The only other scholar who examined the fresco and produced an (unpublished) drawing of the 'palm fresco' is Ray Porter: Shank 2003, 4 and 66. 


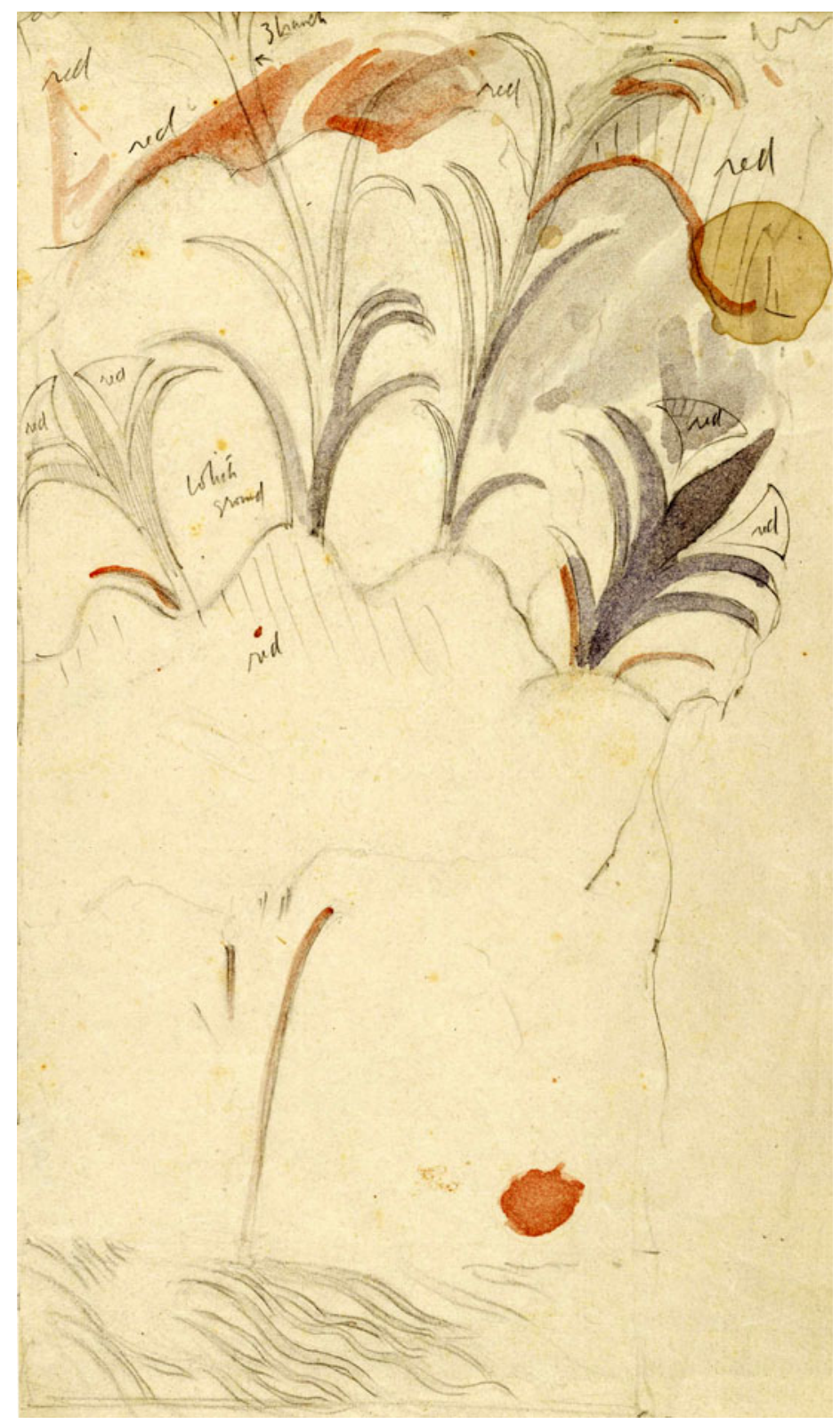

Fig. 7. Plants, undulating bands and part of the 'veined stone' from the north-east wall of the Throne Room. Pencil and watercolour on tracing paper. Probably Theodore Fyfe, c.I900-I. $K n D r A$ II.B/2 g. W: $98 \mathrm{~cm} \times \mathrm{H}$ : I03 cm. Courtesy of the Arthur Evans Archive, Ashmolean Museum, University of Oxford.

consulted the archival material stored at the Ashmolean. His work records, stored in the British School at Athens (e.g. $C A M$ I78-8I, $C A M$ 2II, $C A M$ 235, $C A M$ 262, $C A M$ 270, $C A M$ 382, $C A M$ 476, $C A M$ 523), reveal his extensive study of this fresco which he planned to publish - something that unfortunately never materialised, perhaps also due to his untimely death.

This large fragment has four curved indentations on the upper-left side, where it abutted the back of the throne, and is straight in the lower left side, where the plaster abutted the seat (Figs IO, II). The upper part and left side are incomplete but part of the base appears to have met the floor, judging also by Fyfe's I900 section drawing (Fig. 8) and the excavation photographs at the Ashmolean Museum. A close examination of the archival records actually suggests that the fragment discovered by Evans was originally about 20 per cent larger than the fragment preserved today in the Herakleion Museum (Fig. I2). The largest loss is observed on the upper right corner, where according 


\section{KNOS SOS (CRETE). Sections of Chambers,} shewing Fragments of Fresco, Fittings etc. as found.
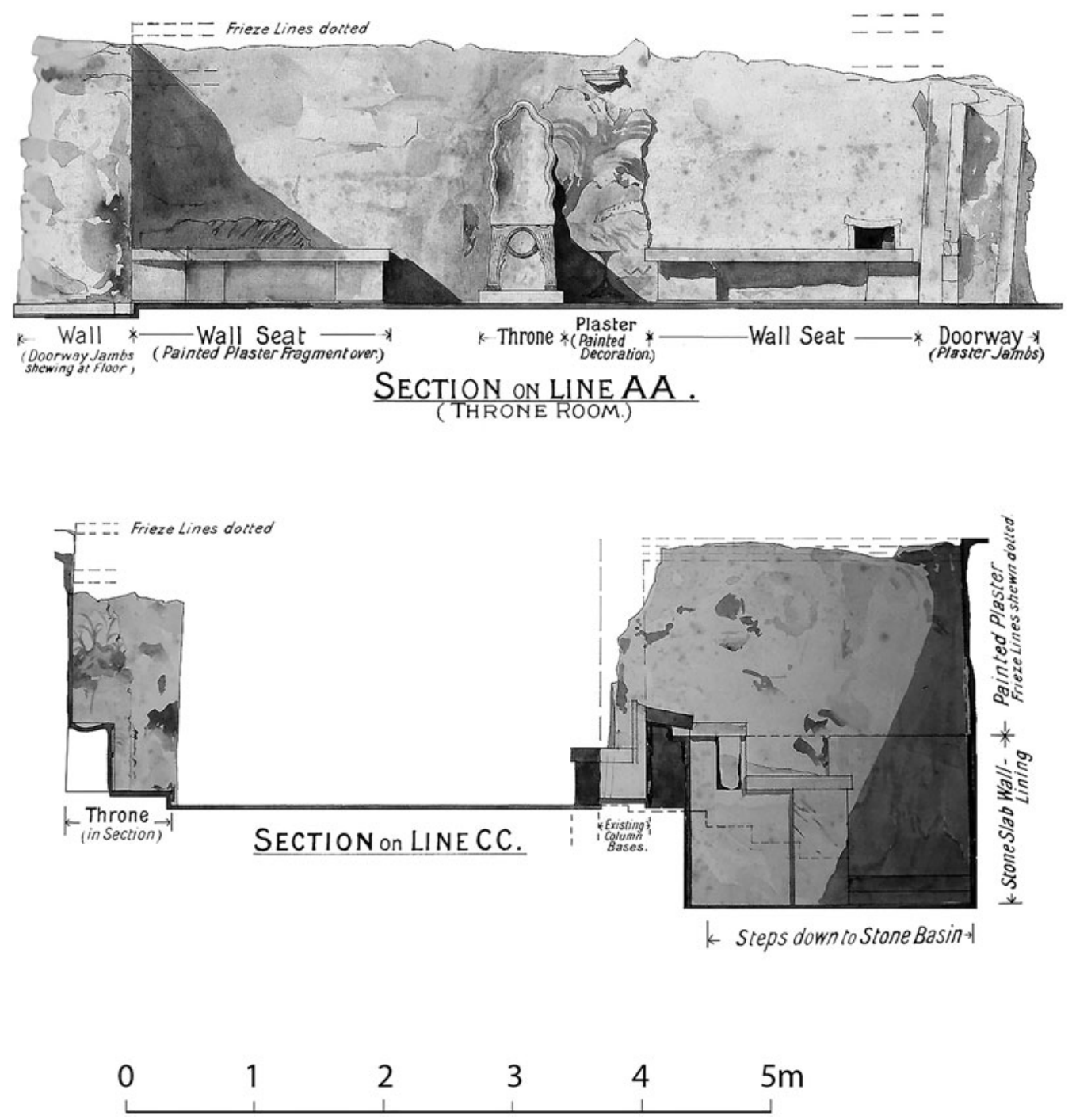

Fig. 8. Theodore Fyfe's drawing (I90I) showing fragments of fresco as found on the north and east walls of the Throne Room ( $K n D r A$ I.WW/8). Here only two sections are shown: 'section on line AA', which refers to the section from west to east (looking north), and 'section on line CC', which refers to the section from north to south (looking east). W: $43 \mathrm{~cm} \times \mathrm{H}: 57 \mathrm{~cm}$ (of complete drawing). Courtesy of the Arthur Evans Archive, Ashmolean Museum, University of

Oxford.

to archival information another group of three leaves was preserved at the time of excavation. This section, as suggested by the available photographs, ${ }^{3}$ probably fell off the wall - and was most likely destroyed - sometime in 1900 , i.e. prior to the detachment of the 'palm fresco'.

3 E.g. PhEvans Book 8, I9, no. E.Top. 664B (fragment in place) compared with I8, no. E.Top. 665A (fragment lost); PhEvans Book 8, 25, no. E.Top. 658 (fragment in place) compared with 22, no. E.Top. 656 (fragment lost); and PhEvans Book 8, 34, no. E.Top. 678B (fragment in place) compared with 33, no. E.Top. 2223 (fragment lost). All photos from 1900 . 


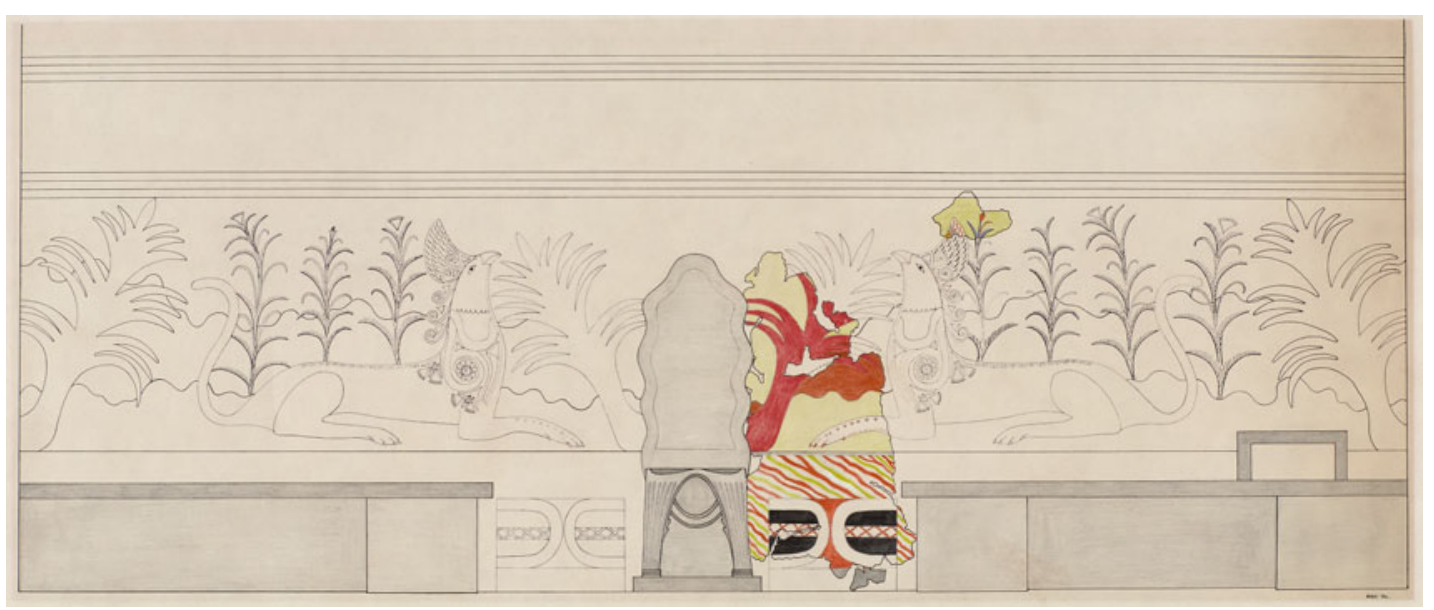

Fig. 9. The north wall of the Throne Room as reconstructed by Mark Cameron. Courtesy of the Mark Cameron Papers (CAM 523), British School at Athens.

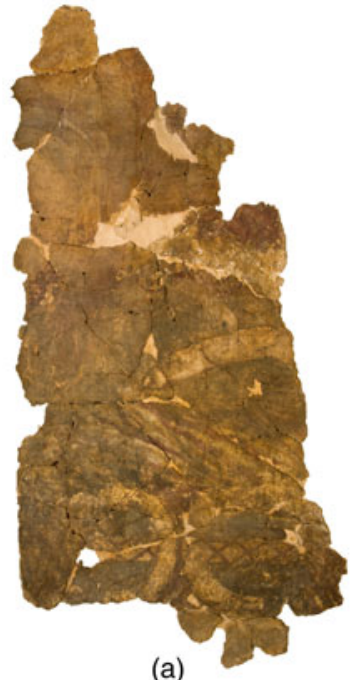

(a)

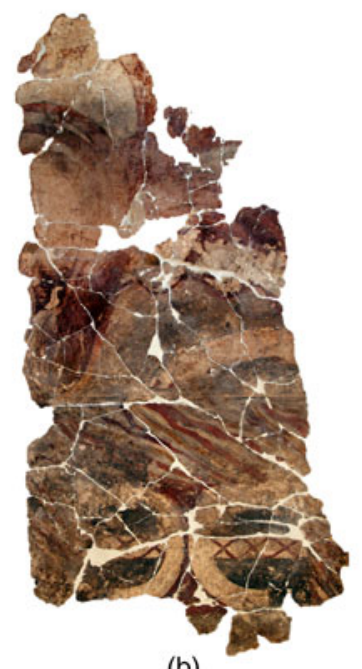

(b)

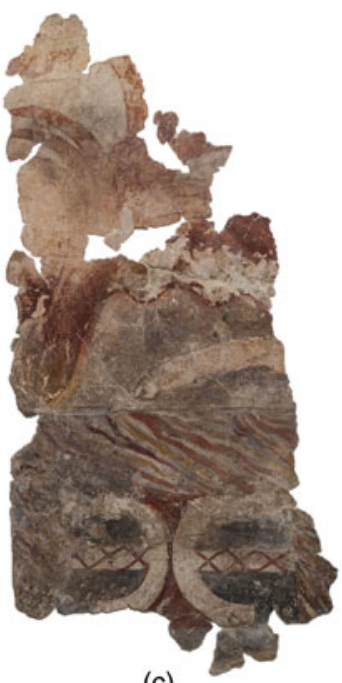

(c)

Fig. I0. Stages of conservation of the 'palm fresco': (a) prior to conservation, (b) in the course of conservation, (c) post-conservation. Courtesy of ҮП.ПО.А. Т.А.П. - Archaeological Museum of Herakleion, Hellenic Ministry of Culture and Sports - Archaeological Receipts Fund.

In terms of decoration, this fragment is divided into an upper and a lower part. The upper part is dominated by a dark-red palm with a large rounded base which springs 'diagonally upwards from the left edge at the junction of pictorial field and dado' (Cameron 1976, vol. 3, III). A closer examination of the rendering of the red trunk of the tree reveals considerable variation in colour, which begins with clear ochre and ends in dark red (Figs II, I3). The transition from one colour to another was achieved through the application of red on ochre (in the form of a solid line and of red dots). An auburn line runs along the right side of the tree's trunk, with the latter set very close to the actual stone seat without, however, 'touching' it. The colour difference between the red leaves and their red background is achieved through the use of different tones of red - light red for the leaves and dark red for the background - as well as 'impasto' white dots for the outline of the leaves (Fig. I3). The use of 'impasto' decoration - already observed by Cameron (I976, vol. 3, III-I2) - allows us to detect the presence of red leaves on a red background even when the preservation of one or the other is not good (for the use of 'impasto' in Aegean painting, see Cameron, Jones and Philippakis I977, I59, I65, I68, and Brysbaert 2008, II7, fig. 6:7).

Despite some partial loss since I900, the archival evidence - photographs and Fyfe's section drawing - helps us to ascertain securely that the palm originally had at least two pairs of three leaves on either side. It may have been crowned with a single large leaf set along the axis of the trunk, as suggested by Cameron in his reconstruction 


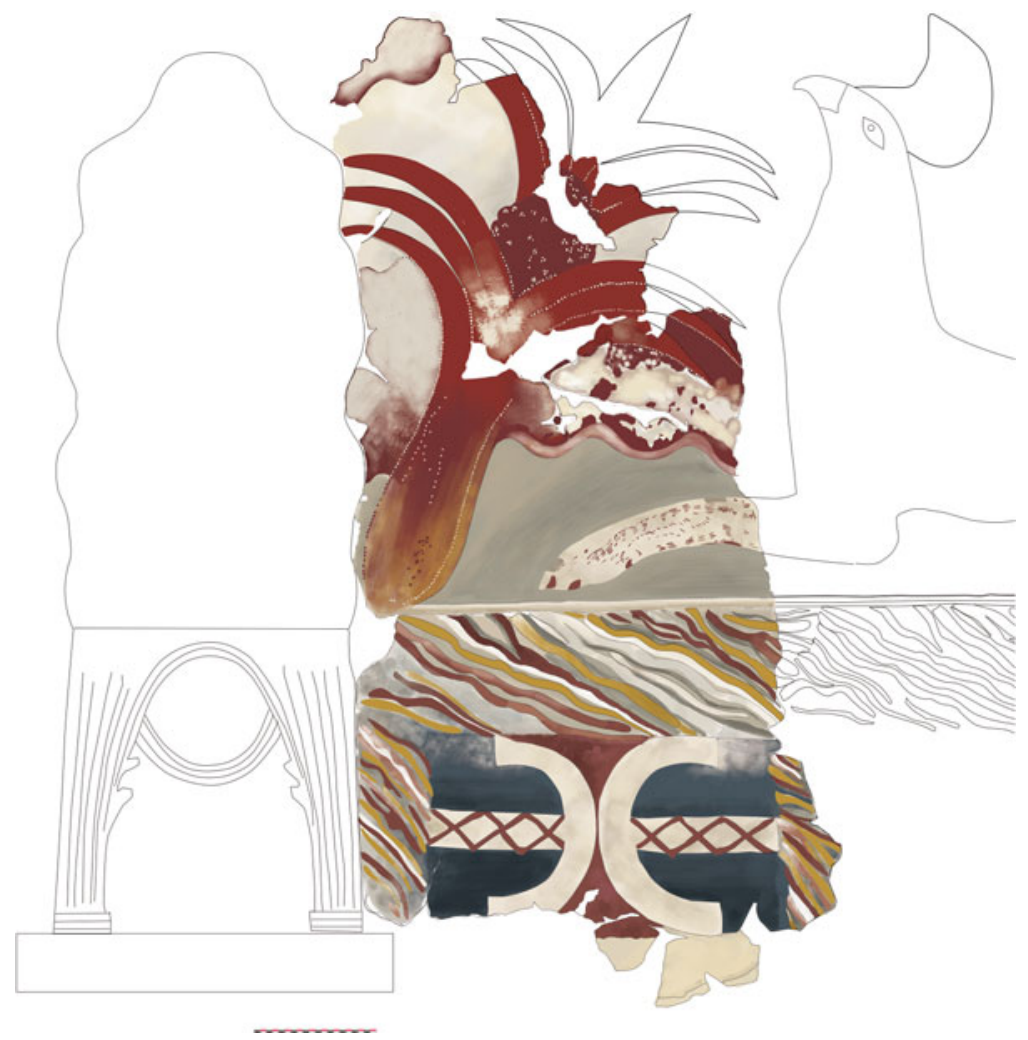

Fig. I I. Drawing by Pepi Stefanaki reproducing the current state of the 'palm fresco' following its conservation. Courtesy of Yannis Galanakis and Pepi Stefanaki.

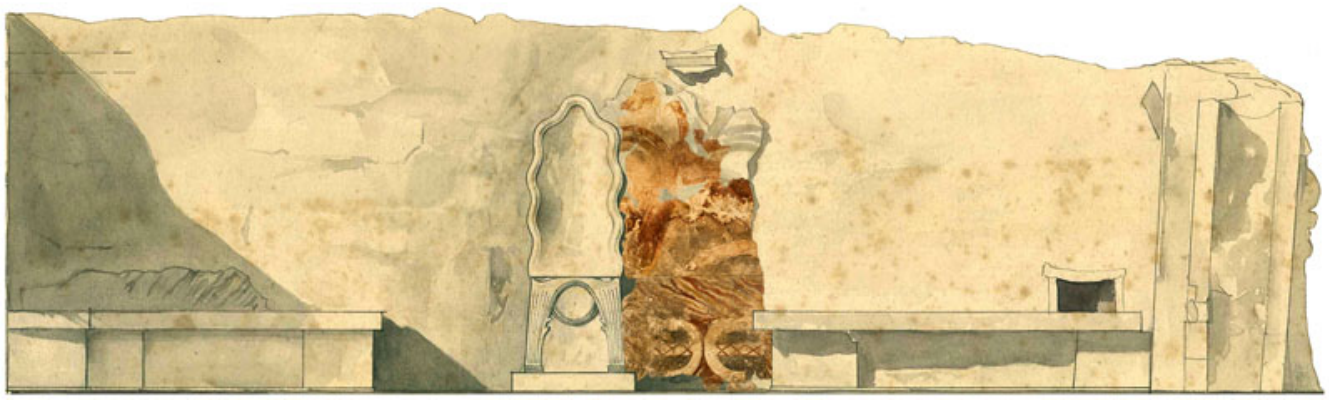

Fig. I2. The conserved 'palm fresco' set against Fyfe's original architectural drawing; about $20 \%$ of the fresco found on the north wall is no longer preserved. Courtesy of the Arthur Evans Archive, Ashmolean Museum, University of Oxford.

drawing (Cameron 1987, fig. 3 and fig. 7), though nothing remains of this part today (Fig. II).4 The three lower leaves on the left side of the trunk end up on the throne's edge, thus 'touching' it. The recent conservation of this fragment, as part of our study and for its display in the redeveloped Herakleion Museum, revealed the presence of

4 A single large leaf is observed in palms as early as the MM period and is also attested in Akrotiri on Thera and Tell el-Dab'a in Egypt. For Knossos, see Evans 1928, 493-9, esp. 496, fig. 30I; for Akrotiri: Vlachopoulos 2007; for Tell el-Dab'a: e.g. Bietak, Marinatos and Palyvou 2007, 56-6I, figs. 59 $A-B, 60$ and I50, fig. I38 and discussion by Marinatos at 146-8) There are also exceptions, such as the Nilotic landscape from the West House at Akrotiri: Televantou I994, 245-8. 


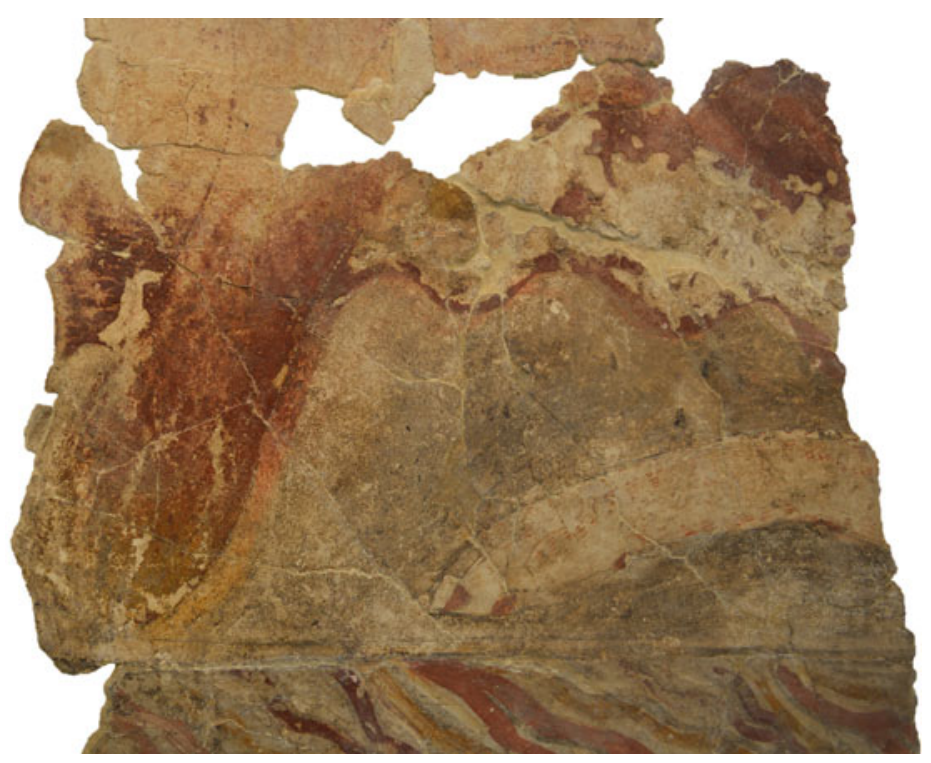

Fig. 13. A detail from the 'palm fresco' showing part of the veined dado, the base of the tree trunk, the animal's paw and the red leaves with 'impasto' outline set against a dark-red background. Courtesy of ҮП.ПО.А. Т.А.П. - Archaeological Museum of Herakleion, Hellenic Ministry of Culture and Sports - Archaeological Receipts Fund.

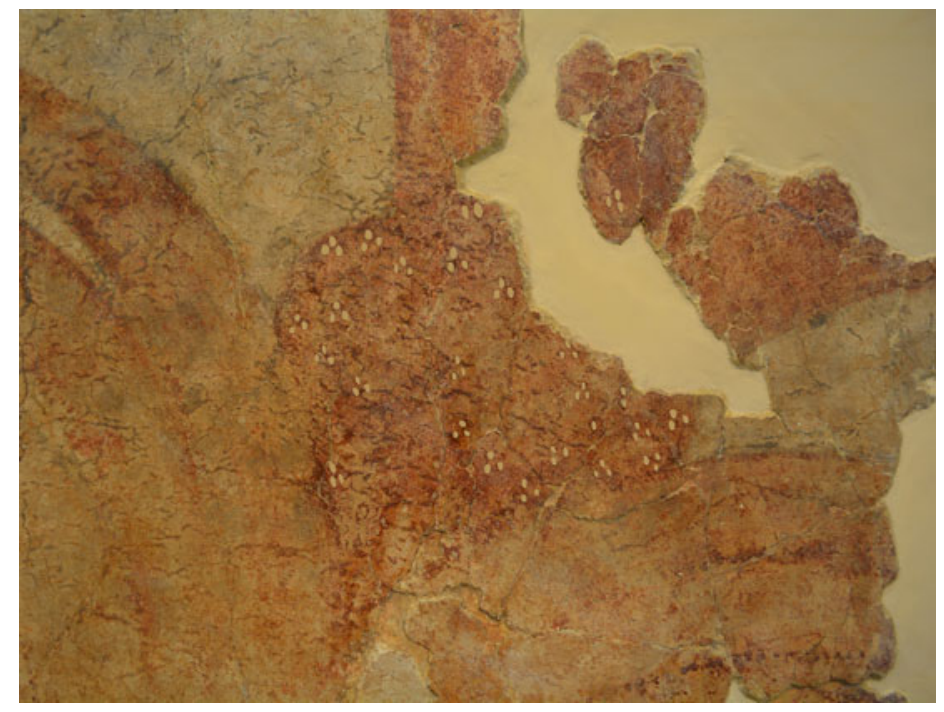

Fig. I4. The dates (white dots digitally enhanced for clarity) on the palm tree. Courtesy of $П$. ПО.А. Т.А.П. - Archaeological Museum of Herakleion, Hellenic Ministry of Culture and Sports - Archaeological Receipts Fund.

fruits (dates) on the central part of the tree (Figs I I, I4). Each fruit is indicated by three white 'impasto' dots. Most of them are oval in shape, which corresponds to the drupe of the Phoenix theophrasti palm. 5

Conservation and Raman spectroscopy have also helped to clarify the background arrangement on the upper part of this fresco: in total, four undulating bands (each between 20 and $22 \mathrm{~cm}$ in height) were observed. They alternate 


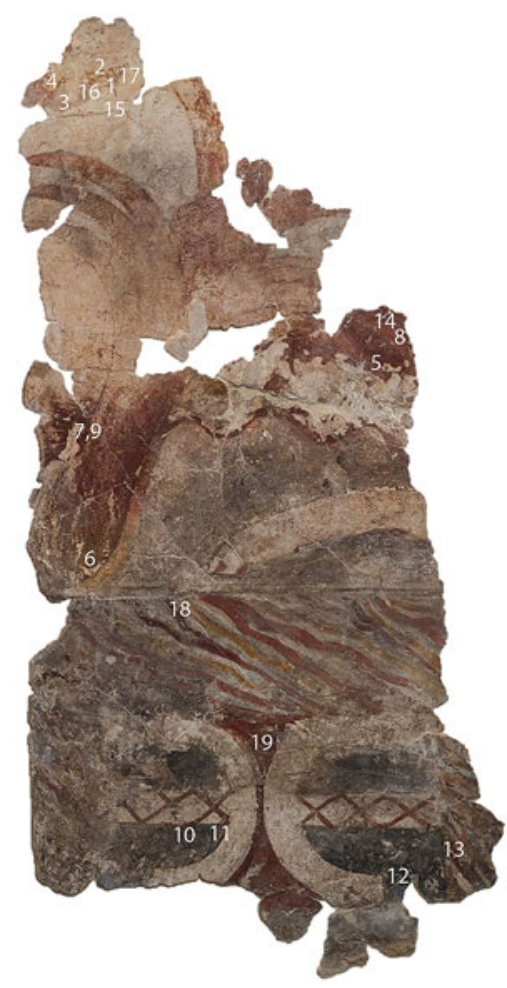

\begin{tabular}{|c|c|c|c|}
\hline No & Colour & Description & Raman results \\
\hline 1 & White & On the borderline of the white wavy band & $\mathrm{CaCO}_{3}$ \\
\hline 2 & Reddish & Red wavy band next to white spot \#1 & $\begin{array}{l}\mathrm{CaCO}_{3}, \mathrm{CaSO}_{4} .2 \mathrm{H}_{2} \mathrm{O} \text { and casein } \\
\text { (binding medium - original or part } \\
\text { of conservation) }\end{array}$ \\
\hline 3 & White & White over the wavy band & $\mathrm{CaCO}_{3}$ \\
\hline 4 & Red & Red area of wavy band & $\mathrm{CaCo}$ \\
\hline 5 & Red & Bright red area on the palm tree leaf & Fluorescence \\
\hline 6 & Yellow & Yellow paint over red on the base of palm tree & $\mathrm{CaSO}_{4} .2 \mathrm{H}_{2} \mathrm{O}$ \\
\hline 7 & Red & Bright red area on the base of palm tree & Fluorescence \\
\hline 8 & White (background) & Conservation treatment, filling & $\begin{array}{l}\mathrm{TiO}_{2} \text { (rutile synthetic from 1947) } \\
\text { and } \mathrm{CaSO}_{4} \cdot 2 \mathrm{H}_{2} \mathrm{O}\end{array}$ \\
\hline 9 & Red & Bright red area on the base of palm tree & Fluorescence \\
\hline 10 & Grey & Grey on the left side of the altar base & $\mathrm{CaSO}_{4} .2 \mathrm{H}_{2} \mathrm{O}$ \\
\hline 11 & Grey & Grey on the left side of the altar base & Carbon black \\
\hline 12 & Grey & Grey on the right side of the altar base & Carbon black \\
\hline 13 & Yellow & Yellow on the 'pseudo-marble' representation & Fluorescence (hematite) \\
\hline 14 & Red & Bright red area on the palm tree leaf & $\mathrm{Fe}_{2} \mathrm{O}_{3}$ (hematite) \\
\hline 15 & White & White background on the wavy band & $\mathrm{CaCO}_{3}$ \\
\hline 16 & Red & Red wavy band next to $\# 5$ & $\mathrm{SiO}_{2}$ \\
\hline 17 & Reddish & Red wavy band next to white spot \#15 & $\mathrm{CaCO}_{3}$ and $\mathrm{CaSO}_{4} \cdot 2 \mathrm{H}_{2} \mathrm{O}$ \\
\hline 18 & White (filling) & Conservation treatment, filling & $\mathrm{CaSO}_{4} \cdot 2 \mathrm{H}_{2} \mathrm{O}$ \\
\hline 19 & Red & $\begin{array}{l}\text { Dark red on the 'pseudo-marble' } \\
\text { representation }\end{array}$ & No spectrum \\
\hline
\end{tabular}

Fig. I5. Summary of the results of the Raman micro-spectroscopy study carried out on the 'palm fresco' by A. Philippidis, P. Siozos, K. Melessanaki and D. Anglos of the IESLFORTH with assistance from E. Tsitsa and Y. Galanakis. A mobile Raman microspectrometer (HE 785, JY Horiba) was used to study I9 spots (nos I-I9). The beam was focused on the sample surface through a microscope objective lens that illuminated an area of diameter around $50 \mu \mathrm{m}$. The beam power on the sample was in the range $0.05-5.5 \mathrm{~mW}$. Typical exposure time was $20 \mathrm{sec}$ per scan, while IO scans were averaged. Courtesy of $\Upsilon П$. ПО.А. Т.А.П. - Archaeological Museum of Herakleion, Hellenic Ministry of Culture and Sports - Archaeological Receipts Fund.

between white (or light grey) and dark red. This arrangement, which is securely documented on the painted fragments from the west wall, is also attested in the north-east corner mentioned above. Contrary to Cameron (1976, vol. 3, I97; 1987) and subsequent reconstructions that considered this feature a mistake of the I930 restoration, the four undulating bands actually form the most secure element of the Evans-Gilliéron reconstruction. Although spectroscopy in spots nos 2, 3, 4 and I6 (Fig. I5) did not conclusively prove the existence of a red undulating band in the uppermost left part of the fragment abutting to the throne (e.g. no clear traces of hematite $\left[\mathrm{Fe}_{2} \mathrm{O}_{3}\right]$ were identified), macroscopic observation appears to suggest that here too the background colour was red. The persistence of the ancient artist(s) in maintaining the four undulating bands may also explain what looks like a rather odd choice, i.e. to represent the red leaves of the palm against a red background. ${ }^{6}$

To the right of the palm an animal's paw is visible (four toenails, one flaked away). Originally, it was identified by Evans as belonging to an 'eel', which he thought appropriate for a riverine landscape, based on his interpretation of the four undulating bands as representing hills and flowing rivers (Evans I899-1900, 40). However, soon after the discovery of the west wall of the Throne Room, which yielded the two best-preserved griffins, Evans decided to interpret it as the front paw of a griffin (Evans $1899-1900,39-40) .7$ In collaboration with the Gilliérons, Evans used the paw from the 'palm fresco' in the reconstruction of the best-preserved griffins on the west wall of the

6 A similar overlap can be observed in the 'Fresco of the Procession', where the blue kilts of some of the offeringbearers were executed against a blue background (detail in Dimopoulou-Rethemiotaki 2005, I84).

7 A griffin is a hybrid (body of a feline - a panther or lion - and the head of a bird of prey - eagle or griffon vulture). Crowley (1989, I82) has argued convincingly about the Mitannian griffin as the inspiration for the Aegean counterpart in MM times. In the Aegean, the form is typically that of a vulture-headed lion. On griffins in Aegean art see Zouzoula 2007. 
Throne Room, especially the one from the south part of the west wall, i.e. the griffin facing right towards the entrance to the so-called 'inner sanctuary's ( $K n D r A$ II.B/2a-I = Evans I935, fig. 884 and fig. 894).

Although no front paws are actually preserved on the two griffins framing the door to the 'inner sanctuary', the skin colour of the beast's paw in the 'palm fresco' is the same as that on the best-preserved griffin on the south part of the west wall. This skin colour convention is suggestive to us that here too we are dealing with a griffin. Moreover, similarities observed in the rendering of the paw (to indicate hair texture and depth) and the hind leg of the bestpreserved griffin add further support to the view that the beast to the right of the palm was indeed a couchant griffin.

Between the upper and lower parts of the 'palm fresco', there are two horizontal, though not entirely straight, incised lines drawn with a sharp tool. These incisions offered guidance for the planning of the painted surface. They were drawn while the surface was still damp, suggesting that the palm fragment should, in principle, be considered a fresco (Brysbaert 2008, II3 and II6, who also stresses that these lines would make more sense when a 'buon fresco' is planned than a 'secco' painting). The reason that a sharp instrument might have been preferred here - and only on that spot, judging by the other extant fragments - might be due to the effort of the ancient artist(s) to align these two lines to the nearby throne, since its back could have posed some problems standing out from the surrounding plaster, and with the bench so close they may indeed have decided to go 'freehand'. In the 'palm fresco', the artist(s) may have used the lowermost level of the back of the throne, just above the seat, as the guide for the upper incised line; the latter sits immediately under the tree and paw of the animal. The actual level of the seat, before it starts getting hollow, was used as the guide for the lowermost incised line, just above the 'veined stone' dado.

In the lower part, and immediately under the horizontal lines, we find part of the 'veined stone' dado decoration which is featured on all the walls in the Throne Room where figural painting appears. The conservation has helped bring to light the impressive colour gradation of the 'veined stone' decoration. The artist(s), having already placed the basic colours (red, brown-red, grey-black and ochre), used a brush to briskly pass a layer of impasto-lime over the 'veins' (wavy lines). The result is the creation of a strong pink (white on red) and yellow tint (white on ochre; for the use of red [hematite: $\mathrm{Fe}_{2} \mathrm{O}_{3}$ ] see Fig. I5:I4).

Within the dado, and surrounded on three sides by 'veined stone' decoration, we find the 'altar-base': contrary to all existing reconstruction drawings (e.g. Evans I935, pl. XXXII, 9II, fig. 884 and 919-20, fig. 894), the white impasto band outlining the 'altar' does not run all the way to the edge of the 'veined stone' imitation, but stops almost midway. In this respect, the shape of the incurved structure clearly echoes that of 'altar-bases' in Neopalatial and Final Palatial representations. While slender versions of the 'altar' do occur in LM IA/LC I wall painting (e.g. on the wooden 'doors' of the 'tree-shrine' depicted on the east wall of the lustral basin in Xeste 3 at Akrotiri: Vlachopoulos 2008, 496, fig. 4I:IO), the 'cut-out' style applied in the rendering of this object in the 'palm fresco' is unprecedented in Minoan wall painting at that time. 9 Placed against a horizontal band, the 'altar' in the 'palm fresco' recalls the line-up of load-bearing incurved bases in front of a triple red horizontal band in the wall painting of the 'Seated Goddess' in Xeste 3 at Akrotiri. The use of lattice pattern as a filling motif in the white horizontal band on both sides of the 'altar' in the Throne Room fresco has no parallels in Minoan art, though the pattern itself is well known from wall painting and seal imagery (more below).

For the lowermost pieces of this fresco, now resembling a grey band, Evans and Cameron were convinced that colours were obscured by fire (Cameron 1976, vol. 3, II2 with earlier references). Our examination suggests that the deformation in the lowermost part of the fresco is a result of humidity and fungal infection, which developed on its surface over the course of time. The excellent colour preservation (e.g. of the 'veined stone') further reinforces, in our view, this idea. This is not to say that the palace was not burned down, but that our examination did not detect any traces of fire on the wall paintings from the Throne Room.

A small fragment above the 'palm fresco' can be seen in the archival photographs (estimated L: $25 \mathrm{~cm} \times$ estimated $\mathrm{H}: \mathrm{I} 5 \mathrm{~cm}$ ). It included part of the lowermost register of three bands ('frieze lines' according to Fyfe): white for the lowermost band, followed by red in the middle and most likely off-white/grey for the uppermost (Figs 5, I2). This fragment formed part of the lowermost zone of bands decorating the upper part of the north wall. Fyfe used this piece, along with similar fragments on the west wall and the lustral basin, ${ }^{\mathrm{IO}}$ as his guide for the reconstruction of the room's original height. ${ }^{\text {II }}$ In situ until 1930, the present location of this fragment is unknown.

8 The 'inner sanctuary' was originally described by Evans as 'the inner room' or 'stone lamp room'. It was interpreted as 'probably a wardrobe' or a 'bedchamber': $A E / N B$ I900, I6 April, 46 and I8 April, 49. It is also mentioned as a 'place for sleep or siesta' (Evans I899-I900, 40). Apart from a pedestalled lamp, some gold foil and the silver core of a bracelet, nothing else was found there.

9 For a later example, see the 'cut-out'-style altar from Pylos: Lang I969, I05, pls 46, I32, no. 3 C 20.

Io The lines differ in thickness and colour gradation between the Throne Room proper and the lustral basin: in the latter case, they are thicker than those in the rest of the main room. The colour gradation is nicely captured in Fyfe's I90I drawing (on which the subsequent reconstruction by Lambert in I9I7 was based): $K n D r A$ II.B/4. See also Evans I935, 912, fig. 885 (Fyfe's drawing).

II The original height of the Throne Room is not known: its walls were preserved to a height of $c .1 .90-2 \mathrm{~m}$ during excavation, with the wall to the east of the throne preserved to $c .1 .80-1.90 \mathrm{~m}$. The ceiling now stands at about $2.75 \mathrm{~m}$ from the floor. 


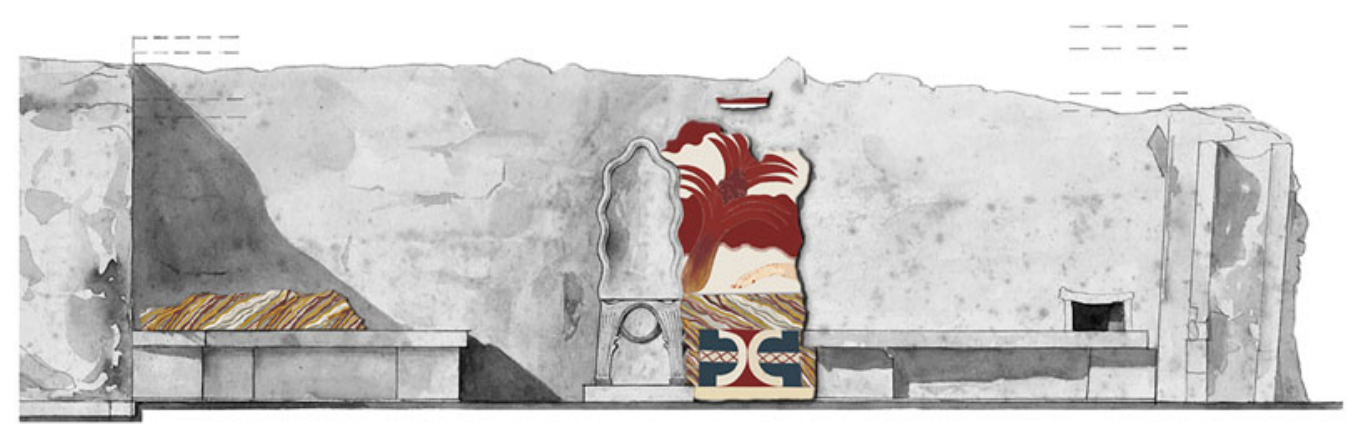

Fig. I6. North wall fragments juxtaposed onto Fyfe's drawing. Prepared by and courtesy of Ute Günkel-Maschek.

3 - north wall, west part (Fig. I6): a relatively large fragment with 'veined stone' dado decoration just above the bench shown in Fyfe's 1900 section drawing. The current whereabouts of this fragment are unknown. Estimated L: $120 \mathrm{~cm} \times \max \mathrm{H}: 25 \mathrm{~cm}$. Archival reference: $K n D r A \mathrm{I}$.WW/8. No reference is made to this fragment in the excavation notebooks.

This is the only painted fragment that we can securely assign to the west side of the throne. The 'veins' are moving in the other direction from those on the 'palm fresco'. It remained on the wall after the removal of the latter, as suggested by a photo now at the Ashmolean Museum (PhEvans Book 8, 33, no. E.Top. 2398). It had already been removed during the decoration of the west part of the north wall by the Gilliérons in I9I3. A fragment from this fresco may have turned up in 1973 (Cameron 1976, vol. 3, I96, who notes that the Gilliérons reversed the direction of the wavy lines in the dado on either side of the throne).

Theodore Fyfe's architectural drawing clearly illustrates the painted fragments as found on the north wall of the Throne Room at Knossos (Fig. 8): the 'palm fresco' and a band fragment on the east side of the throne, as well as part of the 'veined stone' dado decoration on the west side. The section drawing, along with the excavation notebooks and archival photographs, makes it clear that we have no evidence for the presence of a griffin or an 'altar' on the west side of the throne as assumed by Evans, the Gilliérons and Cameron and all reconstructions ever since (a smudge visible to the west of the throne on Fig. 8 is exactly that - just ink, not a painted fragment). The 'symmetry and aesthetic balance' in the design and overall composition of the Throne Room (Cameron 1976, vol. 3, 197) is therefore conjectural and needs to be explained rather than taken for granted - a point that we develop further below.

4 - west wall, north part (Figs I7, I8): panel with painted fragments (in storage in the Archaeological Museum at Herakleion). Dimensions of panel: W: $23 \mathrm{I} \mathrm{cm} \times \mathrm{H}: 140 \mathrm{~cm}$. Archival and excavation references: $A E / N B$ I900, I4 April, 38; $D M / N B$ I900.I, I4 April, 37-8; a reconstructed, left-facing griffin on the north part of the west wall appears in two of Fyfe's drawings that later formed the basis of Lambert's I9I7 drawing of the reconstructed Throne Room, $K n D r A$ II.B/4-5 (esp. B4a drawn in I90I) and Evans I935, frontispiece (pl. XXXIII); fragments from this part of the west wall are visible en masse in several archival photographs: e.g. PhEvans, Book 8, 33, no. E.Top. 2223 and 34, no. E.Top. 678c; also Cameron 1976, vol. 3, 98 and IIO-II, pls III $d$ and I28.

This panel was studied in detail by Elizabeth Shank as part of her doctoral dissertation (Shank 2003; also Shank and Balas 2003; Shank 2007). It consists of more than 30 fragments which can be grouped in 23 pieces as identified in Fig. I $7 a$. Most of them relate to the decoration of the north part of the west wall (e.g. nos I-9, I5-2I) and a good number can also be reconstructed with some certainty (Fig. I $7 b: \mathrm{I}$ ). No 'veined stone' dado decoration is preserved among the fragments. However, as this pattern is attested in the north-east corner, on either side of the throne on the north wall, and in the south part of the west wall, we believe that this feature also appeared on the north part of the west wall.

Based on the available fragments, a left-facing griffin can be identified, the chest of which bears a very close resemblance to that of the right-facing griffin on the west wall on the other side of the door. In front of this couchant griffin there are three papyrus-reed hybrids (same as on the south part of the west wall) (Fig. I9). The whole scene is set against four undulating bands, alternating between off-white and red. Above the undulating bands, there are two registers of horizontal bands. The lowermost register consists of three bands (white, red, and off-white/grey, from bottom to top). Two thin red-coloured bands contour the lowermost white band and two narrow white bands contour the off-white/grey band. The uppermost register has a similar arrangement but the width of the bands appears to be slightly different. Although not much remains of the griffin or the floral decoration, the extant fragments from the north part of the west wall (including the beast's tail, Fig. I7a:18-19, and part of the vegetation, Fig. I7a:17, Fig. I7a:19-20) appear to be identical to that on the south part of the west wall, further reinforcing the presence of a balanced composition on either side of the door leading to the 'inner sanctuary'. 


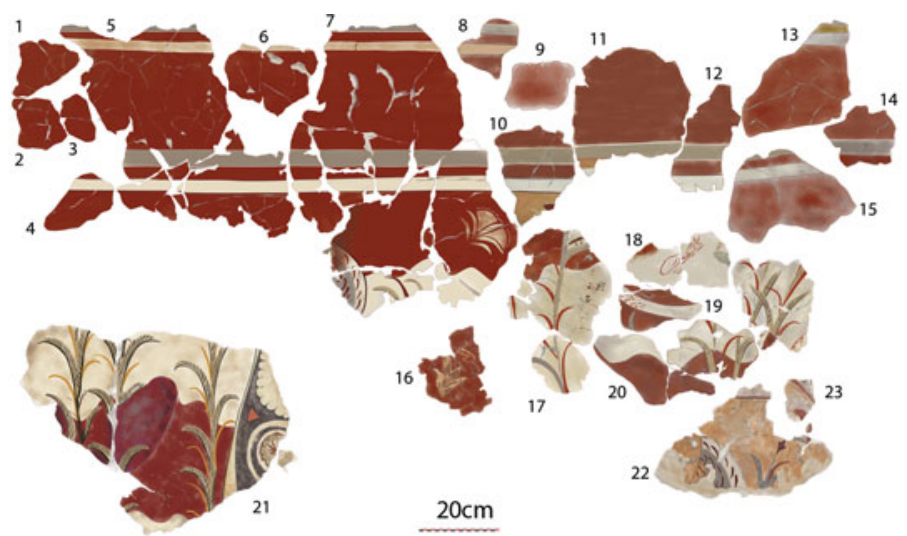

(a)

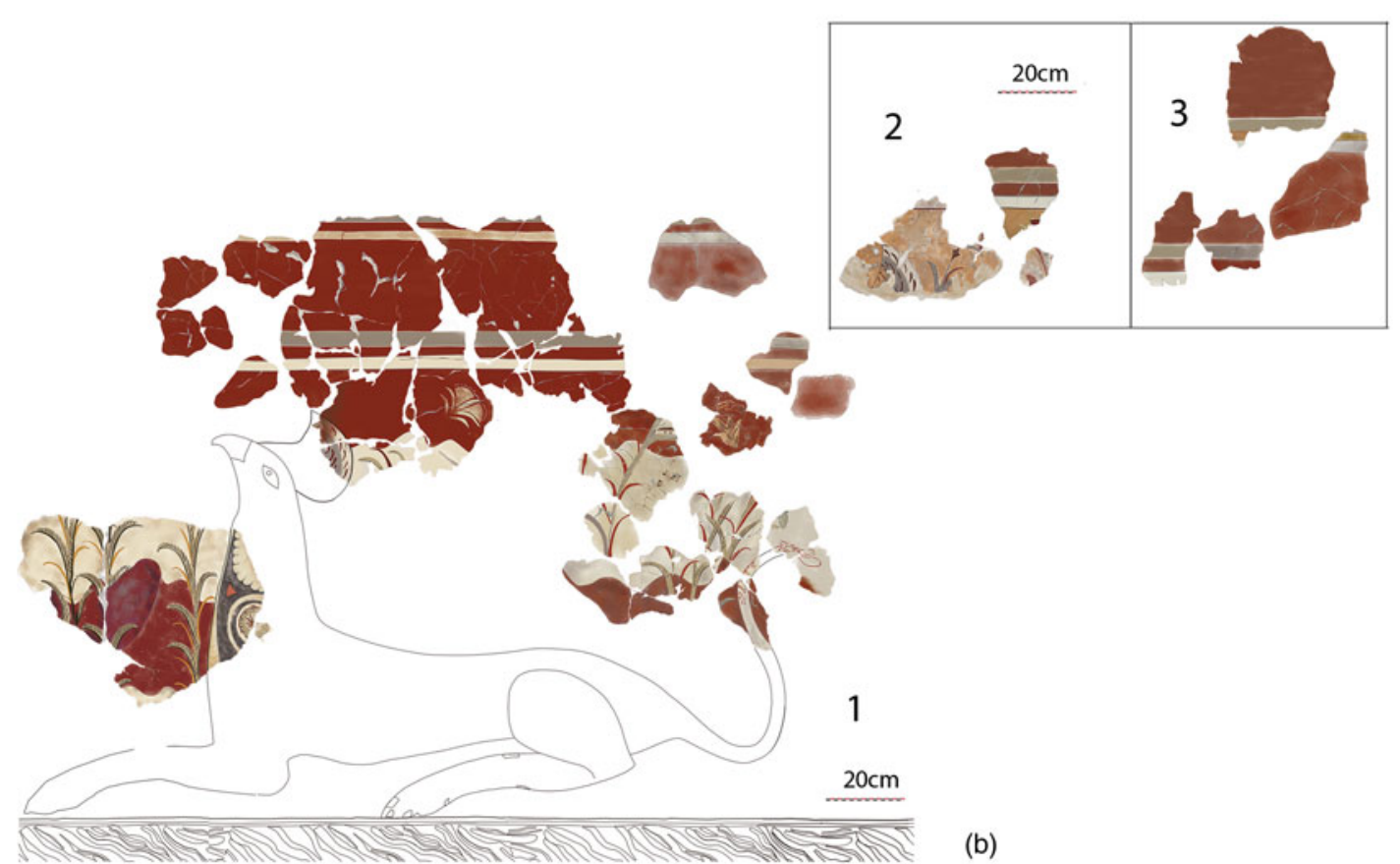

Fig. I7. (a) Drawing by Pepi Stefanaki reproducing the current state of the fragments from the north part of the west wall. Differences in the rendering of the various fragments reflect different levels of preservation. (b) I. Attempt to arrange the fragments in association with the left-facing griffin on the north part of the west wall; pieces nos 8, 9, and I5 appear to be associated with this representation, but their position in the reconstruction is conjectural. 2-3. Fragments which do not appear to belong to the north part of the west wall. Courtesy of Yannis Galanakis and Pepi Stefanaki.

The single most important fragment, from the north part of the west wall, is undoubtedly the 'crest' that can be seen at the bottom of fragment no. 7, first identified by Shank (Shank and Balas 2003, I63, pl. XLI $b$ ). In one of her reconstructions, Shank placed this fragment on the north wall of the Throne Room (Shank 2007, I64, fig. I9:4, as a crest, and fig. 19:5, as a wingtip). Yet there is no evidence that this piece ever belonged there. Instead, a close study of the archival photographs suggests to us that this fragment can actually be identified among the in situ remains on the north part of the west wall (Fig. I8 inset is identified because of its breaks as part of Fig. I7a:7, a fragment which in 1900 was still clinging on the wall). Moreover, this piece comes from the area where the third from bottom white undulating band meets the fourth and final red undulating band. Therefore, this 


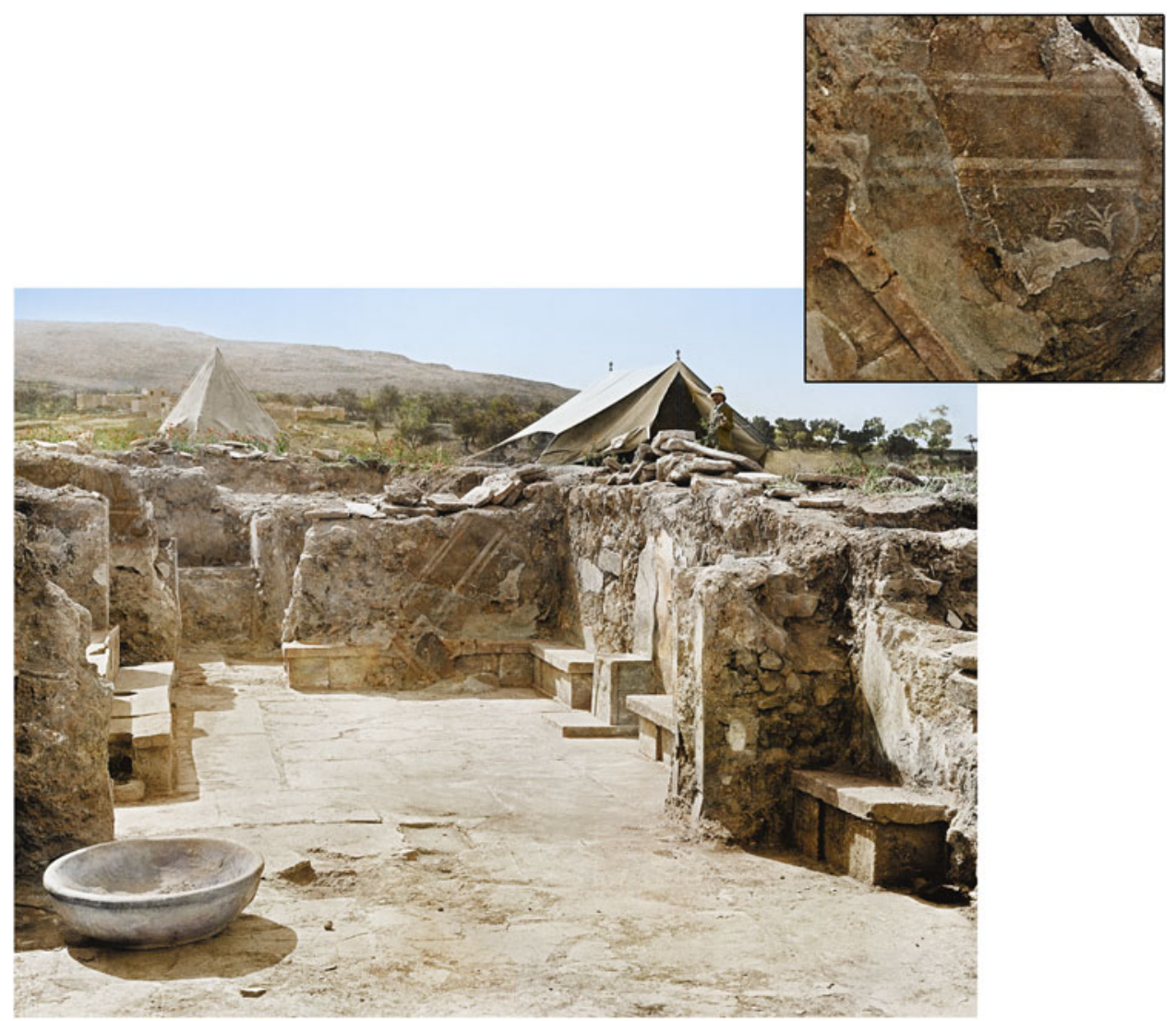

Fig. I8. Modern colourisation of PhEvans Book 8, 32, no. E.Top. 676a (= Brown 2000, fig. I9). It shows the north and west walls of the Throne Room in April 1900. Large painted fragments are clearly visible, including the reed-looking plants crowned with a papyrus-lotus arrangement (inset for detail), which today are only partially preserved. Colours on this photo are approximate only. Produced by Dynamichrome. Original photograph courtesy of the Arthur Evans Archive, Ashmolean Museum, University of Oxford.

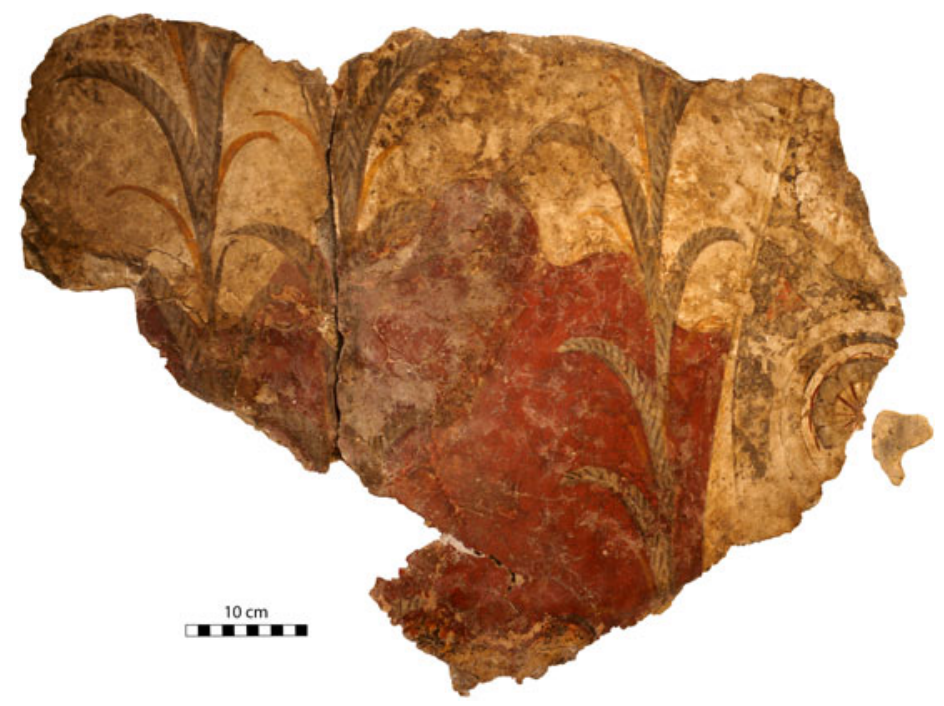

Fig. I9. Part of the griffin's chest and plants, from the north part of the west wall of the Throne Room (Fig. I7a:2I), with $10 \mathrm{~cm}$ scale. Courtesy of ҮП.ПО.А. Т.А.П. - Archaeological Museum of Herakleion, Hellenic Ministry of Culture and Sports - Archaeological Receipts Fund. 
fragment would fit perfectly with the griffin on the north part of the west wall as a raised crest (as suggested in our reconstruction: Fig. $\mathrm{I} 7 b: \mathrm{I}) .{ }^{\mathrm{I} 2}$

As part of this panel, there are also some painted fragments that do not appear to belong to this wall (Figs I7a, I $7 b: 2-$ 3). They differ from the other fragments from the north part of the west wall in that the background colour, where pictorial representation appears, is ochre not red (e.g. Fig. I7a:I0, 22-3); and that the middle horizontal band is painted in ochre instead of red (e.g. Fig. I7a:II, I3). In addition to these differences, the outer edges of the horizontal bands associated with the light ochre fragments were painted (Fig. I $7 b: 2$ ), not incised as those of the main composition (Fig. I $7 b: \mathrm{I}$ ) which could further suggest that some of these fragments come from another perhaps very similar - decorative programme, but not from the Throne Room proper. ${ }^{13}$ The top end of a 'flower' is visible in no. IO, while again the most important piece appears to be the 'crest' set on a light ochre background (Fig. I7a:22). From the few details available to us, this 'crest' - almost identical in rendering and overall layout to the two crests on the north and south part of the west wall - along with the bands and floral decoration may have belonged to a similar scene (i.e. a crested griffin set in a similarly rendered floral environment).

Cameron was the first to identify no. 22 as a 'crest' (Cameron I976, III; CAM 235, Fig. 20). He considered it part of the griffin on the east side of the throne (Fig. 9). He placed this fragment on the north wall because he thought that its background would find a better match there than on the west wall, where the upper undulating band is clearly red. $\mathrm{He}$ was of the opinion that the background - the undulating bands - somehow changed colour round the north-west corner of the Throne Room: 'for that reason', he noted, 'I have added ex hypothesi large palm trees at the W and E sides of the northern frieze so that the 'changeover' in background scheme can be distinguished', which explains the addition of more palm trees in his reconstruction (letter from Mark Cameron to Sieglinde Mirié, 4 March I972; Mark Cameron Papers, British School at Athens). If, however, the uppermost undulating band on the 'palm fresco' is red also on the north wall, as we argue here, then this fragment would fit neither on the north nor on the two parts of the west wall (Fig. 2I).

Admittedly, we do not know where the fragments with a light ochre background come from. We should not exclude the possibility that the 'crest' identified by Cameron actually comes from another floor or area of the palace, where a similar decoration appeared, and that it was included in the fragments from the north part of the west wall by mistake. A letter by Mackenzie to Evans (dated 17 November I90I) may provide us with a clue as to how these fragments were packed for transportation to the Herakleion Museum in the way they were (i.e. not always correctly): 'it became clear that there was not much use trying to fit more pieces at Knossos, and all that could be done was to take care that, in packing, pieces that belonged together should at least go into one box, if possible into one layer. So all the fresco was sent to the museum' (letter cited in Momigliano 1999, 159). Since the unconserved fragments from the north part of the west wall had already been removed in the course of the I900-I season, as suggested by the available archival photographs, it becomes clear that pieces that belonged together, or were thought to have belonged together, were stored in the same panel. The collection and storing of these fragments should thus make us extremely cautious when trying to associate the fragments with ochre background with the walls of the Throne Room. Similar decorative schemes may indeed have been present on the walls of different rooms at the same time at Knossos. We can infer this from the left-facing chest fragment of a griffin, said to be from the palace, with an almost identical design to the griffins from the Throne Room (Cameron 1976, II2, pl. I30 $A$ ).

The available archival images show numerous details now no longer preserved on the extant fragments (Fig. I8). We estimate that about 30 per cent of the fragments found in situ on the north part of the west wall are now lost (e.g. the plants on the right side of the composition are still visible in the early excavation photos for 1900 but not in the later ones of that year [e.g. PhEvans Book 8, 22, no. E.Top. 656]). Some of these lost fragments were included in Fyfe's I90I coloured reconstruction of the Throne Room $(K n D r A$ II.B/4 = Fig. 22), which was subsequently used as the basis for Lambert's 1917 drawing $(K n D r A$ II.B4a = Fig. 23). Mackenzie noted in his diary: 'the fallen fresco of the W wall showed a design of palms on a hilly ground. At the top were double grey bands at large intervals in grey on the red ground. The palms were grey on the red ground' (DM/DB I900.I, I4 April, 38). Although not 'palms' as Mackenzie thought, the two flowers clearly visible in the inset photograph in Fig. I8 are probably fragments nos I6-17 in Fig. $17 a-b$, best identified as papyrus-reed hybrids.

5 - west wall, south part: the panel with the best-preserved, crested, wingless crouching griffin in right profile, from the south side of the entrance to the 'inner sanctuary' set among floral decoration and four undulating red and white bands. This panel, smaller than when first discovered (Figs 24, 25), is today on display in the permanent exhibition of the Archaeological Museum at Herakleion ('Minoan painting' gallery). Dimensions of panel: W: $260 \mathrm{~cm} \times \mathrm{H}$ : $193 \mathrm{~cm}$. Archival and excavation references: $A E / N B$ I900, I6 and I8 April, 46-9; $D M / N B$ I900. I, I7 April, 42; KnDrA II.B/2a-d and B/2i, including a pencil sketch by Fyfe (1900); Evans I935, 9II, fig. 884

I2 The presence of a crest is considered an Aegean feature when found in Egyptian art: Morgan 2010.

I3 Shank 2003, 53, table I was the first to observe that most fragments with bands had incised outlines, while the bands that appear in association with the ochre background did not (nos. 14 and 30 according to her numbering system, and Fig. I7a:22 and Io respectively in our publication). The fragments in Fig. I7b:3 have their bands incised and it is for this reason that we cluster them together. At first glance, this may seem important for grouping these fragments separately from nos Io and 22. Yet the horizontal line under the beast's paw in the 'palm fresco' is incised, while the same line under the griffin's body on the south part of the west wall is painted only, suggesting the coexistence in the same composition of incised and painted only edges/lines. Fig. I7a:I2 and I 4 are tentatively placed in the third group (Fig. I $7 b: 3$ ); but could well be from either of the other two groups. 


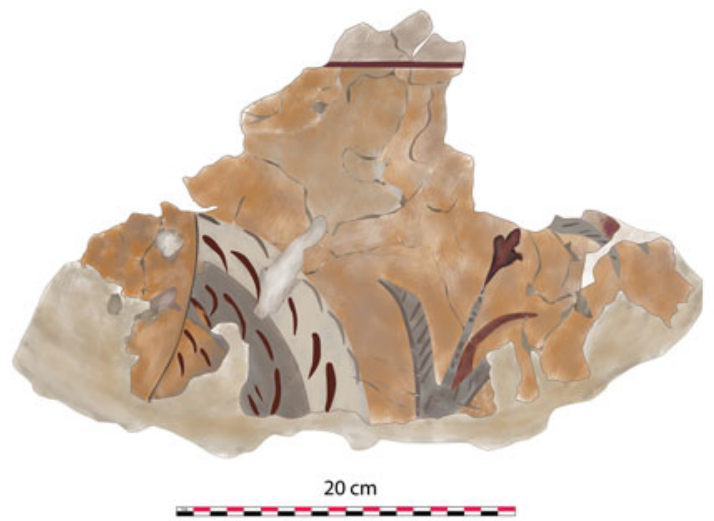

(a)

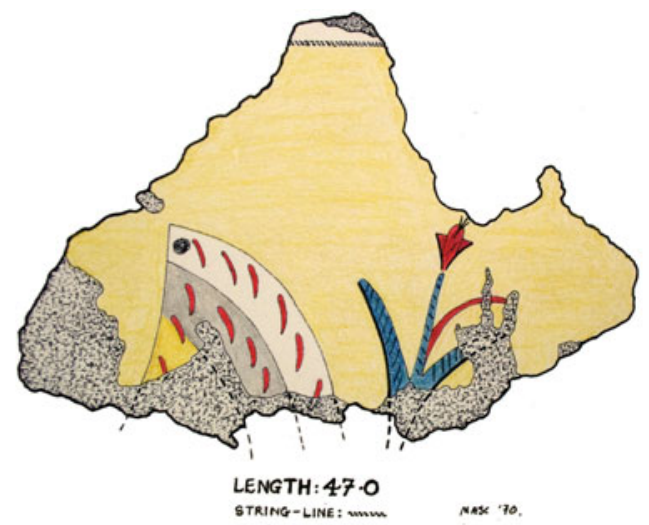

(b)

Fig. 20. (a) Drawing by Pepi Stefanaki of the crest in ochre background (Fig. I7a:22), now stored with the fragments from the north part of the west wall. Courtesy of Yannis Galanakis and Pepi Stefanaki; (b) Drawing by Mark Cameron of the same fragment (CAM 235). Courtesy of the British School at Athens.

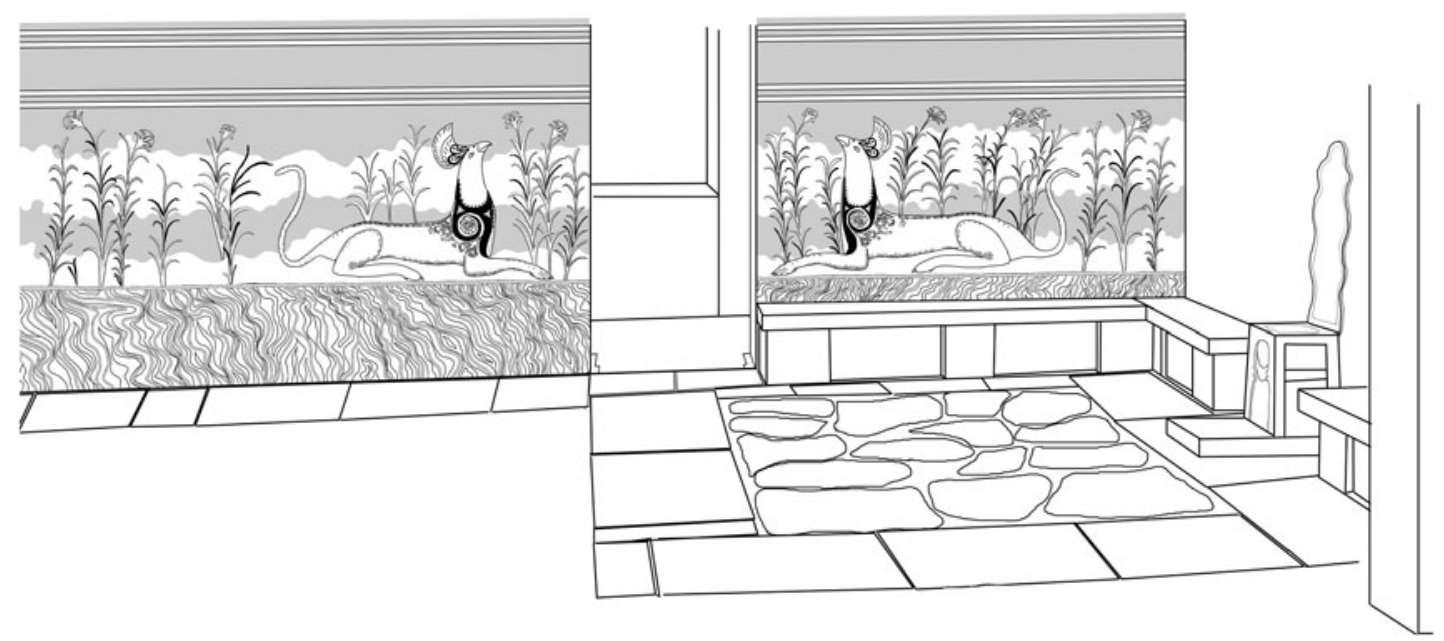

Fig. 2I. Reconstruction line drawing of the west wall of the Throne Room based on archival and archaeological data. For this reconstruction, we have assumed that the 'stone veining' in the south part of the west wall continued to the floor. Nothing is recorded as coming from the lowermost part of this wall either archaeologically or in the extant archival material (but see also Figs 22-23 for alternative suggestions). Prepared by and courtesy of Ute Günkel-Maschek.

and pl. XXXII between pp. 9I0 and 9II (not identical but very similar to the one on display); also Cameron I976, vol. 3, I09-IO, pl. I27.

Two registers of white and red bands from the uppermost part of the wall are partially preserved in this panel. The tail of the griffin and the lowermost part of the crest are also partially preserved. The crest was possibly raised, not least as the fragment immediately to the left in the present restoration (where the crest would have continued) does not belong there but in another area of the composition (i.e. leaving space for a raised crest to appear as shown in the original excavation drawings). ${ }^{\mathrm{I}}$ The front part of the neck and front paw are not preserved. A red line, painted freehand (again, not very straight) and with no traces of incisions or rope marks, separates the upper part of this fresco from the lower part where the 'veined stone' dado decoration appears.

In contrast to the image now adorning the Throne Room at Knossos, this griffin - from which all other Throne Room griffins are modelled - does not have outer pendent curl-tip 'plumes' on the neck (contra Evans I935, 910, who is clearly

I4 Fyfe's colour drawing and Gilliéron's first draft of this griffin, as well as the Ashmolean archival pictures, support further the suggestion put forward here that this small fragment was misplaced there. 


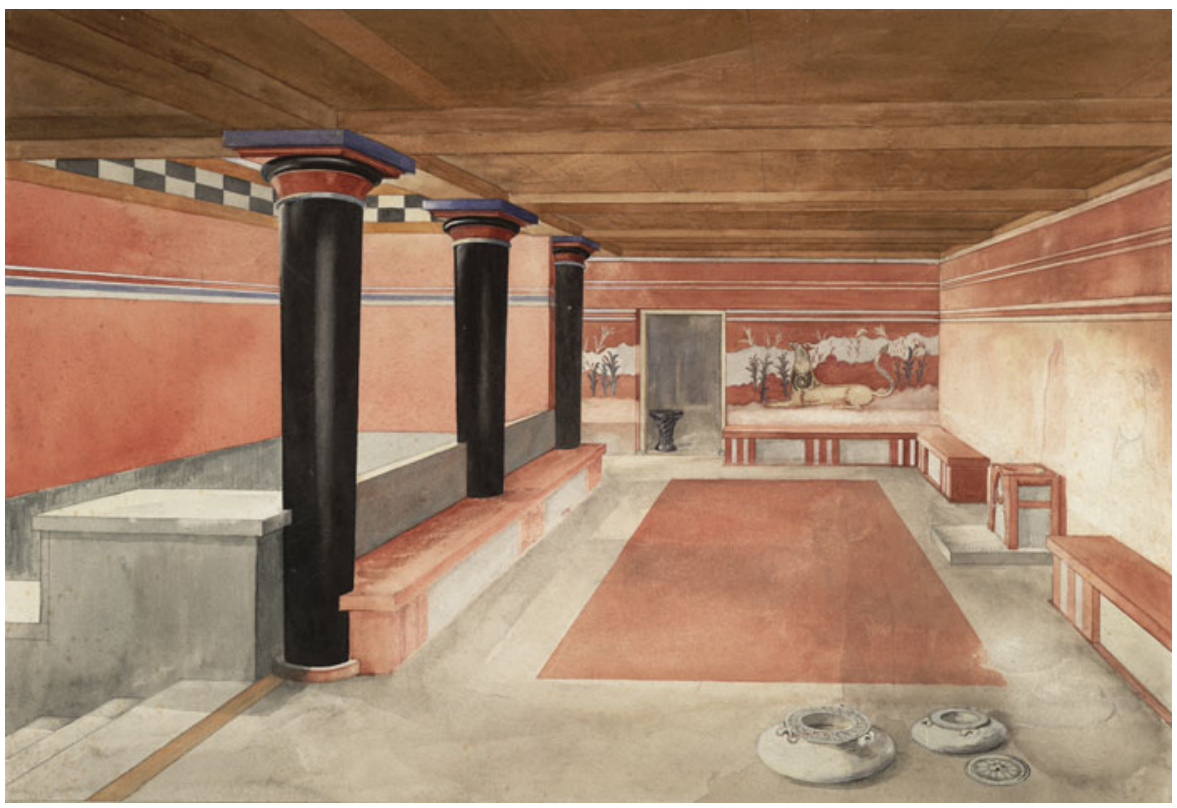

Fig. 22. Colour reconstruction of the Throne Room by Theodore Fyfe, I90I (KnDrA II.B/4). This drawing formed the basis for Lambert's I9I7 drawing (Fig. 23 here). W: $55 \mathrm{~cm} \times \mathrm{H}: 4 \mathrm{I}$ $\mathrm{cm}$. Courtesy of the Arthur Evans Archive, Ashmolean Museum, University of Oxford.

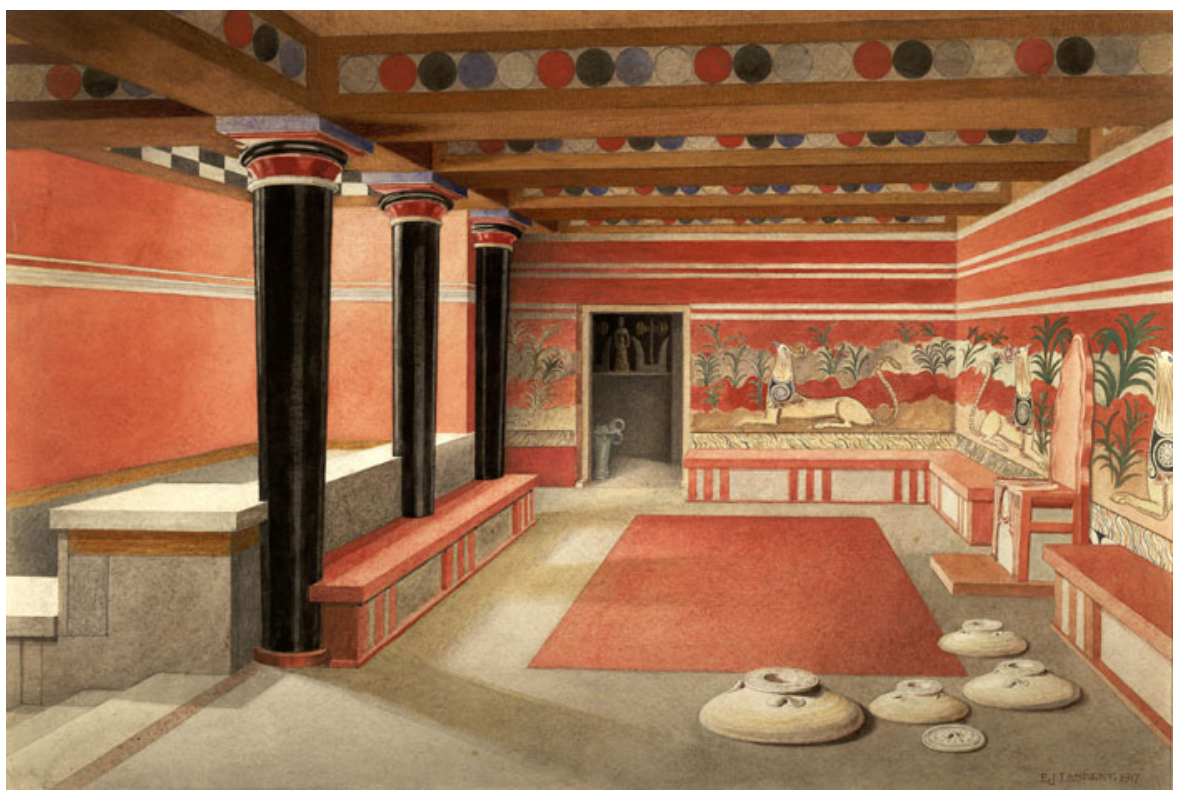

Fig. 23. Edwin Lambert's 1917 colour reconstruction of the Throne Room $(K n D r A$ II.A/7 $=$ Evans 1935, vol. 2, frontispiece). W: $56 \mathrm{~cm} \times \mathrm{H}: 38 \mathrm{~cm}$. Courtesy of the Arthur Evans Archive, Ashmolean Museum, University of Oxford.

describing Gilliéron's drawing [pl. XXXII] rather than the actual fresco fragments, e.g. compare Figs 24, 25, 26)..$^{15}$ Additionally, the ghosts of two thin papyrus flowers are today barely visible on top of the plant in front of the griffin, and another similar group may have existed further to the right, judging by Fyfe's drawing (Fig. 24). These flowers were probably combined with a lotus, similar to the arrangement known from the north part of the west wall, the

I5 Evans thought that the plumes 'are seen to curve round an inner scroll formed of the "waz", or sacral papyrus wand, between two spirals'. Lambert's reconstruction (Evans 1935, frontispiece [pl. XXXIII]), based on Fyfe's original I 900 drawings, depicts the body of the griffin more accurately than all later reconstructions. 


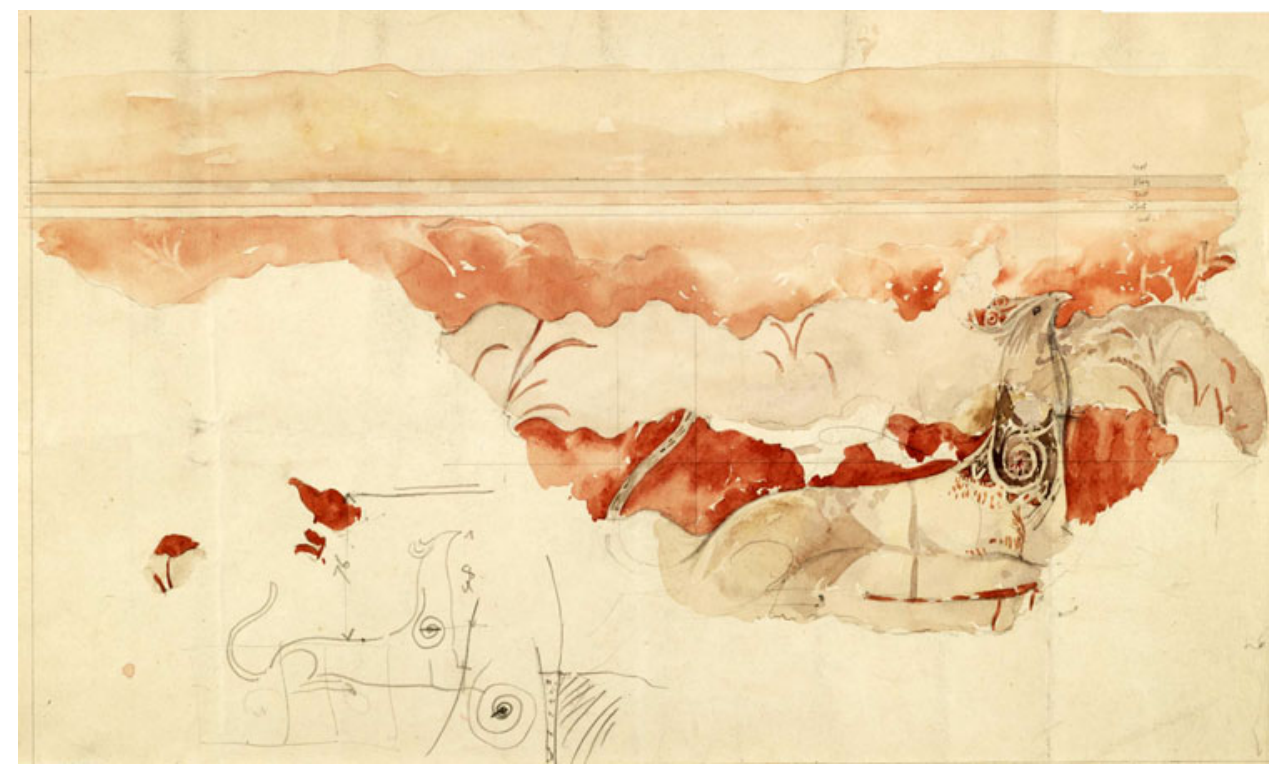

Fig. 24. The best-preserved of the Throne Room griffins from the south part of the west wall in a watercolour drawing, probably by Theodore Fyfe, c.I900. KnDrA II.B/2a. Courtesy of the Arthur Evans Archive, Ashmolean Museum, University of Oxford.

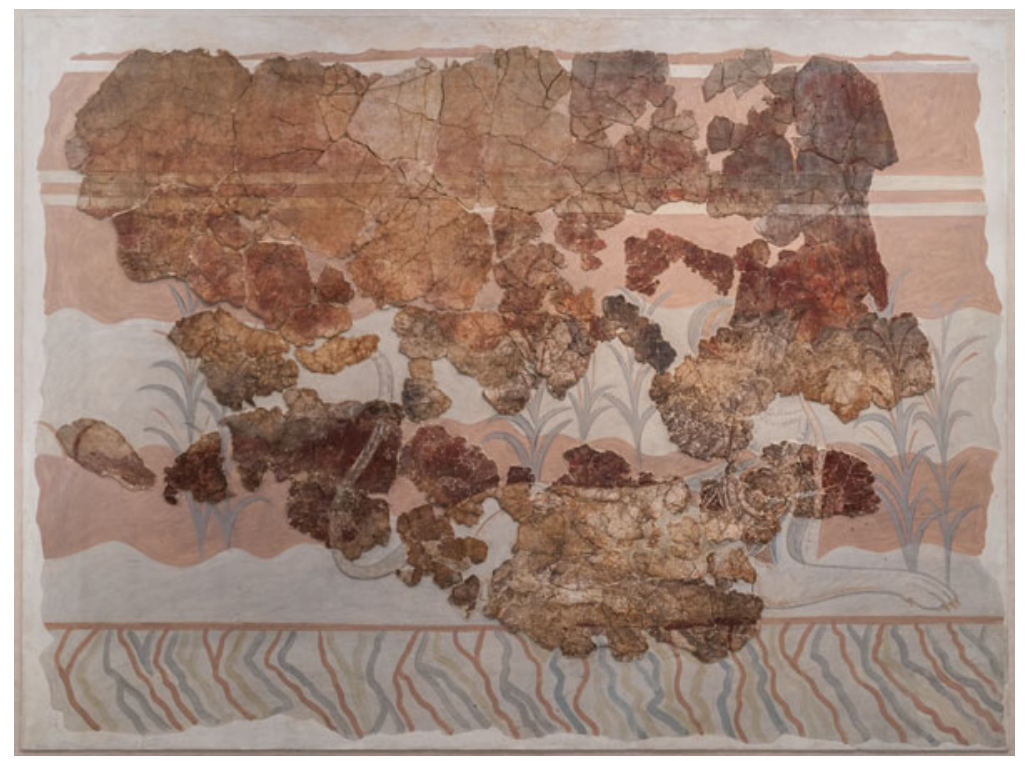

Fig. 25. The best-preserved of the Throne Room griffins as displayed at Herakleion. Courtesy of ҮП.ПО.А. Т.А.П. - Archaeological Museum of Herakleion, Hellenic Ministry of Culture and Sports - Archaeological Receipts Fund.

north-east corner and the south end of the west wall. The Gilliérons in both the 19I3 and I930 restorations used only single papyrus flowers for crowning some of the plants in the Throne Room. More noticeable differences between the Gilliérons' work and the original fragments include the thickness of the neck of the beast - thinner rather than thicker as shown on the reconstruction - and the number of flowers in front of the beast - three instead of two that appear in the Throne Room restoration. As suggested by the archival drawing (Fig. 24), this fresco preserved more fragments at the time of excavation than it does today. At the left side and at the back of the griffin, some kind of fern plant (most likely a hybridised papyrus-lotus flower) was preserved, in a similar position to the plants on the north part of the west wall, and also on the north-east wall mentioned above (Figs 7, I7b).

On the opposite side, on the east wall of the corridor, more plaster fragments were preserved in situ. Nothing is mentioned about these fragments in the archives or the published reports. We assume that they might have been 


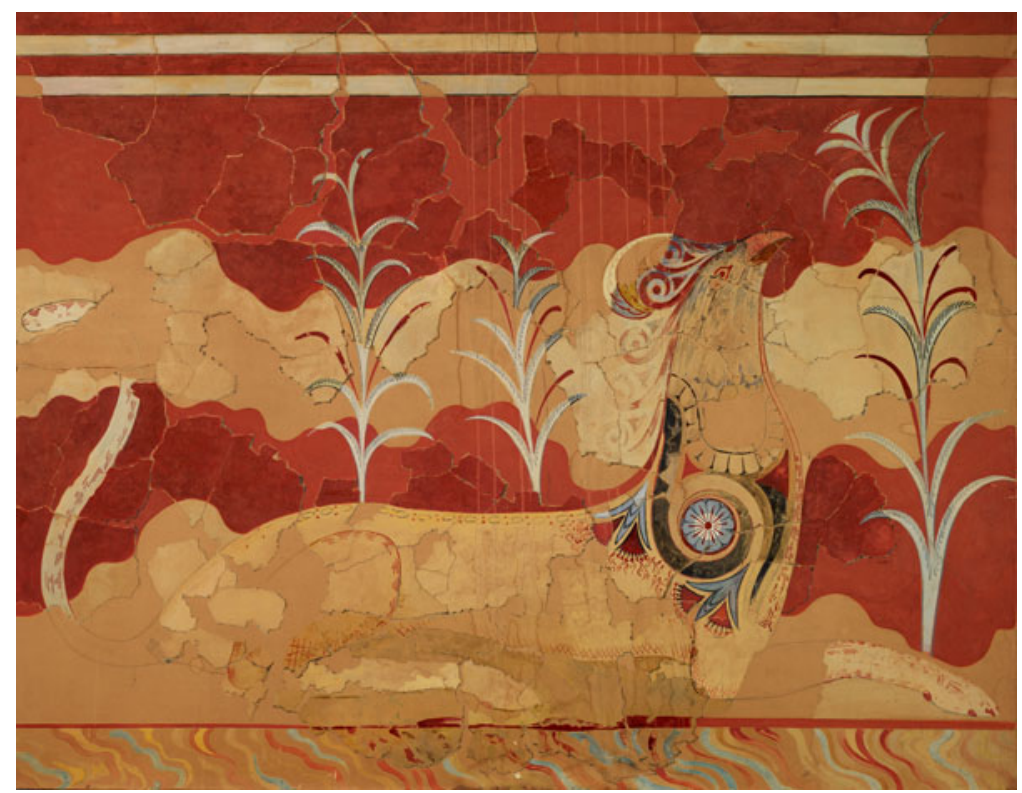

Fig. 26. Watercolour drawing of the best-preserved griffin from the south part of the west wall of the Throne Room at Knossos, possibly by Gilliéron, the younger. $\mathrm{KnDrA}$ II.B2/i $=$ Evans 1935, col. pl. XXXII. W: $87 \mathrm{~cm} \times \mathrm{H}: 70 \mathrm{~cm}$. Courtesy of the Arthur Evans Archive, Ashmolean Museum, University of Oxford.

painted plain red with bands at the top, similar to the lustral basin (a fragment still clinging on the wall visible in PhEvans Book 8, 29, no. E.Top. 663A = Evans I935, suppl. pl. LXIII).

6 - Lustral basin (Figs 8, 22): various large fragments from the area of the basin. These fragments are still preserved in situ, mainly on the west and south parts and to a lesser extent on the east wall of the basin. Archival reference: $\mathrm{Kn} \operatorname{DrA} \mathrm{I} . \mathrm{WW} / 8$. No mention of the lustral basin's decoration is made in the excavation notebooks.

The walls were painted red, bearing at the top two registers of white/grey and red bands (also Evans I935, 908-9, fig. 883). These fragments are visible in numerous archival photographs in the Arthur Evans Archive and on Fyfe's I900 section drawing.

\section{A Note on the Paint Layers and Techniques}

As part of the conservation process, the application of macroscopic analysis and Raman spectroscopy provided us with more detailed insights regarding the painting techniques used in the creation of the Throne Room fresco. Our study confirmed Evans's view that all paintings were 'painted on a very thin coating of stucco laid direct on the mud and rubble surface' of the wall $(A E / N B$ I900, I8 April, 49). It is worth noting that our attempt to describe the paint layers and techniques used in the Throne Room decoration is hindered by considerable paint loss in various areas of the wall paintings and also by their original restoration by the Gilliérons. Furthermore, it was not possible examine the layers of the lime plaster in a non-destructive way because all the fragments from the Throne Room have been boxed in a new substrate with plaster of Paris since I900-I. Despite these shortcomings, a number of observations can be made regarding the paint layers of the 'palm fresco' and the techniques used in its making.

The creation of the paint layers began with the preparation of the wall surfaces around the benches and throne. The surface of the masonry was covered initially with a layer of mud plaster containing impurities and plant fibres. The next step involved the application of a coarser plaster, which was followed by a fine-powder plaster: it was on this final plaster that the coloured composition was created. In all these layers, lime (calcium hydroxide) was used as the binding material. Around the throne, the plaster followed carefully the contours of the stone seat (Figs I, 4, I6), incorporating it seamlessly in the composition (i.e. throne and fresco forming an indivisible whole). 
After completing the application of the lime plaster, the artists initially defined the area of the composition within which they would paint. On the still-wet final layer, they created with a thin string the horizontal lines of the bands on the upper part of the walls. In the section between the throne and the bench, the artists did not use a string but a sharp tool to engrave a (freehand) guideline. In the next step, this line was covered by red pigment. This red line therefore helped divide the composition into an upper and lower section, the former including the griffins and plants and the latter the imitation of 'veined stone' and, in the case of the throne, the 'altar'. Having defined these two sections, the artists created a draft design of the composition on the wet plaster. In areas where paint loss can be observed, this draft design is still visible with the naked eye: for example, on the 'altar' by the throne and beneath the white impasto a red-orange colour which was originally applied as a guideline can still be seen.

The application of pigments was done in layers. The red undulating bands were the first to be painted on the upper section (the red identified as hematite $\mathrm{Fe}_{2} \mathrm{O}_{3}$, Fig. I5:I4). The white undulating bands are simply the final lime plaster, and thus the calcite $\mathrm{CaCO}_{3}$ that remains visible (Fig. 15:15). At this stage, the red pigment was also added to the 'altar' and the grey pigment in the altar's two 'semicircles' (the areas analysed with Raman [Fig. I5:II-I2] yielded carbon black for the pigment used there). Although conjectural, it was possibly at this same time that the 'veined stone' was painted, as wet plaster was required for its creation. Employing a freehand technique, the artists created the colourful veins, having at their disposal only three colours (red, ochre, black). With a brush, they applied each pigment onto the fresh white plaster using different proportions of binder and pigment to change the volume and tone of each stroke.

Special care was taken in making the palm tree. The artist(s) made an effort to distinguish the palm's red trunk and red leaves from the red background of the undulating bands: they applied yellow ochre to the lower part of the tree, making it even more distinguishable, while for the red leaves they achieved a different tone from the one that appears in the undulating red background. They therefore display a good, practical, grasp that a powder of different particle-size distribution results in marked differences in tonality. They probably used ochre in combination with red in an attempt to render the leaves in a different tone of red from the dark red of the undulating background. To make sure that the palm's trunk and its leaves would stand out clearly from their background, the artist(s) outlined them with impasto white dots, creating a distinct dotted line. Impasto white dots were also used on the dates, three dots for every fruit. Despite the bad preservation of the leaves, we are of the opinion that the red of the palm was added either completely on top of the red undulating background or at least partially (e.g. a red outline was first painted for the leaves, only for them to be filled shortly after with a different tonal red pigment from the undulating background). A white impasto line was also painted on the upper part of the lowermost undulating band.

Raman spectroscopy on the 'palm fresco' was carried out by the Institute of Electronic Structure and Laser of the Foundation for Research and Technology Hellas (IESL-FORTH) at Herakleion. The complete characterisation of pigments with a portable Raman was limited because of the existence of a thick varnish layer from previous restorations. Raman, as a non-destructive technique, can detect only the surface of a material. The varnish resulted in very strong fluorescence emission which on most spots blocked the creation of Raman spectra, preventing the detection of the chemical type of pigments. Although we tried to characterise the difference between these two red pigments (leaves and background), after several trials on different spots we were able to detect only hematite $\left(\mathrm{Fe}_{2} \mathrm{O}_{3}\right)$ by the Raman spectroscopy (see e.g. Fig. I5:5, 7, 9, I4).

On the second painted layer, the griffins were created with white impasto. On the 'palm fresco', in particular, the use of impasto is observed on the animal's paw and on the frame of the 'altar'. All the details of the griffins were created on this white layer (e.g. the red nails, the use of cross-hatching and s-shaped lines on the body of the beasts, the decoration on the chest and the details on the crests). The plants were also painted on top of the bicolour background (i.e. white and red undulating bands). The final brushstrokes on the plants were the black parallel lines ('veining') on the grey leaves and the details of the flowers (e.g. the orange or red smaller leaves).

To sum up, four pigments were used for the painting of the Throne Room's decoration: (I) white plaster (calcite $\mathrm{CaCO}_{3}$ lime), attested in the horizontal bands, the body of the griffins, the white background (which formed part of the undulating bands), the 'altar' and the crests; 
(2) carbon black, attested in the area of the 'altar', in the plants, in the decoration of the griffin's body, in part of the crest and as an outline for one of the horizontal decorative bands on the upper part of the wall; (3) red (hematite, $\mathrm{Fe}_{2} \mathrm{O}_{3}$ ) - the most dominant colour in the Throne Room - which is attested in the decoration of the griffin's body, the undulating bands, the palm, the crests, the smaller plant leaves and the 'veined stone'; and (4) ochre/yellow (unidentified pigment), as attested in the 'veined stone', some of the small plant leaves, the cross-hatching on the griffins' bodies and also in the crest set in an ochre background (Fig. 20). The lowermost undulating band, which appears to the naked eyed more grey than white (especially in the 'palm fresco' and the best-preserved griffin from the south part of the west wall), was in all likelihood originally white, a point further supported by the small fragment preserved with the griffin from the north part of the west wall (Fig. I9).

\section{A BRIEF HISTORIOGRAPHY OF POST-EXCAVATION RECONSTRUCTIONS}

There have been three major phases in the reconstruction of the decorative programme of the Throne Room: the first belongs to Arthur Evans and his artists, the second to Mark Cameron and the most recent to Elizabeth Shank.

Evans's attempt to reconstruct the decorative programme has numerous iterations, on paper and more concretely on the walls of the Throne Room. The process of reconstruction started as early as 1900, as Fyfe's archaeological drawings suggest. Fyfe accurately presents the state of excavation (Fig. 8). In I90I, he produced another drawing - a coloured reconstruction this time (Fig. 22) - which was subsequently used as the basis for Edwin Lambert's famous I9I7 drawing (Fig. 23). Unlike Fyfe's drawings, however, Lambert's illustration has several problems in the rendering of the floral elements and the absence of the 'palm fresco' to the right of the throne. This absence is actually the most problematic element in Evans's reconstructions.

Should we explain Evans's neglect of the 'palm fresco' as a result of his unreliable memory, or was this painting out of sequence, so to speak, in his scheme of the evolutionary development of artistic motifs? There are many reasons why this particular painting might have been overlooked, and there is indeed something intriguing about Evans's 'partial' memory. For example, his notes in the second volume of The Palace of Minos preserve a vague reference to the 'palm fresco' without Evans putting his finger on it:

It is a fair conclusion that a group of palm-trees on a knoll or slight elevation ... answered to some painted plaster design, decorative in form but perhaps essentially of a religious character, that filled a prominent place on the Palace walls. (Evans I928, 494)

Both in his publication and in the restoration of the fresco on the walls of the Throne Room, Evans and his restorers decided to 'forget' what was actually found in situ. There are a couple of hints that may provide an answer to this puzzle. The first comes from Evans's excavation notebook just two days after the discovery of the 'palm fresco'. On Saturday I4 April 1900, he made the following note:

Further excavation of bathroom showed another bench symmetrically balancing that on the other side of the seat of honour and another frescoed wall along W side of room. The fresco proves not in any case to be palms but to represent a kind of reed and a flowering rush. There is the usual Mycenaean arrangement - also Egyptian - of the hills of the landscape coming down from the upper as well as the lower border. ( $A E / N B$ I900, I4 April, 38-9; our italics)

This extract is particularly telling about Evans's interest in the symmetrical balance of the composition, ${ }^{16}$ the lack of palm tree representations on the west wall and the possible

I6 Evans was convinced as early as 1902 that two griffins stood on either side of the throne $(A E / N B$ I902, no date, I7). 
'Mycenaean' (as he thought back then) and 'Egyptian' influences. It is even more telling when compared to Mackenzie's observations of the west wall and on the same day:

Above the part of the seat which runs N-S large pieces of wall-painting came into view. The dado slanted in such a way as to show at once that the fresco had slipped down from its original position on the wall (and) on to the seat and floor. The fallen fresco showed a design of palm trees and other plants and flowers in a hilly landscape, the palms appearing grey ${ }^{17}$ on the red ground. (DM/NB I900.I, I4 April, 28)

It appears that Evans was already following a different line of thinking to Mackenzie in terms of the composition of the Throne Room's decoration and of the significance of the various elements that appeared on it. This discrepancy becomes even more baffling when a few days later and in his preliminary report he does mention 'a kind of fern palm' and 'tree ferns or palms' on the south part of the west wall and in association with the best-preserved griffin (e.g. $A E / N B$ I900, I6 and I8 April, 46-7). In his preliminary report (Evans I899-1900, 40), he mentions rushes and sedgelike plants with red flowers, and that 'at one point rises a palm tree and on the landscape continuation on the western wall a fern palm was carefully delineated'.

Another hint, for Evans's 'absent-mindedness' - if it can be described as such - and the progressive 'disappearance' of the palm tree from discussion on the Throne Room, may be included in the following description of the Throne Room fresco in the last volume of The Palace of Minos:

A pair of good examples of these [altar-bases] in relief combine to support the baetylic column, and the fore-feet of the two lions of the Mycenae gateway. A striking religious parallel indeed is here presented by the altar-base as thus depicted beside the throne and the semi-divine personage that once occupied it ... This aspect of the throne as forming the centre of a religious composition is well brought out in the photographic view (fig. 895) ... with the painted stucco designs on its walls as restored, showing on either side of it the altar-bases and confronted Griffins. (Evans 1935, 919-20)

We would argue that Evans's main focus of attention in the Throne Room composition was on its religious nature (the 'altar-base') and on the antithetic scheme (his 'Lions' Gate scheme') - a scheme that he had in mind as early as 190I, if not earlier (Harlan 20II), as shown by the discussion of some lentoid seals with antithetical representations and of the Lion Gate at Mycenae as part of his work on the 'Mycenaean tree and pillar cult' that formed the basis of his concept of Minoan religion (Evans I9OI, I56-69). Having the picture of 'griffin supporters' of a central divinity in mind, the palm in the Throne Room literally stood in the way between the griffins and the throne. So, in contrast to the griffin and the 'altar-base', which both belonged to the cycle of heraldic compositions framing a divinity or sacred object in the 'Lions' Gate scheme', Evans omitted the palm in the 'reconstitution' of the Throne Room - his attempt to create an image as impressive as the Lion Gate at Mycenae, with the occupant and throne taking the place of the divinity (Evans I90I, I5I).

This idea of recreating, and immersing himself in a 'living world', is why, we suspect, Evans does not seem to have been at all worried by some of the Gilliérons' more imaginative reconstructions, or to have noticed the obvious contradictions or anomalies in the vegetation on the Throne Room fresco. To Evans, the Gilliérons' reconstructions could not be 'wrong' in any meaningful sense, since they were merely what his informed imagination led him to believe must have, or ought to have, been there. They filled in the gaps, and made his increasingly idealised civilisation more complete and more real (Sherratt and Galanakis, forthcoming). As a result, the restorations by the Gilliérons in I9I3 and I930 ignored the 'palm fresco' and established a balanced composition in the Throne Room - one that has become emblematic ever since.

${ }^{17}$ Mackenzie is referring here to the papyrus-lotus arrangement seen in Fig. I8, inset. 
Mark Cameron's detailed study of the fragments from the Throne Room offered the next major attempt to reconstruct its decorative programme. Cameron was the first to reintroduce the 'palm fresco' into the room's iconography (Cameron 1976; 1987; and his unpublished notes in the BSA archives). The placement of the crest in ochre background - one of the fragments from the panel associated with the north side of the west wall, as mentioned above - with the griffin to the right of the throne, made Cameron change the colour scheme of the undulating bands and add palm trees in either end of the north wall in an attempt to explain the colour transition of the bands. Our analysis, however, apart from clarifying details on the 'palm fresco', also suggests that the colour scheme of the undulating bands was, in all likelihood, consistent on all three walls where iconography appears. This scheme is probably the most secure element in the restorations of Fyfe, Lambert and the Gilliérons, and the crest in ochre should therefore be dissociated from the north wall's decorative programme (for the various restorations of the Throne Room paintings see Evely I999, 56-9, 65 and 202-3).

The most recent attempt to establish in detail the Throne Room's iconography stems from the work of Elizabeth Shank and her careful study of the fragments from the north side of the west wall (Shank 2003; 2007; Shank and Balas 2003). Following Cameron's steps, Shank identified a second 'crest' among these fragments: this second 'crest' was set on a red background, not ochre as is the case with Cameron's fragment. Following her discovery, Shank put forward two interpretations: that this fragment showed either a raised crest or a wingtip (on the latter see Shank 2003, I32-7; Shank 2007, I62-4, fig. I9:5; also Blakolmer 201 I). ${ }^{18}$

The winglessness of these beasts was actually noted as 'an unique peculiarity' as early as 1900 (Evans I899-I900, 40), and it remains so: in a corpus of more than 330 examples (Zouzoula 2007), wingless griffins in Aegean art are extremely rare. ${ }^{19}$ Yet enough remains from the best-preserved griffin on the south part of the west wall (Fig. 24) to ascertain its winglessness. The striking similarity in the rendering of the body between this griffin and the one on the north part of the west wall suggest to us that both beasts were wingless. Although it is speculative whether the beast(s) on the north wall was/were also wingless, we note the complete lack of any other fragment indicating the presence of a wing from the corpus of extant fresco fragments from the Throne Room at Knossos. Moreover, the two 'crests' match perfectly - in decoration, overall arrangement and artistic details - with the lowermost part of the crest from the best-preserved griffin on the south part of the west wall. Griffin wings are most often rendered differently from crests (e.g. Cameron 1976, vol. 2, pl. I3I $A-K$, vol. 3, II3-I4). The Throne Room 'crest' fragments also find iconographic parallels in a number of examples showing raised crests, including the Ayia Triada sarcophagus (Long I974, pl. II, fig. 26) and the Menidi and Kazarma seals (CMS I, no. 389 and CMS V, no. 583).

The two 'crests' that are preserved on the west wall (north and south parts) appear to be equidistant from the lowermost band that decorates the upper part of that wall. The presence of the band and of hybrid papyri or flowers near the two 'crests' confirms their orientation and approximate height in the wall composition even if one of them (the one set on an ochre background) may not actually come from the north part of the west wall. Their placement in the composition could therefore potentially correspond to the area where one might have expected a crest to end, not least as in the best-preserved griffin (south part, west wall) only the lowermost part of the crest is actually original.

To sum up: what everyone has imagined on the walls of the Throne Room as a result of successive reconstructions was not what was there originally or even what was discovered in

\footnotetext{
I8 A crested bird is the only other possibility here. Rare as they are, birds do appear in Aegean art (e.g. the Partridge and Hoopoe frieze from Caravanserai [Evans I928, IIO-I2] and the bird associated with the lyre player from the Pylian Throne Room [Lang I969, 79-80, no. $43 \mathrm{H} \mathrm{6]}$ ). But there is no other evidence to suggest that there were any birds at all in the Knossos Throne Room composition.

I9 Although the griffins from Knossos are most commonly compared to those in Hall 46 and the megaron at Pylos, it suffices to say here that the arrangement of the latter is different and more complex than the Knossian decorative programme. A comparison of the two programmes would indeed be desirable, but it lies beyond the scope of this paper.
} 


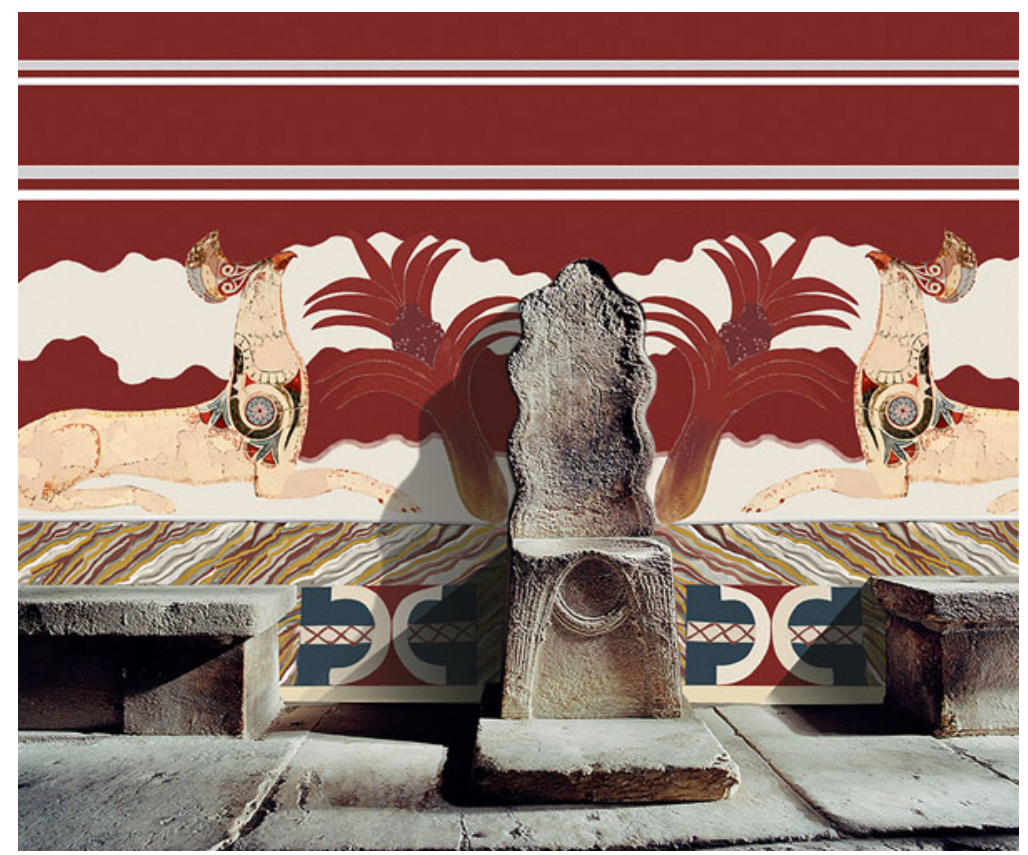

Fig. 27. Photomontage of the north wall of the Throne Room. Prepared by and courtesy of Ute Günkel-Maschek.

1900. Evans and his team found larger painted fragments with parts now missing: from the 'palm fresco', the 'veined stone' dado from the left of the throne, and also part of the painted decoration discovered on the north and south parts of the west wall. Set within an undulating ground of alternating red and plain off-white bands, the decoration of the Throne Room showed crouching griffins on the east part of the north wall and on the north and south parts of the west wall (Figs $2 \mathrm{I}, 27)$. The beasts on the west wall were wingless and most likely had upright crests. They were surrounded by a thicket of reed-looking plants (also referred to here as 'papyrus-reed hybrids'), ${ }^{20}$ with light blue-grey stems and occasionally a dark-grey outline and veining (Fig. I9). Some of the plants have yellow or red leaflets and red buds ${ }^{21}$ and appear to be flowerless, while others are crowned with a papyrus-lotus arrangement, similar to the one that appears on the body of the griffins (Figs 7, I7b, 18, 21).

A palm was placed on at least one side of the throne on the north wall, to the right of the viewer. The crown of the fruit-bearing palm appears to grow out of the trunk, starting with a lower group of three thick and arched branches, followed above by a cluster of fruits (Fig. II). The cluster is topped by another group of three thick - but less arched - leaves growing on either side. The leaf bud, usually growing from the midst of the tree, is not preserved but can be reconstructed based on Fyfe's section drawing. The particular rendering of the leaves and fruits will offer a good starting point to assess the artistic tradition to which the palm in the Throne Room fresco adhered (more below).

A 'veined stone' dado adorned the lower section of the south part of the west wall and also the north wall and the north-east corner. The direction of the 'veins' is not consistent in all walls and is

\footnotetext{
20 They are 'hybrid' in the sense that the stem resembles a reed, but in a number of examples the crown is an inflorescent papyrus-lotus flower. Although these 'reeds' bear some similarity to the 'reed bed fresco' from Akrotiri (Vlachopoulos 2000), they also find good parallels in the papyrus-reed plants that appear in the MM IIIB LM IA 'birds and monkeys' frieze from the 'House of Frescoes', room Q, at Knossos (Cameron I968; Shank 2003, 9I-2). On papyrus and its artistic hybrids see Morgan I988, 2 I-4.

${ }^{21}$ The Cyperus palm (Cyperus papyrus L.) appears to have grown locally (Warren I976) and the tall reeds such as Arundo donax and Phragmites communis are also locally attested (Morgan I988, 20).
} 
different from that shown on all available reconstructions. Yet this 'veined stone' dado pattern probably adorned all the walls in the Throne Room which bore figural decoration on the upper section. An incurved 'altar-base' was painted on the right side of the throne (Fig. II). The conservation work on the relevant fragment of wall painting has led to the unquestionable identification of the depicted object as an 'altar-base', and refutes a possible ambiguity intended by Cretan artists in rendering a shape similar to both altar-bases and friezes of 'half rosettes' (Reusch I958, 349-5I; Niemeier 1986, 84-5; also Evans 1928, 607-8). However, the existence of a similar 'altar-base' on the left side of the throne is speculative, as no remains were found there during the I900 excavation.

Our conservation and analysis of the available painted fragments, in close juxtaposition to the extant archival information, has helped clarify a number of details which appear to have been misunderstood by the Gilliérons in their reconstructions (on paper and at Knossos): for example, the decoration on the body of the griffin, the thickness of the neck of the beast, and the flora in the Throne Room. Furthermore, a number of the fragments now stored together as coming from the north part of the west wall do not appear to belong to this wall (nos IO-I4 and 22-3), as already noted by Cameron (1976) and corroborated further by Shank's study (2003). In the following section, we try to establish the place of the Throne Room decoration in the history of Cretan imagery.

\section{ARCHAEOLOGICAL AND STYLISTIC ANALYSIS}

The archaeological investigation in the Throne Room area carried out by Vasso Fotou and Doniert Evely under the direction of Sinclair Hood in 1987 concentrated on rooms $44-8$ to the north and west of the Throne Room (as reported in Catling 1987-8, 68; Fotou and Evely forthcoming). ${ }^{22}$ This investigation touched upon the north and west walls of the Throne Room, examined from the side of rooms 47, 48, 44 and 44a (Fig. 2). The soundings made there suggest with confidence that the north and west walls of the Throne Room were built from bottom up at the beginning of what the excavators call 'Period III', which they date at present to LM II. The decoration of the Throne Room, as it can be reconstructed from the extant fragments, could therefore have been either contemporary with the remodelling documented in the area - and if that was indeed the case, it lasted up to the final destruction of the palace - or done in the course of Period III of Fotou and Evely, replacing another revetment which did not leave any trace. Stylistically, we consider a LM II date for the execution of the Throne Room's decoration highly possible. ${ }^{23}$

It is worth noting that the lime plaster that covered the walls and floors of rooms $44^{-8}$ had been repeatedly renewed (the new layers were laid over the old ones). ${ }^{24}$ The 1987 investigation also showed, contra Mirié (1979) and all published plans since, that there was never a door between rooms 44 and 45 (Fotou and Evely forthcoming; mention is also made in Goodison 200I, I82). Rooms 44 and 44a formed part of a unit in LM II with the Throne Room, the lustral basin (rooms 42-3) and the anteroom (room 4I), with no direct connection to the Service Section (Fig. 3). What is less clear is whether the door at the end of the corridor to the west of the lustral basin, where the best-preserved griffin was discovered, gave access to room 38 ('MM III Room with

\footnotetext{
22 We would like to thank Vasso Fotou and Doniert Evely for sharing with us their data in advance of their publication (pers. comm., 6 November 2015).

23 Evans (1935, 909-13), Cameron (1976, 679) and Hood $(2005,65$, no. 8) favoured a LM II date for the Throne Room decoration. Immerwahr (I990, 96-8, I76, KN No. 28) preferred a LM II-IIIAI date.

24 Evans's observation (I899-I900, 36, 38, 54) of remains of lime plaster on the flagging of the Throne Room and the Anteroom compels us to admit that red painted and white lime plaster formed the latest floor of these two spaces. Cameron also explained in a letter to Miriè (4 March and 20 June 1972, letters from M. Cameron to S. Miriè, Mark Cameron Papers, British School at Athens) that thick layers of plaster are common in Minoan frescoes, esp. of LM II-IIIA, as the preparatory ground onto which the actual painting surface appears; i.e. he did not consider the thickness of the plaster as suggestive of 'many layers' - just one (contra Mirié I979, 52 and n. 3).
} 
Repositories') and room 39 ('Magazine or Gallery of the Jewel Fresco') or - most likely - was blocked in LM II. The important findings of the 1987 investigation - as these have been made available to date by the excavators - will be taken into consideration as we discuss the decorative programme of the Throne Room within the broader context of Minoan and Aegean art.

\section{Of Palm Tree(s) and Wingless Griffins}

The renderings of the fruits and crown of the tree depicted next to the throne provide the most significant elements to assess the 'palm fresco's' place in Cretan art. Generally, the history of palm trees goes back to the Protopalatial period, when the plant made its first appearance in pottery decoration (e.g. a palm on a MM IIB cup and a jug from Phaistos, see Pernier 1935, pls $20 a$ and $3 \mathrm{I}$; also Pelegatti I96I-2). From early on, the upright position of the fruit cluster markedly contrasts with the heavy, drooping fruit clusters of the common, cultivated, date-palm (Phoenix dactylifera), supporting an identification, as also in the case of the Throne Room example, with the Cretan date-palm (Phoenix theophrasti). The antiquity of rendering the fruits in this position is implied by a polychrome jar from the Loomweight Basement, for which Evans already noted a 'local touch' in the rendering of its infructescence (Evans 1928, 493; also Dawkins 1945). ${ }^{25}$ Seal images from Knossos and Kato Zakros (CMS II.7, no. 7I = CMS II.8, no. 298, and CMS II.8, no. 297) (Fig. 28) and the left of the tall palms in the West House miniature frieze from Akrotiri on Thera provide a very similar rendering (Doumas 1999, 64-5, figs 30 and 3I): in these Neopalatial images, the crowns consist of thick and arched leaves in an even arrangement, with a leaf bud growing out from the top and the cluster of fruits placed in the midst of the crown.

The particular rendering with the infructescence or clusters of fruits separating upper (younger) and lower (older) leaves from each other, and with new leaves unfolding at the top of the crown, finds its earliest attestation in the Kamares-style pottery decoration (Walberg 1976, I93, fig. 48:25.i.7). ${ }^{26}$ Closest in shape to the arrangement of palm leaves and fruits in the Throne Room are the palm crowns above red trunks in the LC I (LM IA) wall painting from the 'Porter's Lodge' in Akrotiri, which show two groups of blue palm branches separated from each other at the height of an upward-growing cluster of yellow and red dates (Vlachopoulos 2007, I36 and pls 15:2 and 15:5). Similar (though apparently no clusters of fruits are preserved) are the datepalms in the Minoan or 'Minoanising' taureador scenes from palace $F$ at Tell el-Dab'a, now dated by the excavators to around I500-I450 BC (Bietak, Marinatos and Palyvou 2007, 89, figs Fi7I, Fi72, Fi87, Fi88; Rüden 20II, pl. 42d).

The general shape of the tree itself, with its rather short, straight stem - as opposed to the long, slightly bent stems of the palms in the fresco from the 'Porter's Lodge' and elsewhere - finds parallels in Neopalatial glyptic scenes, such as the palm tree(s) next to 'tree-shrines' on CMS II.6, no. I from Ayia Triada, on CMS VI, no. 362 in Oxford and on the largest gold ring from the tomb of the LH II 'Griffin Warrior' at Pylos (Davis and Stocker 2016, 640-3 with fig. IO). Similar in shape are also the small palms in the LC I miniature frieze from the West House, Akrotiri (Doumas 1999, 64-5, fig. 30). However, the detailed rendering of their stems differs remarkably from the plain stem of the palm in the Throne Room fresco, with its auburn contour line bearing only remote resemblance to the protruding remains of dead branches shaping the outer contour of the Neopalatial palm trees.

After the Neopalatial period, the palm continued to be depicted in Minoan art. Two LM II palace-style jars from Knossos show rows of palms with arched leaves and a leaf bud, though without fruits, separated by rosettes in circles (Niemeier 1985, 76-7, fig. 24, 7, pl. 13, cat. nos III B I and III B 2). Yet the majority of post-Neopalatial palm representations are rendered in a

\footnotetext{
25 The fruits are oval-shaped and clustered in groups; interestingly, some are in groups of three red dots: $K n D r A$ II.F/Ic (ink drawing of the fruits on MM jar now in Oxford, AE I654 = Evans I92 I, fig. I90c).

26 In LM IB, a palm on a rhyton from Pseira appears to show the same elements: old incurved leaves, fruits/ infructescence(?), younger arched leaves, leaf bud on top, in a highly stylised manner: Niemeier 1985, 75-7, fig. 24,4; Evans 1928, 497, fig. 302.
} 


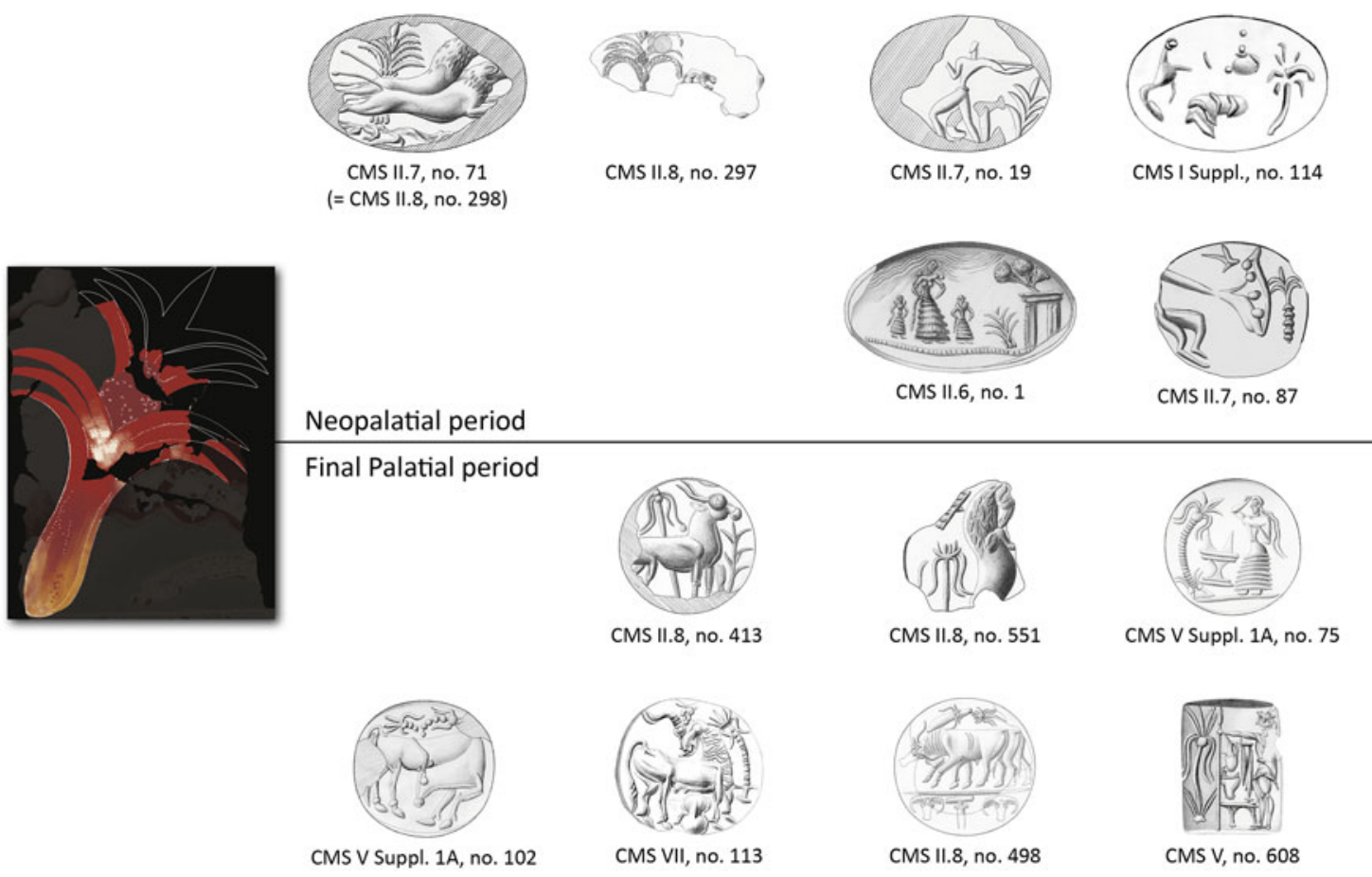

Fig. 28. A selection of images from seals and sealings with palm trees from the Neopalatial and Final Palatial periods. All images of seals and sealings reproduced by courtesy of the Corpus der minoischen und mykenischen Siegel (CMS), University of Heidelberg. Prepared by and courtesy of Ute Günkel-Maschek.

remarkably different way from that attested in the Throne Room 'palm fresco' (Fig. 28). This different rendering made its first appearance in LM IB / LH IIA, namely the simplified and stylised 'drooping and upright leaves' variant as opposed to the 'naturalistic' variant of the Neopalatial period to which the Throne Room 'palm fresco' finds its closest parallels.

A good example of this 'new' rendering is the fruit-bearing palm on the 'Violent Cup' from Vapheio, dating to LH IIA (Davis I974, 475, figs 5, 7; 477, fig. I2, 479, fig. I7). ${ }^{27}$ It shows the lowermost leaves drooping close to the trunk, while the cluster of fruits is placed in the middle of the crown. Above are two curved leaves with a third, straight, leaf bud growing upwards from the middle of the palm's crown. Two young palms growing from the ground are also shown in this composition. They are rendered in a similar fashion: two arched leaves on either side and one straight in the middle above. ${ }^{28}$ After the end of the Neopalatial period, the crown shape of the mature palm with long drooping leaves (tips pointing outwards) and either short upwardgrowing leaves or a larger, single leaf bud (as in LM III examples), became the standard rendering of date-palm representations in Minoan art: from seal images (CMS II.8, no. 498 from Knossos; CMS II.8, no. 55I from Knossos; CMS V Suppl. IA, no. 75 from Knossos; CMS V Suppl. IA, no. I02 from Chania; CMS V Suppl. IB, I37 from Antheia in Messenia) to painted larnakes (Watrous I99I with pls $83 b, 83 f, 84 e, 87 a, 92 d, 92 g, 92 h, 92 i$ ) and pottery.

To sum up: the palm from the Throne Room stands out in preserving the Neopalatial tradition at a time when artistic production favoured, in various media, the simplified and stylised 'drooping and upright leaves' variant for the palm tree (Fig. 28). Given the suggested date for the construction

\footnotetext{
27 Of the palms in the bull-hunting scene on the Katsamba ivory pyxis, only heavily drooping leaves have been depicted, with the middle and upper part of the crowns being cut off by the upper edge of the pyxis; see Hood I978, I22, fig. III(B).

${ }_{28}$ For young palms, see also CMS II.6, no. I60 from Gournia and CMS II.7, no. I9 from Kato Zakros.
} 
of the north wall in LM II, it could be argued that the 'palm tree' in the Throne Room at Knossos forms one of the last attestations of the 'naturalistic' variant in the history of Cretan art.

Yet there is also a certain innovative spirit permeating the creation of the LM II decoration of the Throne Room: on the palm tree, this attempt can be detected in the auburn and red colour of the trunk and of the leaves (Fig. 13). This colour scheme breaks with the established Minoan convention of rendering leaves of palms either in blue colour only, or with blue and yellow, with the bicoloured rendering possibly reflecting the iridescence of the leaves in the sun. For example, this colour convention can be traced in the West House and in the 'Porter's Lodge' in Akrotiri on Thera, at Pylos, as well as in the East Mediterranean (Lang 1969, I29, pls 73 and H, no. II N nws [Pylos]; Doumas I999, 64-7, figs 30-4, I87, fig. I48 [Akrotiri]; Bietak, Marinatos and Palyvou 2007, 56-6I, figs 59A-B, 60 and I50, fig. I38 [Tell el-Dab'a]; Rüden 20II, 74-6, pls 54, 66, 69 [Qatna]). Thus within the Minoan and 'Minoanising' painting traditions of the East Mediterranean, the tree depicted next to the throne at Knossos stands out for its bright-red colour. A similar emphasis on red is also observed in the papyrus flowers in the Throne Room, which are painted red instead of the usual blue as, for example, in the House of the Frescoes at Knossos (Evely 1999, II6) and the miniature frieze in the West House at Akrotiri (Doumas I999, 66).

With regards to innovative elements, the wingless griffins must have formed one of the most impactful features to the eyes of the Late Minoan beholder of the Throne Room composition. Although only the foreleg of one such beast is preserved to the east of the throne in the 'palm fresco', we have argued above that the creature depicted there was most likely a griffin, similar to the griffins shown on the west wall, on either side of the door leading to the 'inner sanctuary' (Fig. 2I). Upon a closer look at the design of the creatures on the west wall of the Throne Room, their innovative nature immediately becomes apparent: neither their winglessness nor their floral decoration has antecedents among the corpus of griffin representations in Minoan and Aegean art. ${ }^{29}$ To this, we may add technical novelties such as the use of cross-hatching in order to create an effect of shading and/or volume (Immerwahr I990, 98 and I6I; Evans's attempt for 'chiaroscuro': 1935, 913, fig. 886).30

At the same time, the style of the creatures' floral ornamentation itself can be placed within the representational repertory of the LM II painter. Although recalling decorative schemes of the MM Kamares style, the idea of placing rosettes in the centres of volutes became particularly popular only in the LM IB period, e.g. in the relief friezes of running spirals decorating a room in the newly built palace at Kato Zakros (Platon I971, I72-3; Immerwahr 1990, I84 cat. no. Za No. I; for the LM IB date of the palace, see Platon 2002). The LM II fresco programme at Knossos, too, included a number of friezes of running spirals with rosettes in the centres, especially in the East Wing of the palace, where it is contemporary to the Throne Room fresco (Evans 1930, 335, fig. 229; 383, fig. 254; col. pl. 23; for further fragments, see Cameron 1976, pl. I40). In pottery decoration, the centre position of rosettes within spirals, but also volutes of plants or marine creatures, takes

\footnotetext{
29 Zouzoula 2007, 97-9, I50-60 and 267-76 (with earlier references); also Morgan I988, 49-54; Morgan 2010; Shank 2003, 94-I20; forthcoming. Wingless griffins and sphinxes appear early on in Aegean art. Wingless sphinxes probably appear in Pre-palatial times (e.g. the theriomorphic CMS V Suppl. IA no. 22I) and in a few instances in MM II-III (e.g. CMS VI, I28; and as clay relief decoration on pottery: Mallia). Wingless sphinxes continue to appear in LM I (Chania sealing, part of multiple sealings: CMS V Suppl. IA I34). Both winged and wingless sphinxes, however, do not appear in EM III - LM I in connection with human figures and do not seem to engage in significant action, as opposed to griffins. They become more active from LM II onwards (e.g. the winged sphinxes on either side of a pillar on the signet ring from chamber tomb 55 at Mycenae or the Tanagra larnax, placed side by side with human figures and the 'pillar cult'). Wingless griffins are equally attested as early as the MC (MH II) period, as suggested by the Melian bowl found in the MH II warrior grave at Aegina (KilianDirlmeier 1997: 6I, fig. 3I,I5) but they are rare. There are also two possible LM I representations (CMS III, nos 399-400) which are contemporary and similar in style and arrangement to the wingless sphinxes mentioned above (CMS V Suppl. IA no. 134). Another wingless example appears on a LM IIIAI handleless pyxis from Mochlos tomb 7 (Smith 2010, I02-3 IIB.79I, fig. 68, pl. 26).

30 Blakolmer (201 I , 67-8) thinks that the cross-hatching was made in order to create an imitation of stucco relief, which he believes to have formed an antecedent of the Throne Room fresco.
} 
its most detailed form - e.g. with rosettes being rendered more carefully - in the LM II period. ${ }^{{ }^{\mathrm{I}}}$ These comparisons suggest that an attention to these details was generally mostly at home in LM IB late / LM II painting. As in the Throne Room decoration where papyrus-reed hybrids grow in the landscape surrounding the griffins, in palace-style pottery too this decorative scheme appears occasionally in combination with lotus and/or papyrus flowers (e.g. Evans 1935, 326, fig. 268; also the LM II papyrus-lotus on an amphora from the Royal Villa: Evans 1935, 331, fig. 273; Niemeier 1985, 2356, no. II A 3; Hatzaki 2007, 198, fig. 6.1).

Also of interest are the lotus and 'waz' hybridised flowers dangling below the rosette-centred volute on the creature's shoulder, as attested in the best-preserved griffin (south part, west wall) (noted and drawn by Evans: $A E / N B$ 1900, I6 April, 46; this motif is described as a 'papyrus' by Niemeier I985, 43-5I, fig. I4(I),II) (Fig. 29a). The pale blue-grey sepals with the rose-red 'waz' filling motifs are heavily defined in black, with dark-red blobs for the inflorescence. The two plant forms united in the composite flower derive from Egyptian art, where they played an important role in religious concepts of creation, life and eternity (Bunson 2002, 218, s.v. lotus). The Minoan hybrid form of this motif had been conventionalised in art by LM I: close in style and shape to the motif which appears on the Throne Room griffins and the hybrid plants are, for example, the lotus-papyrus hybrids in the fresco assigned to the south wall of the pavilion in the Caravanserai at Knossos (Shaw 2005, I00 nos 28-30; I07 [LM IA date of execution]; cf. Cameron 1976, vol. 3, 99 and pls I00A and I00B(a); Evans 1928, II6), and those from the fresco decoration of room I4 in the villa at Ayia Triada (Cameron 1976, vol. 3, 99 and pl. 82C; Militello 1998, I07-I5, pls 5-6 [dated to late in LM IA / early in LM IB, with the floral decoration also finding good parallels in the LM I pottery of the time])..$^{22}$

Decisive for the LM II date of the Throne Room fresco are also the curved elements framing the papyrus fillings of the hybrids on the shoulder of the griffins. They are echoed by the kidney-shaped elements framing the outer edge of the lotus flower in palace-style pottery of the early type (on the 'nierenförmige Gebilde' see Niemeier 1985, 46). Like the rosettes placed in the centres of the volutes (also on the griffins' bodies), the lotus-papyrus composites show a clear development from earlier Minoan painting traditions and find good parallels in contemporary LM II pottery decoration (Fig. 29b). Despite the striking similarities, the position of this motif on the creature's body is another innovation in the long history of griffins in Aegean art.

As to the possible source(s) of inspiration for the overall scheme and compositional details of the main zone of the Throne Room fresco, scholars have consistently referred to contemporary Egyptian art. Evans recognised the exceptional nature of the representation of the griffins, which he interpreted as 'possibly due to some assimilation with the Egyptian Sphinx' (Evans I899I900, 40; I935, 913-I4).33 Cameron compared the floral ornamentation of the creatures to the 'garlanding of sacrificial bulls in contemporary Egyptian frescoes' (Cameron 1976, 496). Marinatos $(2009,26)$ drew attention to the shoulder position of the rosette on the body of the Throne Room griffins recalling the ornament placed on the shoulders of lions in Egyptian representations (this decorative scheme finds further parallels in some glyptic representations of lions from the mainland, e.g. CMS I, no. 60, from Mycenae; possibly also CMS I, no. 374, from Pylos). However, against the background of LM IB developments in art, and given the earlier development of placing dots in the centre of griffins' spirals (Doumas 1999, 64-5, figs 30,

\footnotetext{
3I The centre position of rosettes within spirals appears in the course of LM IB and continues to LM IIIAI: see Niemeier 1985, passim: e.g. rosettes in ivy, 69, fig. 22(2); rosettes in the volute arms of argonauts, 24 fig. 5(2); and 86-7. Cf. Popham I984, pl. I68 (LM II) with pl. I7I (LM IIIAI).

32 Cf. Shaw 2005, I08-9 and also the 'papyrus' representation on a table of offerings from Phase D at Phylakopi (LB I-II): Renfrew et al. 2007, iv and 389-90, fig. 9.10 [SF I22 I, entry by L. Morgan].

33 It is tempting to see an innovation in contemporary Egyptian architecture as a possible source of inspiration for the Knossian wingless griffins: the first ever built avenue of hundreds of sphinxes, arranged in antithetical pairs behind one another, leading from the Nile River valley up to the terraces of Hatshepsut's mortuary temple at Deir el-Bahri (Szafrański 20I4, I32-4 with fig. 7.10). In the funerary chapel of Hatshepsut's chief architect Senenmut, who was in charge of the construction of her mortuary temple, we find an early representation of people from Keftiu as gift bearers (Dorman I99I; Panagiotopoulos 200I). This idea is currently being developed further by Günkel-Maschek.
} 


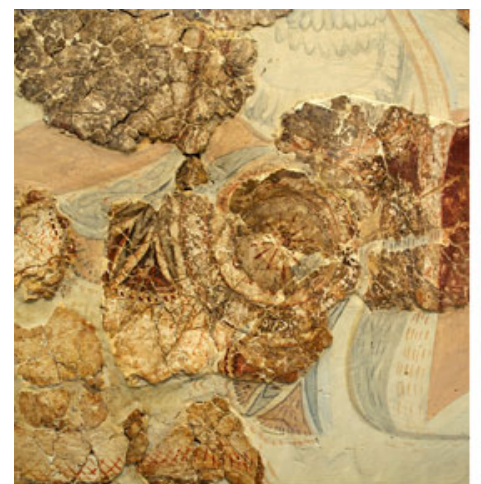

(a)

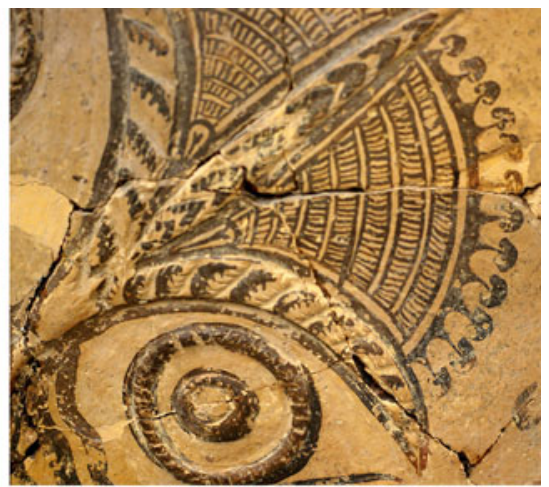

(b)

Fig. 29. (a) Detail of the lotus-papyrus motif on the shoulder of the best-preserved griffin from the Throne Room at Knossos; (b) LM II storage jar in the palace-style decoration from the Royal Villa at Knossos. By the authors. Courtesy of ҮП.ПО.А. Т.А.П. - Archaeological Museum of Herakleion, Hellenic Ministry of Culture and Sports - Archaeological Receipts Fund.

32, West House miniature frieze; I59, fig. I22 and I65, fig. I28, Xeste 3), the decision to place a rosette in the centre of the volute on the Throne Room griffins could still have been a result of the representational schemes, which were en vogue in Minoan painting at that time. On the other hand, the combined evidence of the innovative features just mentioned and their undeniable comparanda in Egyptian art clearly give reasons in favour of the argument that the design of the wingless creatures in the Throne Room might have been inspired by, or born out of, the contacts between Knossos and Egypt at that time.

In summary: the representation of both the palms and the griffins marks a break in the tradition of rendering these two elements in Minoan and 'Minoanising' art in the East Mediterranean. More importantly, it marks a break in the established design of images of powerful landscapes and figures, with seated or enthroned figures of authority among them, in Minoan art itself. Like the redcoloured fruit-bearing palm, the wingless and florally embellished griffins appear to be the result of an innovative artistic spirit which flourished at the onset of LM II, aspiring to produce a new - yet still recognisable - image of power for the actions taking place in the Throne Room, and in particular for the occupant of the stone seat, a point to which we return below.

\section{The dado zone: incurved 'altar-base', lattice pattern and 'veined stone'}

Contrasting with the landscape scenes in the main zone, the decoration in the dado zone of the Throne Room Fresco with 'altar-bases' and an imitation of stone veneering was more reflective of the 'indoor' surroundings of the stone seat, its occupant and related actions. The history of 'altar-bases' goes back to MM IIB, when it first appeared as a terracotta model (interpreted by Evans as representing a Minoan shrine: Evans I92 I, 220-2, fig. I66H; 1928, 607, fig. 380). In the Neopalatial period, incurved altars were amply used (Shaw I986, II4-I5), e.g. as actual objects placed in entrances and areas linked with ritual, and as images or decorative elements serving a similar, ritual, function to the actual objects. The relief-carved steatite rhyton from Zakros reproduces the placing of an incurved 'altar-base' in one such sacred enclosure (Hood I978, I46, fig. I40). However, the majority of images in glyptic art, in wall painting and in ivory carving depict incurved 'altar-bases' as supportive elements in platforms and other built structures: e.g. the relief-carved lid of an ivory pyxis found at Mochlos (Soles 20I6, 249-5I, pls LXXXI-LXXXII) and, similarly, the painting on the north wall of polythyron hall 3 on the upper floor of building Xeste 3, Akrotiri (Doumas 1999, I58-9, fig. I22; also Palyvou 2006). MM IIIB/LM IA fresco fragments from the Ivory Deposit at Knossos also show a structure supported by 'altar-bases' alternating with double axes, which possibly served as background to a 


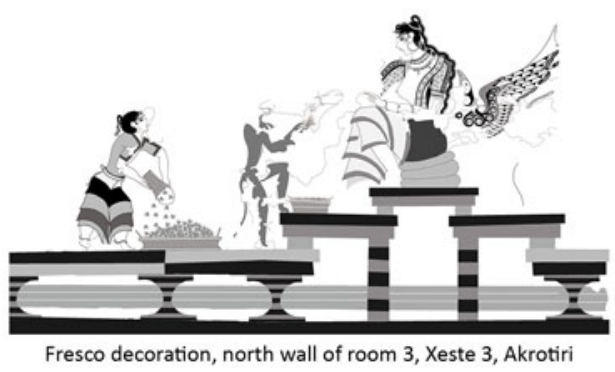

Fresco decoration, north wall of room 3, Xeste 3, Akrotiri

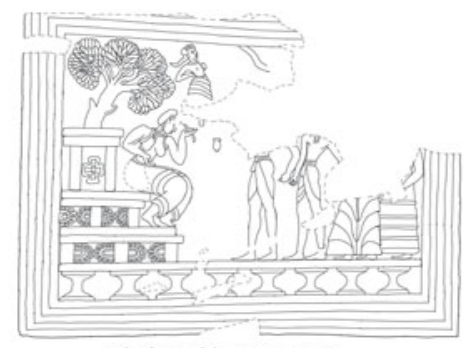

Lid of Mochlos ivory pyxis

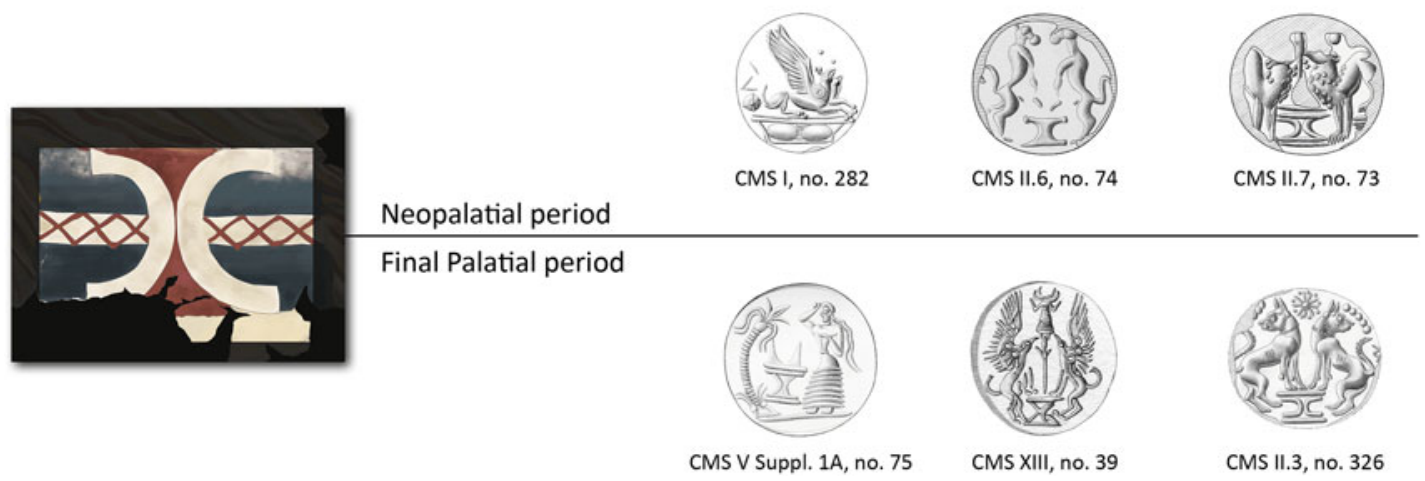

Fig. 30. A selection of images with altars from the Neopalatial and Final Palatial periods. Upper left: Akrotiri, Xeste 3, north wall of room 3a (first floor); drawing by Günkel-Maschek after Doumas I999, I58-9, fig. I22. Upper right: Mochlos ivory pyxis; drawing by Ute GünkelMaschek after Soles 20I6, 249-5I, pls LXXXI-LXXXII. All images of seals and sealings reproduced courtesy of the Corpus der minoischen und mykenischen Siegel (CMS), University of Heidelberg. Prepared by and courtesy of Ute Günkel-Maschek.

bull-leaping scene (Hood 2005, 70-I, cat. no. 20). On a lentoid seal from Routsi tholos tomb 2 in Messenia, two winged griffins are shown crouching on top of a structure supported by what could be an 'altar-base' (CMS I, no. 282) (Fig. 30). Altogether, these images reveal the connection between 'altar-bases', seated or enthroned (female) figures, and (winged) griffins - a connection which appears to have been reproduced in the spatial and visual arrangement of the stone seat and fresco decoration of the LM II Throne Room (Fig. 27).

Unlike many Neopalatial depictions of incurved 'altar-bases', the one in the 'palm fresco' is lacking the multiple horizontal lines traversing the body of the base. In fact, the way in which the 'altar-base' was depicted, with two incurved bands in low relief ('impasto') enclosing a central filling area, has no known parallels in Minoan painting. It was more at home in reliefcarved glyptic images from the Neopalatial period (e.g. CMS II.7, no. 73, from Zakros) and from the Final Palatial period (e.g. CMS V Suppl. IA, no. 75, from Knossos) (Fig. 30). The representation of the 'altar-base' in the Throne Room fresco thus clearly preserves the incurved shape of its Neopalatial predecessors. Yet it presents this symbol in a new style without following the common design described above. 34

The 'altar-base' is set against a blue-grey background, traversed horizontally by a white band filled with a red lattice pattern. This position of an 'altar-base' in front of a horizontal band most closely resembles the arrangement of incurved 'altar-bases' in front of a triple horizontal red band in the lowermost section of the podium which serves as the seat of the Goddess in the LC I (LM IA) wall painting from Xeste 3 at Akrotiri on Thera (Doumas 1999, I58-9, fig. I22). A similar composition was possibly shown on inlays belonging to the MM III 'Town Mosaic' from

34 The 'cut-out'-style altar is, however, attested in later paintings: Lang I969, I05, pls 46, I32, no. 3 C 20 (Pylos). 
Knossos, with three horizontal bands continuing on either side of an incurved object (Evans I92 I, 304, fig. 223; 306, fig. $226 \mathrm{~N}$ ). No direct parallels exist, however, for the co-occurrence of bands with a lattice pattern with incurved 'altar-bases'. The ornament itself does occasionally appear in wall painting, most notably the paintings in the niches next to the Central Court of the palace at Phaistos (Pernier and Banti I951, 60-3, figs 25-6; 444, fig. 277; Cameron 1976, vol. 3, I22, pl. I42; Immerwahr I990, I83, cat. no. Phs No. 5), though fragments are also known from the palace at Knossos itself (Cameron 1976, pl. I43, regarding the fragments from the Loomweight Basement, the area east of the Hall of the Double Axes, the Area of the North Threshing Floor and from the Hogarth's Houses).

A cushion seal said to be from Priene, now at the Ashmolean Museum in Oxford (CMS VI, no. I8I), shows a hollow square construction (trough or cistern?) decorated with a lattice pattern (a cross and outline of lozenges). A bull stands with its forelegs and muzzle over the rim of the construction while a man leaps onto its neck - perhaps part of a bull-leaping scene. This representation has been related, though not undisputedly, to the palace at Phaistos and the painted niches close to a stepped structure in the north-west corner of the Central Court (Younger I995, 5I2-I3 with further references). A lattice pattern (or crosses) also appears on the 'door opening' of the 'tree-shrine' on the so-called Ring of Minos, the tree being touched and/or harvested by a male figure (Dimopoulou and Rethemiotakis 2004, I7, fig. I0); and a whole net of lattice pattern covers the front of the 'tree-shrine' on the large gold ring from Pylos, which had been mentioned earlier with regard to the palm trees flanking this same 'tree-shrine' (Davis and Stocker 20I6, 640-3 with fig. I0). These representations indicate a connection between the lattice pattern as a motif of palatial/elite architecture and at least two prominent elite ritual contexts of the Neopalatial period: bull-leaping and what we may describe as ritual actions in front of 'tree-shrines'. This association appears to strengthen further the chronological closeness of the 'palm fresco' from the Throne Room at Knossos and the artistic traditions of the Neopalatial period.

Enclosing the field with the incurved 'altar-base' and lattice band, and running along the west, north, and east walls of the Throne Room, the dado zone is filled with multicoloured wavy lines, creating an image of 'veined stone' decoration. The history of imitating stone veneering in architectural decoration goes back to the Middle Minoan period (Evans I92 I, 355-6, fig. 255; Evans 1935, 894-6, fig. 874; Hood 2005, 80, cat. no. 34, fig. 2.31). Interestingly, the 'veined stone' dado in the Throne Room fresco is different from the contemporary dado in the West Porch at Knossos, which consists of alternately square and oblong panels of marble imitation (Evans I935, 893-5 with fig. 873 and n. I; Hood 2005, 66-7, no. I4, fig. 2.I6). In the variation of patterns and colours, this latter example is closer in style to the panels of the MM III 'Marbled Dado' from Knossos, but also to those in the dado zones of the wall paintings from rooms 4 and 5 in the LC I West House at Akrotiri (Doumas I999, 50-I, figs I4-I7; 86-9I, figs 49-56; for the 'Marbled Dado' see Cameron 1976, vol. 3, I25 and Fotou 2004, 96-7, fig. 6.7, with references). In the Throne Room, however, no attempt was made to create a 'realistic' impression of panels of 'veined stone', though the design certainly echoes the Neopalatial tradition of imitating stone dadoes. 35

The direction of slanting on the north wall forms an interesting pattern: on the west side of the throne, the slanting is from right to left $(/ / /)$, whereas the left-facing griffin to the east of the throne is set on top of wavy lines slanted from left to right (III). However, on the west wall, the best-preserved griffin on the south part of the west wall is right-facing and set on top of wavy lines that also appear to slant from left to right (III), at least in the small 'veined stone' fragment preserved. That being said, the mirror-inverted slanting of the veins - at least on either side of the throne (I/I III) presents us with a new usage of this long-known decorative design in order to 'focalise' further the stone seat and its occupant.

\footnotetext{
35 Dado remains were found under the floors of rooms 44, 44a and 46, but in Period II (Neopalatial) when room 44a extended into room 46 of the service section. We would like to thank Vasso Fotou for clarifying this point to us. For the remains of gypsum dadoes in the Service Section, see Catling 1987-8, 68. Similar remains were brought to light, e.g. in the West Porch of the palace: see Evans I928, 668 with fig. 425.
} 


\section{BETWEEN 'TRADITION' AND 'INNOVATION': INTERPRETING THE THRONE ROOM'S DECORATIVE PROGRAMME}

Following the conservation of the 'palm fresco', we can now ascertain that the occupant of the throne was closely related to a fruit-bearing, and thus female, palm tree. The iconographic attention given to the area of the throne is therefore different from that which frames the door leading to the 'inner sanctuary', undoubtedly flanked by evenly spaced papyrus-reed hybrids on undulating and alternating red and white wavy bands against which two crested wingless griffins were shown crouching (see Shaw 1993, 676-8) (Figs 21, 27). The date-palm, which is set at an angle as if it springs from the stone seat, ${ }^{36}$ may add further to the debate regarding the significance and function of the throne and its occupant, as well as of the room's iconography in the final period of the palace that ended, in our view, in LM IIIA2.

Evans believed that the date-palm had been introduced to Crete from Egypt early in Minoan times and had become a familiar feature of the Cretan landscape by the end of the Protopalatial period, when it made its first artistic appearance (Evans I930, I77, n. I). Generally, the symbolism of the fruit-bearing date-palm could have developed around the knowledge of its dioecious nature and artificial fertilisation methods (as suggested by Dawkins 1945), 37 but also in assimilation to Egyptian and Near Eastern ideas, where the date-palm was a symbol of prosperity and fertility, the 'tree of life' (Marinatos I984a, I2I-2; also Antognelli 2006; Antognelli Michel 2012; Karetsou and Girella 2015, 76-80 and 99-104). Yet to Bronze Age Cretans the local date-palm, with its inedible fruits (Murray and Warren 1976, 46-7), may not have had the same symbolic significance as in contemporary East Mediterranean societies.

As Evans first observed, when fruit-bearing palms are represented in the Aegean they show immature dates springing up from the central stem of the palm, as in the case of the Throne Room fresco, but never the ripened fruit ${ }^{38}$ (Evans 1928, 493; Murray and Warren 1976, 46; Antognelli Michel 2012, 50, n. 84; on dates and date-palms in the Bronze Age Aegean, see also Niemeier 1985, 73, n. 424; Morgan 1988, 24-9; Sarpaki 2000, 663-4; Rüden 201 I, 76). In fact, the Cretan images of fruit-bearing palms are in marked contrast to representations of similar local date-palms in Egypt and the Near East, where they are (almost) always represented with two big date clusters hanging from the foliage of the tree. 39

The infructescence of the palm in the Throne Room decoration is noticeable, but this was probably different in significance from the Mari 'investiture painting', which is often mentioned in scholarship in interpreting the Throne Room composition (e.g. Marinatos 1989b). At Mari (Bradshaw and Head 2012) the fruits are ripe, men are picking them up and the interest is in creation, divine power and the 'tree of life'. Iconographic elements may indeed have been 'borrowed' by Cretan artists from across the East Mediterranean - but they then appear to have introduced them to the local context, intelligible to a local audience. This transference of

\footnotetext{
${ }^{36}$ In Neopalatial action scenes with human figures present, e.g. on rings or wall paintings, the palm is often set at an angle (CMS II.6, no. I and CMS II.7, no. I9 and the 'Porter's Lodge' fresco from Akrotiri), suggesting that its position is not accidental.

37 Marinatos (I984a; 2007) argues that the palm in Minoan art symbolises fertility and procreation. She also attributes solar connotations to palms and griffins in Aegean art based on Near Eastern parallels (Marinatos 2007; 2010, esp. 58-65). For the symbolism of the palm tree in ancient art, see Evans 1928, 493-9, Danthine I937 and Marinatos 1984a; for the fruit-bearing palm as an 'agricultural abundance' symbol in Assyria: Winter 2003.

$3^{8}$ Very little has been identified archaeobotanically in terms of date stones: two instances are mentioned from Crete, from a 'LM IIIC space' and from a 'Hellenistic well', both identified in the 'Little Palace North excavations' at Knossos (200I-2; under study by Alexandra Livarda; pers. comm. from Alexandra Livarda, I3 January 2015).

39 For an overview of I8th-dynasty Egyptian date-palm representations, see Gothein and Wright I928, I-25, esp. II, fig. IO; I3, fig. I4; 20, fig. 20; 2I, fig. 2I; 22, fig. 23. For further examples in Theban funerary painting, see Bruyère 1959, pls XIX, XXVII; Parkinson 2008, I33, fig. I42 and I37, fig. I46; Bruyère and Kuentz 20I5, pls XXXII, XXXIV. For Near Eastern representations of date-palms in wall painting, e.g. from the palace at Mari, see Parrot 1958, pls VIII, IX, XII, col. pl. A.
} 
iconographic elements may have included some elements of belief and ideology, but not a wholesale adoption of a belief system from one land to another.

It is remarkable that, in Neopalatial imagery, the palm did not receive attention in the form broadly described as a Minoan 'tree cult', which included rituals such as 'tree-hugging' (Marinatos I989a; Day 20I2). Palm trees were conceptualised in a different way. They were part of idealised 'Aegean landscapes': ${ }^{\circ}$ from the West House at Akrotiri on Thera, ${ }^{4 \mathrm{I}}$ where wildcats chase waterfowl and griffins pursue deer among papyri and palm trees (cf. Karo 1930, pls 26 and 33 from Mycenae), to glyptic scenes depicting male hunters (CMS II.7, no. I9; Fig. 28) and the 'violent' Vapheio cup and the ivory pyxis from Katsamba, where palms grow in the rocky environment of bull-hunting and bull-leaping. In these cases, the palm appears in scenes exhibiting 'aggressiveness' and/or hunting prowess of animals and men. Other representational cycles, however, suggest possible association with further ritualised contexts, such as the depiction of a male figure approaching a fruit-bearing triple palm in the fresco from the 'Porter's Lodge' at Akrotiri (Vlachopoulos 2007, I36 and pls 15.2, 15.5) or of a seated female figure with a flounced skirt on a Cretan-style signet ring in Athens (CMS I Suppl., no. II4, context unknown, but said to be from Crete; Fig. 28). On the Athens ring, in particular, the female figure is set between a palm (placed at the back of the figure) and an animal (lion?) standing on its hind legs (in front of the figure). On one of the two gold signet rings from the Antheia tholos tomb in Messenia (CMS V Suppl. IB, no. 136), we find a lion in a similar posture to the Athens ring associated with a palm; but instead of a human figure, we have here a cow nurturing its young. The palm appears in the background, while another tree is set at the back of the cow. All in all, then, although both palm and olive trees most likely did occur in the rocky environments of Bronze Age Crete, the appearance of the palm in Neopalatial scenes (e.g. of bull-leaping, of human and animal hunters, and of seated female figures), strongly suggests the tree's perception as a marker of a sphere encompassing the real and the supernatural world. ${ }^{42}$

Most relevant to our discussion here is the depiction of palms next to 'tree-shrines'. On the largest gold ring from the tomb of the LH II 'Griffin Warrior' at Pylos, a 'tree-shrine' is placed in the centre of the composition. Palm trees set at a similar angle to the palm from the throne in the Throne Room at Knossos flank the 'tree-shrine' (Davis and Stocker 2016, 640-3 with fig. I0). Two groups of women, at either end of the composition, complete the scene (part of the same scene, with a 'tree-shrine' and one palm only as the ritual focus of one adult and two small-sized female figures, was already known from CMS II.6, no. I from Ayia Triada). This new discovery appears to reinforce further the suggestion that palms could be positioned next to focal objects, highlighting important structures and the associated ritual action.

The 'tree-shrine' cycle in Neopalatial imagery is important for our discussion here as, in all likelihood, it was associated with what was going on in lustral basins (for a recent survey of lustral basins and the nature of the rituals performed there: Klahr 20II; Puglisi 20I2). The Xeste 3 lustral basin fresco at Akrotiri, which shows a 'tree-shrine' as the focus of ritual activities performed there (associated with women) and probably also in the neighbouring room $3 \mathrm{~b}$ (north; where the corridor decorated with male figures led to), gives us an important link between this very particular type of architectural space and a 'tree-shrine' depicted in focal position (Vlachopoulos 2008; 2016; for the link between 'tree-shrine rituals' in art and lustral basins, see Günkel-Maschek 20I2, I27-30). In Xeste 3, the actual space of the lustral basin may also be linked with the image of the 'Seated Goddess' on the floor right above (part of the

40 A MM IIIA jar from Kommos suggests that coherent river scenes were depicted as early as this period. Flowers, palms, and watercourses were already combined into coherent landscapes in ways that were typically Minoan (Betancourt forthcoming).

4I For griffins set in an undulating landscape with palms and rosettes see the MC cylindrical pithos from Akrotiri: Papagiannopoulou 2008, 436-8, figs. 40.5-40.8. For further vessels, see Rüden 20II, 75, pl. 42c.

$4^{2}$ Cf. Vlachopoulos (2007, I32) who, following Marinatos (1987, I38-40; I988, I38), interprets the Akrotiri fruitbearing palms from the 'Porter's Lodge' as representing a 'sacred space', one that alludes to 'the identification of the man as a high-status adorant performing some kind of ritual'. A seated Potnia and, perhaps, a griffin with open wings beside her appear to have been part of the aforementioned composition (Vlachopoulos 2007, I35). 
crocus-gathering and crocus-presentation imagery: Vlachopoulos 2008; 2015). The Mochlos ivory pyxis, where an enthroned figure is shown seated next to a 'tree-shrine', provides us with yet another direct correlation between 'seated figures' and 'tree-shrines' (Soles 2016). It is thus likely, in our view, that 'tree-shrines' could be understood also without the seated figures as a reference to them, and vice versa. In this regard, CMS I Suppl., no. II4 is also very interesting, since it shows that palm trees could appear next to an enthroned figure, and in a similar way they could appear next to 'tree-shrines' (Fig. 28).

Following this line of argument, these 'tree-shrine' representations, and associated visual cycles that also include rituals such as 'tree-touching' and 'baetyl-hugging', have to do with (a) ritual activities in lustral basins and (b) enthroned figures, for which - via some aetiological narrative that we will probably never understand completely - 'tree-shrines' are sometimes substituted. All in all, these interconnections could suggest that in the Neopalatial version of the 'Throne Room' at Knossos, the lustral basin coexisted with a throne of some kind, or at least a seated figure. Furthermore, palm trees positioned next to focal objects in ritual scenes may have been more commonplace than previously thought.

Judging by the Throne Room composition, by LM II palms were combined with another very prominent Neopalatial topos - the guardianship of the griffin. Very relevant to this discussion is the study of Maria Shaw (1993) on the 'Aegean garden', in which she compared the fresco on the north wall of the Throne Room to the 'Mistress of the Animals' fresco from Xeste 3 at Akrotiri. The architectural and iconographic similarities (throne, benches, incurved altars, all set against a painted floral landscape) with the griffin as 'guardian of the seat' (Shaw 1993, 677) could add weight to the idea that the artistic, and perhaps ideological, foundations of the scene decorating the Throne Room at Knossos were indeed Neopalatial in origin (an idea already alluded to by Immerwahr 1990, 96; for the association of enthroned figures with the natural landscape and even rulership in Neopalatial times, see Tully and Crooks forthcoming).

It was only in the Final Palatial period that the palm became more prominent as a symbolic addressee of religious-ritual gesture and of bull sacrifice, and it could well be that the association of the palm with the stone seat and its occupant in the Throne Room stimulated the formation of such scenes. The palm continued to be part of lion scenes (CMS II.8, no. 55I, from Knossos) and of bull scenes. The latter, however, exhibit a stronger emphasis on animal sacrifice, with images showing bull and palm (e.g. CMS II.8, no. 4II3 from Knossos; CMS V Suppl. IA, no. I02 from Chania), the two accompanied by a figure-of-eight shield and a skull/ frontal head (CMS VII, no. II3 from Ialysos) and, especially, the palm tree in scenes of bull sacrifice (e.g. CMS II.8, no. 498 from Knossos; CMS I, no. 5I5 from Mycenae) (Fig. 28). Moreover, the palm is addressed in scenes of ritual gesture and offering (e.g. CMS V Suppl. IA, no. 75 from Knossos; CMS V, no. 608 from Naxos).

A particular meaning or association had therefore been ascribed in the Final Palatial period to the palm tree within the context of religious cult activity and - possibly - also a more specific association of the palm with a particular recipient of veneration. According to Marinatos, for example, the palms in these and other Final Palatial scenes should be understood as meaningful signs, as standards of some kind, rather than as landscape elements of a decorative nature (Marinatos I984a, II6, I20-2; in a later publication, Marinatos [2010, 63] even recognises them as 'human-made cult standard[s]'). In a similar vein, Morgan saw the palm tree as an allusion 'to the desired presence of the deity for whom the sacrifice is intended' (Morgan 1995, I42; also Hiller 20II). A comparable association could have been evoked by the palm tree placed above an incurved altar framed by sphinxes on a clay pinax, possibly of LM IIIA-B date, from room V in the Minoan villa at Kannia near Gortyn (Levi 1959, 249, fig. I9; Rutkowski 198I, fig. I2,9; Marinatos I984a, I20, fig. I3; Niemeier 1986, 86-7, fig. I6; the context of discovery of the Kannia pinax is described by Antognelli Michel [2012, 49] as 'a real sacellum: found in situ on the south bank with many other cult objects'). It is within this artistic context that the makers of Minoan larnakes may have taken the idea of a sacred landscape vegetated with palms, papyruses and other plants into the funerary realm, where this highly symbolic landscape became the eternal environment of the deceased in LM IIIA2-B (Antognelli Michel 2012). 
At the onset of LM II, then, the ideas conveyed by the fruit-bearing palm in the Throne Room fresco may well have drawn inspiration from the preceding, LM IB, context where the palm not only marked an encounter zone between the human and the divine - between hunters and hunted, of the existing and of the supernatural world (Shank 2003, I26) - but also served as a framing device to focalise an object of ritual action. The prominent position of the palm, next to the throne, strengthens the impression that the choice of this particular rendering was made in order to situate the occupant within an idealised realm that by then had already been evoked by palm trees for centuries. Its bright-red colour, unique within the Minoan painting traditions, suggests a conscious effort to break with convention and to create an innovative image for the area of the stone seat and its occupant. 43

It is worth adding at this point some thoughts on the total composition framing the throne and its occupant. In the main zone of the wall, where no traces of the pictorial decoration have been preserved to the west of the stone seat, it has to remain entirely conjectural whether a second palm tree and indeed a second griffin ever existed. That being said, in the light of the new evidence from Pylos, we think that a symmetric arrangement with a second tree mirroring the palm on the east side remains the most plausible solution (Davis and Stocker 2016, 640-3 with fig. IO). Symmetry in the overall composition is further hinted by the mirrored slanting of the veins in the dado zone. In our view, the veining in combination with the 'altar' in front of the lattice band, which filled the space between the throne and the stone bench east of it, strongly suggest the existence of another 'altar' in combination with veining and stone bench to the west of the throne, thus completing a symmetric arrangement of the dado decoration.

However, it remains a matter of speculation whether, on top of this dado, the beast indicated by the front paw to the east of the throne had a counterpart on the opposite flank of the stone seat, completing a symmetric arrangement of the total composition. Taking into consideration the indices for symmetry in the fresco on the north wall just outlined, and based on the fact that the door leading to the 'inner sanctuary' was indeed flanked by two griffins, we think that a symmetric arrangement framing the throne and its occupant still appears the most plausible scenario (Figs I6, 27).

As discussed above, enthroned figures, palms, 'altars' and griffins have their antecedents in LM I ritual scenes (for enthroned female figures in Minoan art, see also Günkel-Maschek 20I6). If the dominant pictorial elements were still 'read' and 'understood' in LM II as in Neopalatial times, as we assume here, then we would argue that in the Final Palatial context the palm not only created, together with the papyri, an allusion to the idealised landscape that shaped the environment of the Throne Room as a whole - in the Neopalatial tradition of 'artificial outdoor spaces' 44 - but also acted as a 'focalising device' (Bennet 2007) for the throne and its occupant (more on that below). Within this framework, the griffin marked the supernatural/divine status of the occupant of the throne, while the incurved 'altar-base' evoked the sacred sphere in which throne and occupant were located and marked off his/her particular space from that of other participants in the room. Unlike many of the other Neopalatial picture cycles, which had been particularly connected to the depiction of enthroned figures (Rehak 1997), the combination of griffin, palm tree and/or 'altar-base' persisted in the art of the Final Palatial period and beyond. 45

\footnotetext{
43 It is tempting to relate this red palm to po-ni-ki-jo, of unknown etymology in Greek, that Murray and Warren (1976) interpret as a Minoan word that by LM II-IIIA may have stood for 'safflower' (red safflower dye) and was used in general as an adjective for red (also Foster 1977). In the context of the very bright-red palm from the Throne Room at Knossos, this connection may indeed find further support. Peters (2008, I94, fig. 9.2) has also highlighted the prominence of red in Neopalatial frescoes and its dominance in LM II; also Blakolmer 2013.

44 In art, the action is placed in outdoor settings - but evidence like the Xeste 3 lustral basin with a painted 'treeshrine' as the 'focus of ritual' suggests that the ritual action itself actually took place indoors (Günkel-Maschek 20I2, I27-3I). These 'indoor/outdoor spaces' are probably where those rituals, referred to in Neopalatial imagery, were performed.

45 The symmetric arrangement, rare as it was among Neopalatial ritual scenes, gained particular popularity in glyptic art in the so-called heraldic schemes from LM I, and especially LM II onwards. Blakolmer (20II, 73) acknowledges carefully that the emblematic compositions only became more common from LM II onwards.
} 


\section{THE FUNCTION OF THE THRONE ROOM IN THE FINAL PALATIAL PERIOD}

There are many unknowns regarding the use(s) of the Throne Room at Knossos. The very label of this room forces us to think of this space as the political centre par excellence of the whole complex. Yet that is only a modern label that contributes further to the blurred picture we have both with regards to the dating of the various architectural phases and of the functions that the room (and the complex as a whole) might have hosted. The throne itself and its occupant were focal points for the small group of people who may have gathered there (maximum 20-25), in the anteroom (another I5-20 people), and perhaps the larger crowds gathered outside in the Central Court. The LM II remodelling of the Throne Room, associated with the 'palm fresco', only gives a terminus post quem (Cameron 1976, vol. 3, III-I2; Mirié I979, 54-6; Niemeier I986, 93-5; Shank 2003, I9-33), while the finds from the Throne Room itself, including the numerous alabastra, all appear to be LM II-IIIA in date (Warren I969, I95-20I; Arbin I984).

Regarding the function, or functions, of the LM II-IIIA Throne Room, a lot still depends on those stone alabastra and on the overturned pithos (Fig. 3ra). For Evans, this material represented clear evidence for a final event that took place in the room moments before its final destruction by an earthquake in LM IIIA (Evans 1935, 938-42). This scene was overdramatised further by Pendlebury (1939, 23I), who stated that: 'it looks as if the king had been hurried here to undergo too late some last ceremony in the hopes of saving the people'.

The presence of the alabastra and their involvement in an anointing ceremony have been very influential in Aegean scholarship and are often mentioned as additional 'supporting evidence' for the room's ritual function (Hägg 1988 for a summary). There is no doubt that the number of stone alabastra said to have been found in that room is exceptional (possibly I2 with three lids) (Arbin 1984). How these objects were actually used, however, is more problematic (on the problems involved in associating the Throne Room with anointing ceremonies, see Waterhouse I988, 365-6). It suffices to say here that Evans's several plans of the Throne Room, marred with inconsistencies and post-excavation additions and the problematic find-spots of the various objects found therein, should make us wary of taking the anointing ceremony as a 'fact' (e.g. compare Fig. 3I $a$ and Fig. 3I $b$ ).

The broken pithos, the scattered alabastra and the objects found in the lustral basin actually appear to speak more in favour of post-destruction deposition than of an organised ceremony. ${ }^{6}$ Originally called 'pithos on side' (in Evans's I900 notebook), this item was only later relabelled (and reinterpreted) as an 'overturned oil jar'. The four alabastra originally surrounding the pithos in the 1900 notebook drawing (Fig. 3Ia) were later moved in front of or near the mouth of the jar to strengthen further the 'anointing ceremony' idea of Evans. 47

Setting the anointing ceremony to one side as problematic, to say the least, the other most pervasive idea with regard to the function of the Throne Room is the one first proposed by Helga Reusch - that this room was the site of a cult of epiphany centred on a female figure (Reusch 1958, 334-58, based on the reconstructed heraldic arrangement of the griffins on the north wall and other iconographic parallels; also Reusch I96I; 1965). This idea was supported by Mirié and was expanded further by Niemeier, who connected the nearby Service Section rooms to the re-enactment activities that took place in the complex (Mirié I979; Niemeier I986; I987; also Goodison 200I). Marinatos linked the lustral basin to the re-enactment activities, speculating further that the small finds found in the basin were part of offering ceremonies (Marinatos I984b, 6I-84; I993, I08). However, the 1987 investigation in the areas to the north

46 Evans's I900 plan of the Throne Room was published in Hägg I988, fig. 2; for later drawings see Evans I92 I, 5, fig. I; 1935, between 902-3, fig. 877, and the drawing (probably in preparation for Palace of Minos IV) now at the Ashmolean, without a number, stored with other plans and cut-outs in preparation for The Palace of Minos volumes in a plan chest in the Arthur Evans Archive, Ashmolean Museum, University of Oxford.

47 E.g. in Evans I92 I, 5, fig. I, three alabastra are shown, while in Evans I935, between 902-3, fig. 877, five alabastra are shown near or in front of the mouth of the 'overturned oil jar'; an alabastron and 'traces' (circular markings) of five more alabastra are added to the 1935 plan. 


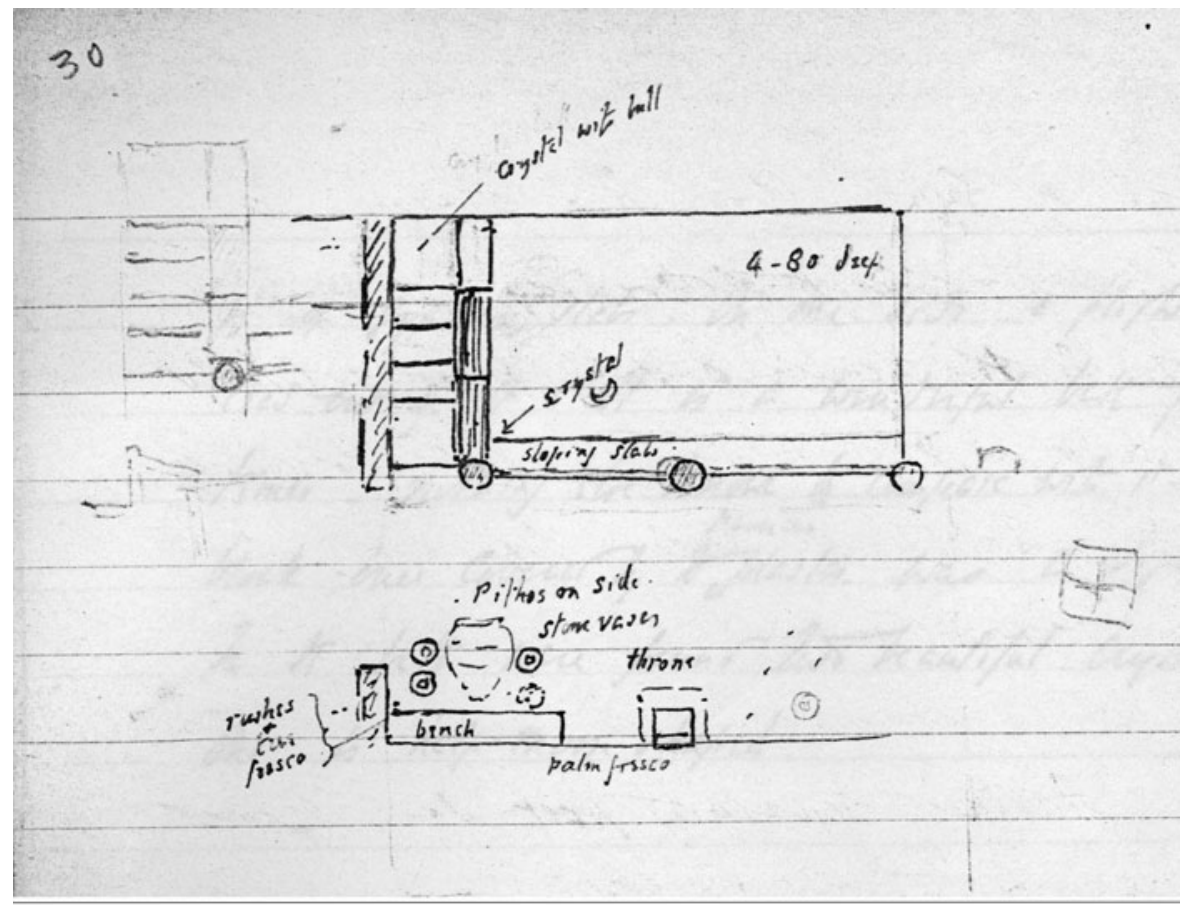

(a)

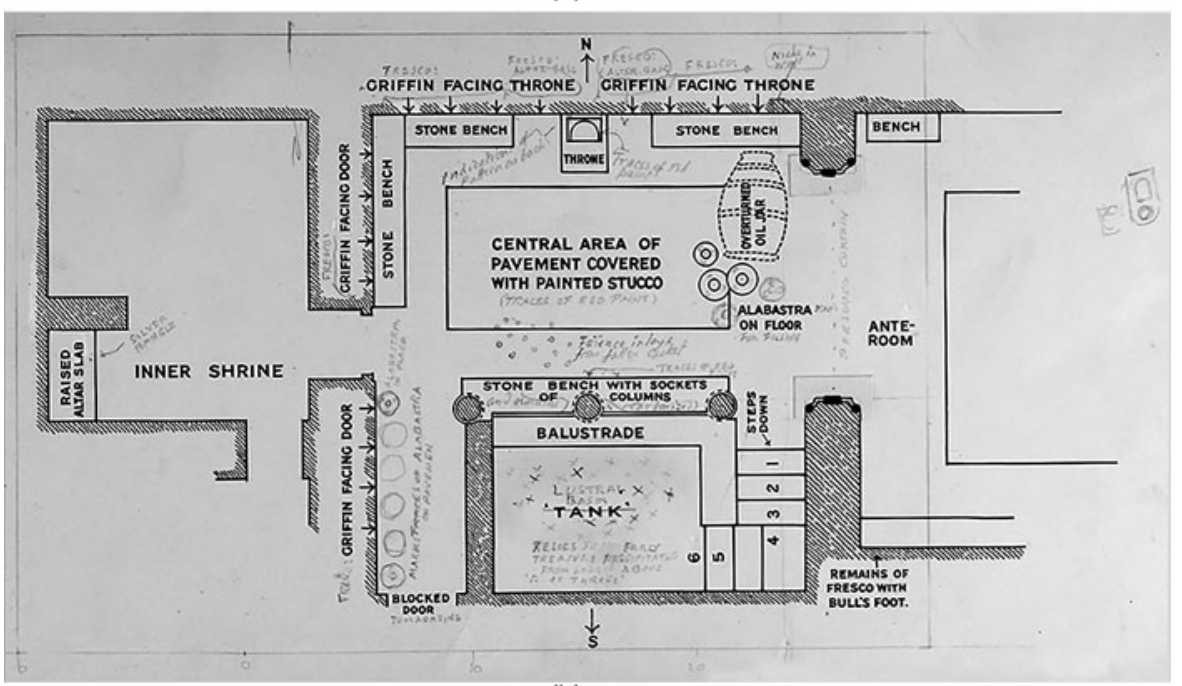

(b)

Fig. 3I. (a) Plan of the Throne Room with find-spots in the course of excavation. $A E / N B$ I900, I2 April, 30; (b) Plan of the Throne Room with annotations by Arthur Evans, probably in preparation for The Palace of Minos (Evans I92I, 5, fig. I), print annotated in ink without an archival number.

Courtesy of the Arthur Evans Archive, Ashmolean Museum, University of Oxford.

and west of the Throne Room suggests that there was no opening on the wall between rooms 44 and 45: the opening as seen today was entirely constructed by Evans and does not correspond to an original arrangement, nor does it indicate an original state as suggested by Mirié (Figs 2, 3). $4^{8}$ Although this development cannot altogether discount or support the presumed 'epiphany ceremonies' taking place in the Throne Room, it certainly removes from the equation the direct

48 We would like to thank Vasso Fotou and Doniert Evely for this information. For a full discussion on the alleged opening 44/45, see chapter I.2 in Hood, Fotou and Evely forthcoming. 
connection of the Service Section area with the 'inner sanctuary' (e.g. Hiller I996a, who does not ascribe an exclusively ritual function to the Throne Room).

Of interest in this respect is the 'interactive' relationship that all these scholars saw between the figure on the throne, or in the door of the 'inner sanctuary', and the surrounding painted images - a relationship that still occupies discussions in Aegean archaeology with regard to ideology and iconographies of power. John Bennet described the heraldic arrangement of the griffins, together with the 'altar-base(s)' and the palm(s), as acting as a 'static 'frame', a 'focalising device for the physical presence of an individual', thus creating an 'inclusive' or 'participatory' space, 'where life-size or near life-size representations invite live actors to participate with the images depicted on the walls' (Bennet 2007, I2; the term 'inclusive' comes from Renfrew 2000, I40-3).

The concept of divine power was, in this way, visualised by creating a 'first-person' iconography of power, different from the contemporary 'third-person' representations of the East Mediterranean (Bennet 2007, I2-I3; see also Panagiotopoulos 2012, 73-4). With a similar idea in mind, Hiller argued that the throne and its occupant were placed within an Egyptian-inspired Elysian field of palms, papyrus-reed hybrids, griffins and a riverine landscape (interpreting the undulating bands as standing for 'river') (e.g. Hiller I996b; Hiller 2008; also Warren 2007; the riverine interpretation [undulating hills and river] was actually first presented by Evans I899-I900, 40; cf. Niemeier 1986, 88). Similarly, the couchant wingless griffins set in a lush landscape of papyrus-reed hybrids, on either side of the door leading to the 'inner sanctuary' could well have been meant to guard, in a strongly 'Egyptianising' fashion, the entrance and accompany such an 'enacted epiphany' (with the performer/priestess hiding in the 'inner sanctuary' and only 'appearing' at the appropriate moment of ceremony). 49

It is, however, very difficult to determine with any clarity the function of the 'inner sanctuary' room during LM II-IIIA, let alone whether our concept of a Minoan 'epiphany' was indeed performed in the Throne Room at all. It is necessary to bear in mind that most ideas that have been written about Minoan epiphanies are heavily based on ritual cycles depicted in the art of the Neopalatial period alone (Matz 1958). Although the Throne Room fresco clearly has its roots, as shown here, in Neopalatial imagery, its LM II date of composition exhibits enough peculiarities to make us aware of the possibility that the new approach chosen to present the occupant of the throne also included changes in the structure of the rituals located in that space.

We should exercise the same caution when we try to identify the occupant of the Knossos throne in LM II-IIIA, and whether it was a woman or a man. For some scholars, the person who sat on the throne was a priestess presiding over fertility and/or chthonic rituals (Reusch 1958; 196I; I965; Cameron 1976; Marinatos 1984a; 20I0; Niemeier 1986; 1987; Rehak 1995; Rethemiotakis I995; cf. Nilsson 1950, 284-5); others saw the stone seat as more fitting for a ruler or a 'Priest-King' (Evans 1935, 90I-36; Hiller 2006; Maran and Stavrianopoulou 2007).50 Other interpretations consider the stone seat an aniconic symbol (Hitchcock 20I0) or an important element in the alignment of the Throne Room to create specific lighting effects at dawn at certain times of the year (Goodison 200I). While the throne and the two adjoining rooms are often considered as the most sacred complex area of the palace at Knossos (e.g. Goodison and Morris 1998, I23-4), others challenge the connection of the Throne Room exclusively with cult (e.g. Hiller I996a). It is indeed possible that the room changed functions over time, from the first to the second half of

49 Lambert's I9I7 reconstruction (Fig. 23) includes the Boston (snake) goddess (which 'surfaced' in I9I4) on a shelf in the 'Inner Sanctuary'. Since Lambert quite certainly did not add this off his own bat, it rather suggests that the idea of such 'epiphany' in relation to the Throne Room was originally an idea ( $s c$. fantasy in this case) of Evans's. Cf. Matz 1958, I6-I7, 37, who interpreted the gesture of the 'snake goddess' as expression of her 'sudden appearance' in a visionary epiphany; and Niemeier 1986, 77, 83, who correspondingly located an enacted epiphany in the western door opening of the Throne Room.

50 Despite the overwhelming evidence for enthroned figures being women, not men (as discussed by Rehak I995), Bennet (2007, I3, n. I6) notes that such depictions may well have been idealised, perhaps because 'depicting the male ruler in a seat was an event only enacted, not depicted'. Whenever a female is thus represented it may either refer to a divine or mythical figure or idealisations of the divine power 'behind the throne' according to Bennet. On the 'absence' of the ruler in Late Bronze Age Aegean representations see Davis 1995 and Shelmerdine 1999. 
the second millennium BC, as already proposed by Niemeier (1987, I66-7; also Mirié 1979; Begg I987, I84; Macdonald 2005, 216-17), and that the iconography of the room acted as originally supporting re-enactment ceremonies ('priestess'-'goddess') with griffins and floral decoration as the setting of these performances, only to become later the setting for the power and ideology of the LM II ruler or rulers of Knossos.

In our view, the development of the LM II composition can best be approached and understood by placing it within the architectural and ritual history of this area. The decoration of the Throne Room in LM II took place within the socio-political horizon of Knossos trying to establish its new role on the island following the widespread destructions at the end of LM IB. ${ }^{\text {I }}$ It was also part of a broader iconographic 'programme' that included other important parts of the palace, like the West Porch and Corridor of the Procession Fresco and the polythyron halls in the East Wing. On the one hand, the Throne Room fresco shows continuity in the way the image of the throne and its occupant was constructed along the lines of Neopalatial imagery of ritual foci and enthroned/ seated (female) figures. In this respect, the role and image of the seated figure were retained perhaps even together with the throne and benches, ${ }^{52}$ and with the lustral basin, whether in use or not in LM II - but embedded into a new construction and understanding of the room and its function as a place of ritual activity.

The date of construction of the lustral basin is at present unclear, though a Neopalatial date seems plausible to us. Vasso Fotou has kindly informed us (pers. comm. 29 July and 3 September 20I6) that she found no evidence that a room of the lustral basin type occupied this spot before LM II, and no evidence that the lustral basin was filled in during the same period. Evans (1928, 522) was the first to suggest that the lustral basin was 'paved over' in LM II. Mirié ( 1979,77 ) put forward the idea of the lustral basin having been filled in without, however, substantiating it. Niemeier (1987, I67) adopted this idea on the basis of fragments of a stone rhyton found scattered in the deposit. These fragments do not prove that the part below the adjacent floor was filled in, especially since we do not know their exact position in the deposit. Macdonald (2005, II6 with note) has pointed out most recently that

when excavations began at Knossos, the diggers tended to carry on down to the first solid floor. In this instance, the first good floors would have been the New Palace floor of the Room of the Throne and the deeper one of the lustral basin. A later earth or plaster floor over the basin could well have been missed.

A functional lustral basin in LM II would have indeed been exceptional - but then again, the whole iconography and arrangement of the Throne Room is extraordinary, making the presence and functionality of the basin all the more intriguing in a LM II context. On the other hand, the

5I One of the major outcomes of the 2007 LM IB pottery workshop (Brogan and Hallager 20II) was the possible identification of several sub-phases of LM IB, despite the difficulty of synchronising them between sites. Moreover, and despite the fact that LM II pottery is still not completely understood and is only documented in certain sites on the island, several scholars raise the possibility of overlapping the final stage of LM IB with LM II (also MacGillivray's suggestion 2009, I69) - and in the case of Knossos, the stylistic 'switch' appears to have happened in 'rapid succession' (Hatzaki 20II, 83). This rapid transformation and possible overlap may help us understand further the blending of LM IB and LM II elements in the Throne Room composition.

52 Krzyszkowska 1996, in her detailed discussion of furniture in the Bronze Age Aegean, considered the throne Neopalatial in style, though she admits the difficulty in dating it. Rehak 1995, 97-8 also argued in favour of a possible Neopalatial date and compared the undulating edge of the throne to a similar-looking object above the top of the shrine facade of the Sanctuary rhyton from the palace at Zakros. Platon (I95I) advocated a LM II date for all these thrones. We may now add the depiction of a 'throne' on one of the smaller rings from the recently unearthed LH II 'Griffin Warrior' tomb at Pylos: with its tall back, spandrels and side stretchers, it resembles the throne in the Throne Room as seen from the side, thus corroborating a LM I date for the stone seat in Knossos (Davis and Stocker 2016, 645-6, with fig. I2). As for the benches, the best parallels come from the LC I (LM IA) Xeste 3 at Akrotiri (Palyvou 2005, 58, fig. 69, and I53), LM IA Ayia Triada ('room of benches', East Wing), and Phaistos ('sentry box' at south end of Corridor 4I, to the west of the Central Court [Cameron I976, vol. 3, I22, pl. I42]). 
stylistic rendering of well-known visual elements in the Throne Room fresco - from the wingless and florally ornamented beasts and the cut-out-style incurved bases to the red-coloured palm tree and the continuous 'veined stone' dado - provides us with a convincing hint at the attempt to create a totally new and formerly unseen impression of the room and its occupant. Even though the throne and its setting may have continued the 'tradition' of Neopalatial enthroned/ seated figures, the way the decorative programme was delivered in LM II also reveals a conscious effort to break with old practices. This 'subversion/appropriation' of Neopalatial art and architecture - if we are to interpret LM II developments across the palace as such - may have formed part of an attempt to blend various visual elements and create a 'new image of power': one that supported a new ideology, that of the wanax.

Maran and Stavrianopoulou (2007, 289-92) have recently built on the work of Reusch (1958; I96I; 1965), Niemeier (1986; 1987) and Rehak (1995) by suggesting that the wanax ideology possibly had Cretan roots (also Renfrew 1998, 250-2; on the term and its origins, see also Palaima 2006; 2016). This idea is particularly appealing given the blending of elements identified in the representation of the 'palm fresco' and of the composition of the Throne Room as a whole and the references made to the (not-so-distant in every respect) Neopalatial past. For Maran and Stavrianopoulou, the assumed transformation of this ideology took place early in LM IIIA2 (based on a LM IIIB date for the firing of the Linear B documents and the final destruction of Knossos). Contra Reusch and Rehak, the two scholars observed that irrespective of the existing iconography which frequently shows female figures in this dominant position, one cannot exclude the possibility that depending on the occasion a man ('king') or a woman ('queen' or a divine representative) could have occupied the seat and presided over rituals - an aspect which, according to Maran and Stavrianopoulou, was central within the wanax ideology. Their contribution is indeed important, as it recognises inspiration drawn from the Neopalatial past. We would, however, argue that this ideological transformation had many stages - one of which we may be witnessing with the LM II iconography of the Throne Room. The importance attached to this room and its decorative programme may well have influenced subsequent representations which adopted, adapted and modified these images of power (e.g. to suit the needs of the mainland ruling elites).

Given that the iconography of the Throne Room at Knossos finds its best artistic comparanda during the LM I-II periods, and given that the construction of the room itself was the result of the remodelling of this sector of the palace early in LM II, we would like to bring this suggestion forward in time and speculate a LM IB-II date for the formation of this ideological blending and the beginning of a wanax ideology in art. In our view, the particular adherence to Neopalatial concepts of elite ritual - including the visual language to centre-stage the throne and its occupant and the further expression of his/her status by pairing him/her with fantastic creatures like the griffin - could add weight to the idea that the driving force behind the LM II remodelling of the Throne Room, and large parts of the Knossian palace, may have been the local elite.

This blending of traditions for the creation or reinterpretation of images of power fits well with the context of LM II-IIIA Crete, a time when Cretan and exogenous traditions come together in an attempt to form dynamic social tools in the material vocabulary of the island's elites - as observed in a number of media and contexts: from pottery to tomb architecture and burial furnishings to elite iconography (Preston 1999; 2004; also various articles in Driessen and Farnoux 1997). Contrary to the still-dominant idea of a takeover of Knossos by mainlanders (but see the nuanced interpretation of Wiener 2015, I4053), we understand these developments as signs of spiralling competition between local elites, among which the Knossian elite gained the upper hand throughout LM II to IIIA2 early, i.e. the period during which we would place the dating of the Linear B documents from Knossos (this, now widely accepted, date is due to Popham 1970; for a summary of the problems surrounding the dating of the Knossos tablets and of the theories around the changes that took place from LM IB to LM II, see Fidio 2008, 93-6; also Driessen

53 For the idea of a putative Knossos-Mycenae 'special relationship' see Dickinson 1996, 70. 
and Macdonald 1997).54 That these elites might have been cosmopolitan in nature should not be excluded - what is more important, for us at least, is that the power drive in LM II appears Knossian-formed and Knossian-based, irrespective of the 'ethnic' or linguistic composition of its instigators.

With the possible rise of the wanax within no more than a few decades from the end of LM IB and beginning of LM II, it could well be that the decoration of the Throne Room served the creation of a renewed ruling environment in which a high official now, or soon after, called the wanax already existed and had important leading functions. 55 The wanax ideology then made use of visual imagery to accompany and perhaps justify this new model of power based on sole rulership, along with his entourage that helped support this power. Within this model, we see divine permission or blessing as necessary for the wanax to legitimise his position within this 'new order' - at a time when Knossos appears to have established itself as the one and only centre of power on Crete (Bennet I990).

In this process, the wanax could have instrumentalised the (still female?) occupant of the Throne Room, who, accompanied by wingless griffins, made her appearance in the entrance from the 'inner sanctuary' and took her seat on the throne. The scenario of the wanax actually sitting next to the Central Court and having the support of a priestess/goddess impersonator literally 'backing' him from the 'Throne Room' proper looks appealing in the context of the charred finds that Evans discovered in the anteroom (where another - wooden? - throne may once have stood ${ }^{56}$ ). The animals standing beside the priestess/goddess can be seen as 'guardians' or a 'voluntary' entourage, in a similar manner to the contemporary 'goddess with snake frame' scenes, 57 where sometimes pairs of winged griffins, and sometimes also pairs of lions, are disciplined and controlled. ${ }^{8}$ The growing prominence of the 'goddess with snake frame' in the Final Palatial period could well represent the role and importance of the (female) occupant of the Throne Room in the legitimisation of the wanax from LM II onwards.

Based on the important location of the Throne Room within the palace complex, its elaborate layout and decoration and its significance as one of the most key locales at Knossos and also the 'focalising device' of the fresco composition, we would argue that whatever other functions the room may have performed or supported over its long history, one of them was to highlight an important individual in LM II-IIIA.59 Iconographically, the Throne Room was well designed during this period to host a leading figure equipped with or linked to divine power, though in the end we will probably never know whether this was a king, a priest-king, a high-priest, an impersonated god, a queen, a high-priestess, or an impersonated goddess, or any of the above.

54 Other scholars, however, are of the opinion that the changes between LM IB and LM II should be regarded as essentially a continuation of 'Minoan' culture, 'the last great flourish of Minoan "palatial” civilization' (Fidio 2008, 94) with Knossos in a hegemonic role (see e.g. Hallager I978, Niemeier I982; I985, 217-3I; Hiller I987). Although for these scholars the 'Mycenaean domination of Knossos' and of the rest of the island would be placed in LM IIIA2B, there are those (Hallager I977, 94) who see mainlanders already at Knossos from LM II to IIIB.

55 Could this 'high official' be the man dressed in a hide skirt dress covering the arms and shoulders, with or without the snake frame as his insignia of power? See Lebessi, Muhly and Papasavvas 2004 and discussion in Marinatos 2010, 32-49.

56 The stone platform now under the wooden replica does not appear in the archival photographs and is not mentioned in the notebooks (contra Marinatos 2010, 55, fig. 4.5). The presence of a second throne is conjectural.

57 Unlike e.g. the Neopalatial 'Master/Mistress of Animals' scenes, where the creatures are subdued by the central figure. A 'goddess with snake frame' can coexist with winged griffins and 'altar-bases': CMS V no. 669 and CMS XIII no. 39.

58 We interpret the 'snake frame' as a symbol of power of some sort. In the Neopalatial period, it seems to have been carried as a ceremonial or status object signifying political and/or religious power. A 'snake frame' (or 'bull horns' or 'horned bow'), crowned with double axes, is carried by a man in a LM IA procession scene from Xeste 4 at Akrotiri (Boulotis 2005, 30-I; Marinatos 2010, I77) and on the gold signet rings from Kato Syme and ElatiaAlonaki (Lebessi, Muhly and Papasavvas 2004 and CMS V Suppl. 2, no. I06).

59 The Throne Room composition, however, was not unique in the palace, as suggested by the fragments painted in ochre, mentioned above, and also the fragment of a griffin noted by Cameron (1976, II2, pl. I30 $A$ ). Other rooms may therefore have had a similar pictorial programme for 'staging' the same, or another central, person elsewhere in the palace. 
Perhaps this elusiveness reflects the fluidity in the ideological components of the wanax ideology at this early stage of development: a development that can also be viewed as a transformation of the pre-existing power forms, with an attempt to suggest 'continuity' based on the maintenance of the 'allusive' and the 'polysemic' - elements that may have formed a crucial part of the expression of power in the Neopalatial period (Whittaker 2015). ${ }^{60}$

\section{CONCLUSION}

It may have seemed like a very long journey in the sense that our research ended where it more or less started: with the date first put forward by Arthur Evans and Duncan Mackenzie regarding the construction and decoration of the Throne Room in LM II. The I987 excavation confirmed Evans's, and Mackenzie's, conclusion that this area - the 'West Central insula (North)' - was indeed a LM II intrusion, 'a tabula rasa' (Evans 1935, 888; we thank Vasso Fotou and Doniert Evely for discussing this point with us). Yet a lot has changed since the days of Evans and Mackenzie, not only in terms of the palace's long and complex history, our understanding of stratigraphic sequences, and the theoretical maturity of Aegean archaeology, but also of our specific knowledge on the actual fresco fragments found in April 1900. With this contribution we tried to establish the date of the composition, integrate all extant archival information with the actual archaeological remains and reconstruct - to the extent possible - the artistic 'tradition' of the scenes that adorned the walls of the Throne Room, and assess the implications stemming from this decorative programme for better understanding LM II Knossos. We would like to conclude with a brief summary of our main interpretation.

We started with the conservation of the 'palm fresco', hidden for almost a century in the storage room of the Herakleion Museum. This fragment shows a Neopalatial-style palm bearing immature fruits, completely red instead of the usual Neopalatial blue-leaved tree; underneath, an incurved 'altar-base', clearly drawing inspiration from Neopalatial examples, but, with its 'cut-out' style, also looking different in terms of its use from the known corpus of frescoes from that period. The scene is completed with a 'veined stone' pattern, equally impressive in its innovative execution, colours and overall rendering, that, rather than aspiring to imitate stone veneering, served to corroborate the focalising effect of the whole composition enclosing the throne and its occupant.

Our conservation project also included the griffin frescoes from the west wall. As with the 'palm tree' fresco, here too the Neopalatial ancestry of the griffin in its role as a guardian animal appear to have merged in LM II with the novelty of its rendering: a wingless creature with floral ornamentation - a true Herrschaftsemblem according to Blakolmer's (2OII) interpretation. It is this spirit of innovation, on the one hand, and of signs of Neopalatial conservatism, on the other, that makes the 'palm fresco' and the Throne Room composition as a whole one of the most significant moments in the history of Aegean art.

The long-forgotten section on the north-east wall of the Throne Room, still in situ, helped to understand the balanced composition of the landscape embracing the palm tree and the griffins, setting the scene for people and actions in this space. This sense of symmetry and balance appears to be supported further by the placement of griffins and plants on either side of the entrance to the 'inner sanctuary'; and in such details as the mirrored slanting of the 'veins' on either side of the throne and the similar position of the benches on both sides.

The best way to understand the blending of 'conservative' and 'innovative' elements in the decorative programme of the Throne Room is within the context of social and political changes in LM II Knossos and Crete as a whole. Placed in a familiar setting, artistically and perhaps also

60 The social structure of Neopalatial societies remains, however, a matter of debate. For the idea of the 'palace' in Neopalatial Minoan society as a communal building without a primary political and residential function, but still serving as the main political arena, see Driessen 2002 with additional references. 
literally in the presence of supernatural creatures, both predators and attendants, the ruling elite of Knossos developed a new artistic language to promote and possibly legitimise its power - in our view a Knossian-based and Knossian-shaped power that drew inspiration from the not-so-distant Neopalatial past. Could we have here an attempt to claim continuity and legitimacy from the ancien régime to the new political reality? Could the blending (or subversion) of traditions have facilitated the blending of divine power with politics, if they were not already indistinguishable? Within this framework, the throne itself may have been subverted from earlier iconographic cycles to serve the LM II ruling ideology, if it was not in itself a product of Neopalatial craftsmanship. A similar interpretation (but pro-Mycenaean this time) has been suggested by Driessen and Langohr. They note that "the "throne room" does not turn the Knossos building into a Mycenaean palace either culturally or ethnically ... It remained, or rather was turned into, a typical "Minoan" monument that now served as the hub of a newly established state system' (Driessen and Langohr 2007, I84). This subversion was made, in their view, by the new ruler of Knossos in an attempt to legitimise his claim as a rightful heir to the Minoan traditions.

Whether these changes took place under mainland control or that of a cosmopolitan, localbased elite (as is our view), the 'audience' to which this iconography of power was predominantly directed was the local population and only later the mainland elites. What we may be witnessing, then, in the LM II Throne Room at Knossos is yet another episode in the transformation and subversion of material culture, and of images in particular, in the service and support of the power of the ruler and his entourage, with floral and faunal hybrids creating the necessary idealised backdrop. ${ }^{6 \mathrm{I}}$ The result is an image and composition that looks to the (notso-distant) past for inspiration in an attempt to create something new - a different image of power for the consolidation of Knossos' sole rulership on Crete, and part and parcel of the rising ideology of the wanax.

\section{ACKNOWLEDGEMENTS}

This paper grew out of a collaboration between the Ashmolean Museum, University of Oxford, and the Archaeological Museum in Herakleion. The first results of this collaboration were presented at the IIth International Cretological Conference, 2 I-7 October 20I I, at Rethymno, Crete. The study of the 'palm fresco' was supported by a generous grant from the Arthur Evans Fund (Ashmolean Museum) and the Craven Committee, University of Oxford. Additional financial support came from the Faculty of Classics and Sidney Sussex College, University of Cambridge. For permission to study the decorative programme in the Throne Room at Knossos, and any relevant archival documentation, we are most grateful to Dr Giorgos Rethemiotakis, Dr Stella Mandalaki and Dr Athanasia Kanta (Herakleion Museum permits: (a) the Palm Fresco: 8/8/ 20II, prot. no. I857; (b) panel with fragments from north part of west wall: 09/12/2013, prot. no. 4239); and Dr Susan Walker and Dr Paul Roberts (Ashmolean Museum). We would also like to extend our most heartfelt thanks to Pepi Stefanaki for her excellent drawings and to Yannis Papadakis for photography carried out in the Herakleion Museum; and to the IESLFORTH for the analysis of the fresco fragment (Herakleion Museum permit, 20/7/20I2, prot. no. 2462). We are most grateful to Dr Vasso Fotou and Dr Doniert Evely for sharing with us their important data from their forthcoming publication; and to Professor Diamantis Panagiotopoulos and Dr Maria Anastasiadou for allowing us to reproduce several CMS drawings. We would also like to thank Matthew Potter, who did the artwork of the 'Throne Room' in the Aegean World gallery at the Ashmolean, and the staff of the Libraries in Oxford, Cambridge, Heidelberg and Cincinnati for making available to us their outstanding collections. Special thanks to Amalia Kakissis for facilitating access to the Mark Cameron Archive in the

61 For the religious associations of the Throne Room with the ruling 'Mycenaean' ideology see also Niemeier I 987 and Whittaker 200I, 359. 
British School at Athens and to Michael Loy for his invaluable help with text editing. For their multifaceted help, we are also grateful to Professors Peter Warren, Jack Davis, Clairy Palyvou and Andreas Vlachopoulos, Dr Ann Brysbaert, Dr Eleni Hasaki, Dr Emily Egan, Dr Georgia Flouda, Dr Alexandra Livarda, Dr Constanze von Rüden, Dr Elizabeth Shank, Dr Susan Sherratt, Dr Sharon Stocker, Eirini Galli, Katerina Athanasaki, Helen Hughes-Brock, Carol Hershenson, Nikos Sisamakis and Jevon Thistlewood. We also thank the three anonymous BSA reviewers who made important suggestions that helped improve our paper; and Peter Liddel for his patience with the editing process. Any errors or omissions remain with the authors.

ig298@cam.ac.uk

\section{REFERENCES}

\section{Unpublished Sources}

$A E / N B=$ Notebooks describing the excavations at Knossos and other sites in Crete by Arthur Evans, Ashmolean Museum, University of Oxford.

$C A M=$ Mark Cameron Papers, British School at Athens.

$D M / D B=$ Daybooks by Duncan Mackenzie with sketches and plans describing the excavations at Knossos, Ashmolean Museum, University of Oxford.

$K n D r A=$ I. Drawings, i.e. plans, sections, elevations, and isometric and perspective views of the architectural remains at Knossos, as found and/or as restored; II. Drawings of frescoes and pottery found at Knossos. Ashmolean Museum, University of Oxford.

PhEvans $=$ Photographs of the excavations at Knossos and other sites by or taken for Arthur Evans, Ashmolean Museum, University of Oxford.

\section{Published Sources}

Antognelli, N. 2006. 'La palma e l'immaginazione del mondo esotico. Recezione e interpretazione di un motivo nelle raffigurazioni egee del Tardo Bronzo', NumAntCl 35, II-29.

Antognelli Michel, N. 20I2. 'Palms and papyruses in the Late Minoan/Helladic III: the Exotic World, the Fantastic World and the Afterworld', in Stampolidis, N.C., Kanta, A. and Giannikouri, A. (eds), Athanasia: The Earthly, the Celestial and the Underworld in the Mediterranean from the Late Bronze and the Early Iron Age. International Archaeological Conference, Rhodes, 28-3I May, 2009 (Herakleion), 4I-52.

Arbin, H. von 1984. 'The alabastron-shaped vases found in the "Throne Room" at Knossos', OpAth I5, 7-I6.

Begg, D.J.I. I987. 'Continuity in the west wing at Knossos', in Hägg, R. and Marinatos, N. (eds), The Function of the Minoan Palaces. Proceedings of the Fourth International Symposium at the Swedish Institute in Athens, IO-I6 Fune, 1984 (Stockholm), I79-84.

Bennet, J. I990. 'Knossos in context: comparative perspectives on the Linear B administration of LM II-III Crete', $A \mathcal{F} A$ 94:2, I93-2I2.

Bennet, J. 2007. 'Representations of power in Mycenaean Pylos: script, orality, iconography', in Lang, F., Reinholdt, C. and Weilhartner, J. (eds),

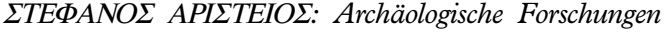

zwischen Nil und Istros, Festschrift für Stefan Hiller zum 65. Geburtstag (Vienna), II-22.

Betancourt, P.P. forthcoming. 'Evidence from pottery for the early stages of monumental Cretan wall paintings', in Vlachopoulos, A.G. (ed.), $X P \Omega \Sigma T H P E \Sigma$. Wall-painting and Vase-painting of the 2nd Millennium BC in Dialogue (Athens).

Bietak, M., Marinatos, N. and Palyvou, C. 2007. Taureador Scenes in Tell El-Dab'a (Avaris) and Knossos (Vienna).

Blakolmer, F. 20II. 'Vom Thronraum in Knossos zum Löwentor von Mykene. Kontinuitäten in Bildkunst und Palastideologie', in Blakolmer, F., Weilhartner, C., Reinholdt, J. and Nightingale, G. (eds), Österreichische Forschungen zur Ägäischen Bronzezeit 2009 (Vienna), 63-80.

Blakolmer, F. 2013. 'Die Farbe Rot in Symbolik, Bildkunst und Sprache der bronzezeitlichen Ägäis', in Meller, H., Wunderlich, C.H. and Knoll, F. (eds), Rot - Die Archäologie bekennt Farbe (Tagungen des Landesmuseums für Vorgeschichte Halle io; Halle), 275-86.

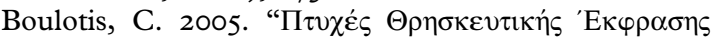

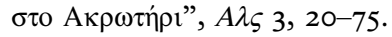

Bradshaw, J.M. and Head, R.J. 20I2. 'The Investiture Panel at Mari and rituals of divine kingship in the ancient Near East', Studies in the Bible and Antiquity 4, I-42.

Brogan, T.M. and Hallager, E. (eds) 20II. LM IB Pottery: Relative Chronology and Regional Differences (Monographs of the Danish Institute at Athens II: I-2; Athens).

Brown, A. 2000. Arthur Evans and the Palace of Minos (Oxford).

Bruyère, B. I959. La Tombe No. I de Sen-nedjem à Deir el Médineh (Cairo).

Bruyère, B. and Kuentz, C. 20I5. Tombes thébaines. La nécropole de Deir el-Médineh, La tombe de NakhtMin, La tombe d'Ari-Nefer (Cairo).

Brysbaert, A. 2008. The Power of Technology in the Bronze Age Eastern Mediterranean. The Case of the Painted Plaster (London).

Bunson, M. 2002. Encyclopedia of Ancient Egypt (New York)

Cameron, M. I968. 'Unpublished paintings from the "House of the Frescoes" at Knossos', BSA 63, I-3I.

Cameron, M.A.S. I970. 'New restorations of Minoan frescoes from Knossos (summary)', BICS I7, 163-6. 
Cameron, M.A.S. 1976. 'A General Study of Minoan Frescoes' (unpublished $\mathrm{PhD}$ thesis, University of Newcastle-upon-Tyne).

Cameron, M.A.S. I987. "The "Palatial" thematic system in the Knossos murals. Last notes on Knossos frescoes', in Hägg, R. and Marinatos, N. (eds), The Function of the Minoan Palaces (Stockholm), 320-8.

Cameron, M.A.S., Jones, R.E. and Philippakis, S.E. 1977. 'Scientific analyses of Minoan fresco samples from Knossos', $B S A$ 72, I2 I-84.

Catling, H.W. (ed.) I987-8. 'Complex of rooms behind the Throne Room', $A R$ 34, 68.

Crowley, J.L. 1989. The Aegean and the East. An Investigation into the Transference of Artistic Motifs between the Aegean, Egypt, and the Near East in the Bronze Age (Studies in Mediterranean archaeology and literature. Pocket-book 5I; Jonsered).

Danthine, H. I937. Le palmier-dattier et les arbres sacrés (Paris).

Davis, E.N. I974. 'The Vapheio Cups: one Minoan and one Mycenaean?', ArtB 56, 472-87.

Davis, E.N. I995. 'Art and politics in the Aegean: the missing ruler', in Rehak, P. (ed.), The Role of the Ruler in the Prehistoric Aegean (Aegaeum II; Liège and Austin), II-22.

Davis, J.L. and Stocker, S.R. 20I6. 'The Lord of the Gold Rings: the griffin warrior of Pylos', Hesperia $85: 4,627-55$.

Dawkins, R.M. I945. 'The cultivation of the date-palm in Minoan Crete', Man 45, 47.

Day, J. 2012. 'Caught in a web of a living world: treehuman interaction in Minoan Crete', $P A N$ : philosophy activism nature 9, I I-2 I.

Dickinson, O.T.P.K. I996. 'Minoans in Mainland Greece, Mycenaeans in Crete?', Cretan Studies 5, 63-7I.

Dimopoulou, N. and Rethemiotakis, G. 2004. The Ring of Minos (Athens).

Dimopoulou-Rethemiotaki, N. 2005. The Archaeological Museum of Herakleion (Athens).

Dorman, P.F. I99I. The Tombs of Senenmut. The Architecture and Decoration of Tombs $7 I$ and 353 (New York).

Doumas, C. I999. The Wall-paintings of Thera (Athens).

Driessen, J. 2002. "“The King Must Die." Some observations on the use of Minoan court compounds', in Driessen, J., Schoep, I. and Laffineur, R. (eds), Monuments of Minos. Rethinking the Minoan Palaces (Aegaeum 23; Liège and Austin), I-I4.

Driessen, J. and Farnoux, A. (eds) I997. La Crète mycénienne: Actes de la Table Ronde Internationale organisée par l'École française d'Athènes (26-28 Mars I99I) (BCH Suppl. 30; Athens).

Driessen, J. and Langohr, C. 2007. 'Rallying 'round a "Minoan" past: the legitimation of power at Knossos during the Late Bronze Age', in Galaty, M.L. and Parkinson, W.A. (eds), Rethinking Mycenaean Palaces II, and edn (Cotsen Institute of Archaeology at UCLA Monograph 60; Los Angeles), I78-89.

Driessen, J. and Macdonald, C.F. 1997. The Troubled Island: Minoan Crete Before and After the Santorini Eruption (Aegaeum I7; Liège and Austin).

Evans, A.J. I899-I900. 'Knossos, I. The Palace', BSA $6,3-70$.
Evans, A.J. I90I. 'Mycenaean tree and pillar cult and its Mediterranean relations', $\mathcal{H} H S$ 2 I, 99-204.

Evans, A.J. I921. The Palace of Minos, vol. I (London). Evans, A.J. 1928. The Palace of Minos, vol. 2 (London). Evans, A.J. I930. The Palace of Minos, vol. 3 (London). Evans, A.J. 1935. The Palace of Minos, vol. 4 (London). Evely, D. I999. Fresco: A Passport into the Past. Minoan Crete through the Eyes of Mark Cameron (Athens).

Fidio, P. de 2008. 'Mycenaean history', in Duhoux, Y. and Morpurgo Davies, A. (eds), A Companion to Linear $B$ (Mycenaean Greek Texts and their World. Vol. I; Leuven), 8I-II4.

Foster, E.D. I977. 'Po-ni-ki-jo in the Knossos tablets reconsidered', Minos I6, 52-66.

Fotou, V. 2004. 'Unpublished building remains from Evans's trial pits of $1900-02$ at Knossos', in Cadogan, G., Hatzaki, E. and Vasilakis, A. (eds), Knossos: Palace, City, State: Proceedings of the Conference in Herakleion organised by the British School at Athens and the 23rd Ephoreia of Prehistoric and Classical Antiquities of Herakleion, in November 2000, for the Centenary of Sir Arthur Evans's Excavations at Knossos (BSA Studies I2; London), 83-II9.

Fotou, V. and Evely, D. forthcoming. 'New light on palace phasing in the Throne Room area, Knossos' (unpublished poster presentation at I2th International Cretological Congress, 2I-25 September 2016; Herakleion).

Goodison, L. 200I. 'From tholos tomb to throne room: perceptions of the sun in Minoan ritual', in Laffineur, R. and Niemeier, W.-D. (eds), POTNIA: Deities and Religion in the Aegean Bronze Age (Aegaeum 22; Liège and Austin), 77-88.

Goodison, L. and Morris, C. I998. 'Beyond the "Great Mother": the sacred world of the Minoans', in Goodison, L. and Morris, C. (eds), Ancient Goddesses: The Myths and the Evidence (London), II3-32.

Gothein, M.L. and Wright, W.P. (eds) I928. A History of Garden Art (London and Toronto).

Günkel-Maschek, U. 20I2. 'Spirals, bulls, and sacred landscapes: the meaningful appearance of pictorial objects within their spatial and social contexts', in Panagiotopoulos, D. and Günkel-Maschek, U. (eds.), Minoan Realities: Approaches to Images, Architecture, and Society in the Aegean Bronze Age (Louvain-la-Neuve and Paris), II5-39.

Günkel-Maschek, U. 20I6. 'Establishing the Minoan "Enthroned Goddess" in the Neopalatial period: images, architecture, and elitist ambition', in Alram-Stern, E., Blakolmer, F., Deger-Jalkotzy, S., Laffineur, R. and Weilhartner, J. (eds), Metaphysis. Ritual, Myth and Symbolism in the Aegean Bronze Age (Aegaeum 39; Leuven and Liège), $255-62$.

Hägg, R. I986. 'Die göttliche Epiphanie im minoischen Ritual', $A M$ I0I, 4I-62.

Hägg, R. I988. 'The last ceremony in the throne room at Knossos', Opuscula Atheniensia I7, 99-106.

Hallager, E. I977. The Mycenaean Palace at Knossos. (Medelhavsmuseet, Memoir I; Stockholm).

Hallager, E. I978. 'The history of the palace at Knossos in the Late Minoan period', $S M E A$ I9, I7-33.

Harlan, D. 20II. 'The cult of the dead, fetishism, and the genesis of an idea: megalithic monuments and the tree and pillar cult of Arthur J. Evans', EFA I4, 210-30. 
Hatzaki, E. 2007. 'Final Palatial (LM II - LM IIIA2) and Postpalatial (LM IIIB - LM IIIC Early): the MUM south sector, long corridor cists, MUM pits (8, IO-II), Makritikhos "Kitchen", MUM north platform pits and SEX southern half groups', in Momigliano, N. (ed.), Knossos Pottery Handbook: Neolithic and Bronze Age (Minoan) (BSA Studies I4; London), I97-25I.

Hatzaki, E. 20I I. 'From LM IB Marine Style to LM II marine motifs. Stratigraphy, chronology and the social context of a ceramic transformation: a response to Maria Andreadaki-Vlazaki', in Brogan, T.M. and Hallager, E. (eds), LM IB Pottery: Relative Chronology and Regional Differences (Monographs of the Danish Institute at Athens II:I; Athens), 75-87.

Hiller, S. 1987. 'Die Mykener auf Kreta, ein Beitrag zum Knossos-Problem und zur Zeit nach 1400 v. Chr. auf Kreta', in Buchholz, H.-G. (ed.), Ägäische Bronzezeit. Wissenschaftliche Buchgesellschaft (Darmstadt), 388-406.

Hiller, S. I996a. 'Knossos and Pylos. A case of special relationship?', Cretan Studies 5, 73-83.

Hiller, S. 1996b. 'Zur Rezeption Ägyptischer Motive in der Minoischen Freskenkunst', Agypten und Levante $6,83-105$

Hiller, S. 2006. 'The throne room and great east hall. Questions of iconography', in Tampakaki, E. and

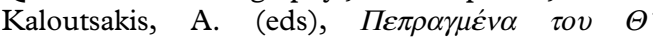

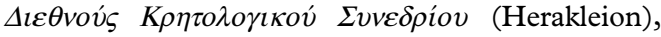
$245-58$.

Hiller, S. 2008. 'Ägyptische Entlehnungen im Griechischen. Zeugnis für bronzezeitlichen Ideentransfer', in Kyriatsoulis, A. (ed.), Austausch von Gütern, Ideen und Technologien in der Ägäis und im östlichen Mittelmeer. Von der prähistorischen bis zu der archaischen Zeit (Weilheim), I85-203.

Hiller, S. 20II. 'Palm and altar', in Gauss, W., Lindblom, M., Smith, R.A.K. and Wright, J.C. (eds), Our Cups Are Full: Pottery and Society in the Aegean Bronze Age. Papers Presented to Feremy B. Rutter on the Occasion of His 65th Birthday (Oxford), I04-I4.

Hitchcock, L.A. 20I0. 'The big nowhere: a master of animals in the throne room at Knossos?', in Counts, D.B. and Arnold, B. (eds.), The Master of Animals in Old World Iconography (Budapest), I07-I8.

Hood, M.S.F. 1978. The Arts in Prehistoric Greece (Harmondsworth)

Hood, M.S.F. I98I. The Bronze Age Palace at Knossos: Plan and Sections (BSA Supp. Vol. I3; London).

Hood, M.S.F. 2005. 'Dating the Knossos frescoes', in Morgan, L. (ed.), Aegean Wall Painting: A Tribute to Mark Cameron (British School at Athens Studies I3; London), 45-8I.

Hood, M.S.F., Fotou, V. and Evely, D. forthcoming. Knossos. The Area North and West of the Throne Room of the Palace (BSA Supp. Vol.; London).

Hopkins, C. I963. 'A review of the throne room at Cnossos', AfA 67, 416-ig.

Immerwahr, S.A. 1990. Aegean Painting in the Bronze Age (University Park, PA).

Karetsou, A. and Girella, L. 20I5. Kalochoraphitis. Two Chamber Tombs from the LM IIIA2-B Cemetery (Padova).

Karo, G. I930. Die Schachtgräber von Mykenai (Munich).
Kilian-Dirlmeier, I. I997. Das mittelbronzezeitliche Schachtgrab von Ägina (Kataloge vor- und frühgeschichtlicher Altertümer 27, Alt-Ägina 4.3; Mainz).

Klahr, L. 20II. 'Minoische Lustralbassins', Boreas 34, I-IOI.

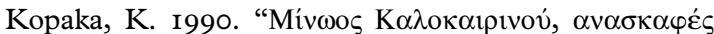

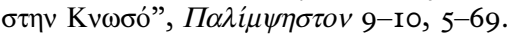

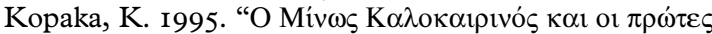

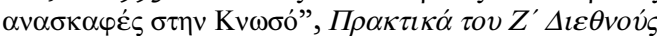

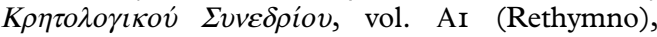
5OI-II.

Krzyszkowska, O.H. 1996. 'Furniture in the Aegean Bronze Age', in Herrmann, G. (ed.), The Furniture of Western Asia: Ancient and Traditional (Mainz), 85-103.

Lang, M.L. 1969. The Palace of Nestor, vol. 2: The Frescoes (Princeton).

Lebessi, A., Muhly, P. and Papasavvas, G. 2004. 'The Runner's Ring, a Minoan athlete's dedication at the Syme sanctuary, Crete', $A M$ i I9, I-3I.

Levi, D. I959. 'La villa rurale minoica di Gortina', $B d A$ 44, 237-64.

Long, C. 1974. The Ayia Triada Sarcophagus. A Study of Late Minoan and Mycenaean Funerary Practices and Beliefs (Gothenburg).

Macdonald, C.F. 2005. Knossos (London).

MacGillivray, J.A. 2009. 'Thera, Hatshepsut, and the Keftiu: crisis and response in Egypt and the Aegean in the mid-second millennium BC', in Heinemeier, J., Friedrich, W.L. and Warburton, D.A. (eds), Time's Up! Dating the Minoan Eruption of Santorini (Monographs of the Danish Institute at Athens Io; Athens), I54-70.

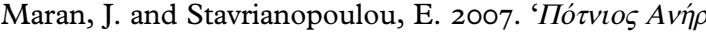
- Reflections on the Ideology of Mycenaean Kingship', in Alram-Stern, E. and Nightingale, G. (eds), Keimelion: Elitenbildung und Elitärer Konsum von der Mykenischen Palastzeit bis zur Homerischen Epoche (Vienna), 285-98.

Marinatos, N. I984a. 'The palm tree in Minoan iconography and religion', OpAth I5, I I5-22.

Marinatos, N. 1984b. Art and Religion in Thera. Reconstructing a Bronze Age Society (Athens).

Marinatos, N. 1987. 'Public festivals in the west courts of the palaces', in Hägg, R. and Marinatos, N. (eds.), The Function of the Minoan Palaces. Proceedings of the Fourth International Symposium at the Swedish Institute in Athens, IO-I6 Fune, I984 (Swedish Institute in Athens, Series in $4^{\circ}$, 35; Stockholm), I35-43.

Marinatos, N. I988. "The "African" of Thera reconsidered', OpAth I7, I37-4I.

Marinatos, N. I989a. 'The tree as a focus of ritual action in Minoan glyptic art', in Pini, I. (ed.), Fragen und Probleme der Bronzezeitlichen Ägäischen Glyptik (CMS Beiheft 3; Berlin), I27-44.

Marinatos, N. I989b. 'The Minoan harem. The role of eminent women and the Knossos frescoes', Dialogues d'histoire ancienne 15:2, 33-62.

Marinatos, N. 1993. Minoan Religion. Ritual, Image, and Symbol (Columbia, SC).

Marinatos, N. 2007. 'Rosette and palm on the bull frieze from Tell el-Dab'a and the Minoan solar goddess of Kingship,' in Bietak, M., Marinatos, N. and Palyvou, C. (eds), Taureador Scenes in Tell el-Dab'a (Avaris) and Knossos (Vienna), I45-50. 
Marinatos, N. 2009. 'The indebtedness of Minoan religion to Egyptian solar religion: was Sir Arthur Evans right?', fournal of Ancient Egyptian Interconnections $\mathrm{I}, \mathbf{2 2 - 8}$.

Marinatos, N. 2010. Minoan Kingship and the Solar Goddess: a Near Eastern Koine (Urbana).

Matz, F. 1958. Göttererscheinung und Kultbild im minoischen Kreta (Mainz).

Militello, P. I998. Haghia Triada I. Gli affreschi (Padua).

Mirié, S. I979. Das Thronraumareal des Palastes von Knossos: Versuch einer Neuinterpretation seiner Entstehung und seiner Funktion (Saarbruecker Beiträge zur Altertumskunde 26; Bonn).

Momigliano, N. I999. Duncan Mackenzie: a Cautious Canny Highlander and the Palace of Minos at Knossos (London).

Morgan, L. 1988. The Miniature Wall Paintings of Thera: A Study in Aegean Culture and Iconography (Cambridge).

Morgan, L. I995. 'Frontal face and the symbolism of death in Aegean glyptik', in Müller, W. (ed.), Sceaux Minoens et Mycéniens (CMS Beiheft 5; Berlin) $135-49$.

Morgan, L. 2010. 'An Aegean griffin in Egypt: the hunt frieze at Tell el-Dab'a', Ägypten und Levante 20, 303-23.

Murray, C. and Warren, P. 1976. 'Po-ni-ki-jo among the dye-plants of Minoan Crete', Kadmos I5:I, 40-60.

Niemeier, W.-D. I982. 'Mycenaean Knossos and the age of Linear B', SMEA 23, 219-88.

Niemeier, W.-D. 1985. Die Palaststilkeramik von Knossos: Stil, Chronologie und historischer Kontext (Berlin).

Niemeier, W.-D. I986. 'Zur Deutung des Thronraumes im Palast von Knossos', $A M$ IOI, 63-95.

Niemeier, W.-D. I987. 'On the function of the "throne room" in the palace at Knossos', in Hägg, R. and Marinatos, N. (eds), The Function of the Minoan Palaces (Stockholm), I63-8.

Nilsson, M.P. 1950. The Minoan-Mycenaean Religion and its Survival in Greek Religion, 2nd edn (Lund).

Palaima, T. 2006. 'Wanaks and related power terms in Mycenaean and later Greek', in Deger-Jalkotzy, S. and Lemos, I.S. (eds), Ancient Greece: From the Mycenaean Palaces to the Age of Homer (Edinburgh), 53-7I.

Palaima, T. 20I6. 'The ideology of the ruler in Mycenaean prehistory: twenty years after the missing ruler', in Koehl, R.B. (ed.), Studies in Aegean Art and Culture. A New York Aegean Bronze Age Colloquium in Memory of Ellen N. Davis (Philadelphia), I33-58.

Palmer, L.R. I969. The Penultimate Palace of Knossos (Rome).

Palmer, L.R. I983. 'Bull and palm tree in Aegean iconography', Nestor I0:9, I762-4.

Palyvou, C. 2005. Akrotiri Thera: An Architecture of Affluence 3,500 Years Old (INSTAP Prehistory Monographs I5; Philadelphia).

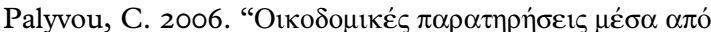

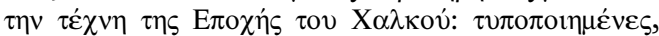

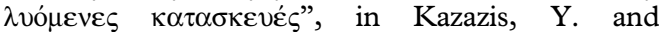

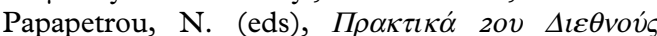

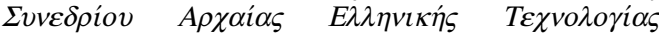
(Athens), 4I7-24.

Panagiotopoulos, D. 200I. 'Keftiu in context: Theban tomb-paintings as a historical source', $O f A$ 20:3, 263-83.
Panagiotopoulos, D. 20I2. 'Aegean imagery and the syntax of viewing', in Panagiotopoulos, D. and Günkel-Maschek, U. (eds), Minoan Realities. Approaches to Images, Architecture, and Society in the Aegean Bronze Age (Aegis 5; Louvain-la-Neuve), 63-82.

Papagiannopoulou, A. 2008. 'From pots to pictures: Middle Cycladic figurative art from Akrotiri, Thera', in Brodie, N., Doole, J., Gavalas, G. and

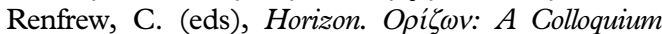
on the Prehistory of the Cyclades (Cambridge), 433-49.

Parkinson, R. 2008. The Painted Tomb-Chapel of Nebamun, Masterpieces of Ancient Egyptian Art in the British Museum (London).

Parrot, A. 1958. Mission archéologique de Mari II. Le palais, 2. Peintures murals (Paris).

Pelegatti, P. I96I-2. 'Osservazioni sui ceramisti del I palazzo di Festòs', CretChron I5-I6, 99-III.

Pendlebury, J.D. I939. The Archaeology of Crete (London).

Pernier, L. I935. Il palazzo minoico di Festòs, vol. I (Rome).

Pernier, L. and Banti, L. I95I. Il palazzo minoico di Festòs II. Il second palazzo (Rome).

Peters, M. 2008. 'Colour use and symbolism in Bronze Age Crete: exploring social and technological relationships', in Jackson, C.M. and Wager, E.C. (eds), Vitreous Materials in the Late Bronze Age Aegean (Sheffield Studies in Aegean Archaeology 9; Oxford), I87-208.

Platon, L. 2002. 'The political and cultural influence of the Zakros palace on nearby sites and in a wider context', in Driessen, J., Schoep, I. and Laffineur, R. (eds), Monuments of Minos. Rethinking the Minoan Palaces (Aegaeum 23; Liège and Austin), I $45-56$.

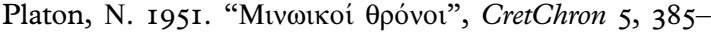
$4 \mathrm{I} 2$.

Platon, N. I97I. Zakros. The Discovery of a Lost Palace of Ancient Crete (New York).

Popham, M.R. I970. The Destruction of the Palace at Knossos. Pottery of the Late Minoan IIIA Period (SIMA I2; Gothenburg).

Popham, M.R. 1984. The Minoan Unexplored Mansion at Knossos (Oxford).

Preston, L. I999. 'Mortuary practices and the negotiation of social identities at LM II Knossos' $B S A$ 94, I3I-43.

Preston, L. 2004. 'A mortuary perspective on political changes in Late Minoan II-IIIB Crete', $A \mathcal{F A}$ I08:3, $32 \mathrm{I}-48$.

Puglisi, D. 20I2. 'Ritual performances in Minoan lustral basins. New observations on an old hypothesis', ASAtene 90, I99-2II.

Rehak, P. 1995. 'Enthroned figures in Aegean Art and the function of the Mycenaean Megaron', in Rehak, P. (ed.), The Role of the Ruler in the Prehistoric Aegean (Aegaeum II; Liège and Austin), 95-II8.

Rehak, P. I997. 'Aegean art before and after the LM IB Cretan destructions', in Laffineur, R. and Betancourt, P. (eds), TEXNH. Craftsmen, Craftswomen and Craftsmanship in the Aegean Bronze Age (Aegaeum I6; Liège and Austin), 5I-66.

Renfrew, C. 1998. 'Word of Minos: the Minoan contribution to Mycenaean Greek and the linguistic geography of the Bronze Age Aegean', CAf 8:2, 239-64. 
Renfrew, C. 2000. 'Locus iste: modes of representation and the vision of Thera', in Sherratt, S. (ed.), The Wall Paintings of Thera. Proceedings of the First International Symposium (Athens), I35-58.

Renfrew, C., Brodie, N., Morris, C. and Scarre, C. (eds) 2007. Excavations at Phylakopi in Melos 197477 (BSA Supp. Vol. 42; London).

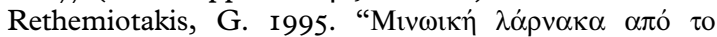

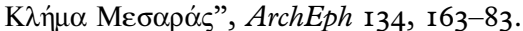

Reusch, H. I958. 'Zum Wandschmuck des Thronsaales in Knossos', in Grumach, E. (ed.), Minoica. Festschrift zum 8o. Geburtstag von fohannes Sundwall (Berlin), 334-56.

Reusch, H. I96I. 'Zum Problem des Thronraumes in Knossos', in Georgiev, V. and Irmscher, J. (eds), Minoica und Homer: Eine Aufsatzsammlung, (Berlin), 3I-9.

Reusch, H. I965. 'Zur Datierung des Thronraums von Knossos', Kadmos 3:2, I79-82.

Rüden, C. von. 20II. Die Wandmalereien aus Tall Mišrife/Qatna im Kontext überregionaler Kommunikation (Wiesbaden).

Rutkowski, B. I98I. Frügriechische Kultdarstellungen (Berlin).

Sarpaki, A. 2000. 'Plants chosen to be depicted on Theran wall paintings. Tentative interpretations', in Sherratt, S. (ed.), Proceedings of the First International Symposium 'The Wall Paintings of Thera', Petros M. Nomikos Conference Centre, Thera, Hellas, 30 August - 4 September 1997 (Athens), 65780.

Shank, E.B. 2003. 'The MuSIS 2007 system and its application to the throne room frescoes from Knossos' (unpublished $\mathrm{PhD}$ thesis, Temple University)

Shank, E.B. 2007. 'Throne room griffins from Pylos and Knossos', in Nelson, M., Williams, H., Betancourt, P. (eds), Krinoi kai Limenes: Studies in Honor of foseph and Maria Shaw (Philadelphia), I59-65.

Shank, E.B. forthcoming. 'The griffin motif - an evolutionary tale', in Vlachopoulos, A.G. (ed.), $X P \Omega \Sigma T H P E \Sigma$. Wall-painting and Vase-painting of the 2nd Millennium BC in Dialogue (Athens).

Shank, E.B. and Balas, C. 2003. 'The MuSIS 2007 and its application to the throne room fresco at Knossos', in Foster, K.P. and Laffineur, R. (eds), Metron: Measuring the Aegean Bronze Age (Aegaeum 24; Liège and Austin), I6I-5.

Shaw, M.C. 1986. 'The lion gate relief at Mycenae

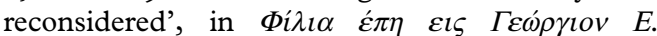

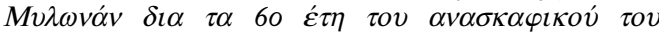
ह́ $\rho \gamma o v$ (Athens), I08-23.

Shaw, M.C. I993. 'The Aegean garden', $A \mathcal{F}$ 97:4, $66 \mathrm{I}-85$.

Shaw, M.C. 2005. 'The painted pavilion of the "Caravanserai" at Knossos', in Morgan, L. (ed.), Aegean Wall Painting: A Tribute to Mark Cameron (BSA Studies I3; London), 9I-III.

Shelmerdine, C.W. I999. 'Administration in the Mycenaean palaces: where's the chief?', in Galaty, M.L. and Parkinson, W.A. (eds), Rethinking Mycenaean Palaces: New Interpretations of an Old Idea (Los Angeles), I9-24.

Sherratt, E.S. and Galanakis, Y. forthcoming. 'Arthur Evans, Knossos and the world of archaeological replicas', in Simandiraki-Grimshaw, A. and Sattler, F. (eds), Replica Knowledge. Histories, Processes and Identities, 2-4 February 2017 (Berlin).
Smith, R.A.K. 20Io. Mochlos IIB: Period IV. The Mycenaean Settlement and Cemetery: The Pottery (INSTAP Prehistory Monographs 27; Philadelphia).

Soles, J. 20I6. 'Hero, goddess, priestess: new evidence for Minoan religion and social organisation', in Alram-Stern, E., Blakolmer, F., Deger-Jalkotzy, S., Laffineur, R. and Weilhartner, J. (eds), Metaphysis. Ritual, Myth and Symbolism in the Aegean Bronze Age (Aegaeum 39; Leuven and Liège), 247-53.

Szafrański, Z.E. 20I4. 'The exceptional creativity of Hatshepsut', in Galán, M., Bryan, B.M. and Dorman, P.F. (eds), Creativity and Innovation in the Reign of Hatshepsut (Studies in Ancient Oriental Civilization 69; Chicago), I25-37.

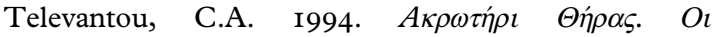

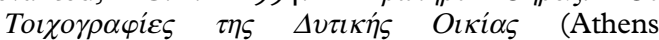
Archaeological Society Library I43; Athens).

Tsitsa, E. and Lakirdakidou, I. 2008. "IV.

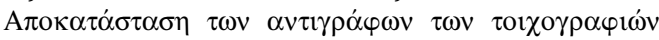

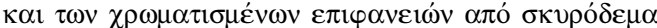

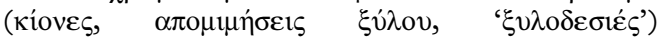
$\alpha v \alpha \sigma \tau \hat{\eta} \lambda \omega \sigma \eta \varsigma$ A. Evans", in Minos, N. (ed.),

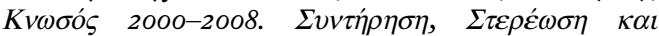

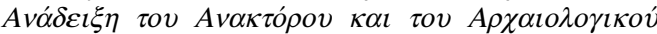
X⿳́㇒ov (Herakleion), I03-I6.

Tully, C.J. and Crooks, S. forthcoming. 'Enthroned upon mountains: iconography and the construction of power in the Aegean Bronze Age', in Naeh, L. and Brostowsky Gilboa, D. (eds), The Throne in Art and Archaeology: From the Dawn of the Ancient Near East until the Late Medieval Period (OREA; Vienna).

Vlachopoulos, A. 2000. 'The reed motif in the Thera wall paintings and its association with Aegean pictorial art', in Sherratt, S. (ed.), The Wall Paintings of Thera. Proceedings of the First International Symposium, Vol. II (Athens) 63I-56.

Vlachopoulos, A.G. 2007. 'Disiecta Membra. The wall paintings from the "Porter's Lodge" at Akrotiri, Thera', in Betancourt, P., Nelson, M. and Williams, H. (eds), Krinoi kai Limenes: Studies in Honor of foseph and Maria Shaw (Philadelphia), I3I-8.

Vlachopoulos, A.G. 2008. 'The wall paintings from the Xeste 3 building at Akrotiri: towards an interpretation of the iconographic programme', in Brodie, N., Doole, J., Gavalas, G. and Renfrew,

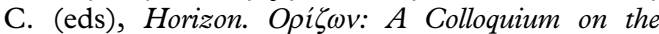
Prehistory of the Cyclades (McDonald Institute Monographs Cambridge; Cambridge), 45I-5.

Vlachopoulos, A.G. 20I5. 'Detecting 'Mycenaean' elements in the 'Minoan' wall paintings of a 'Cycladic' settlement: the wall paintings at Akrotiri, Thera within their iconographic koine', in Brecoulaki, H., Davis, J.L. and Stocker, S.R. (eds), Mycenaean Wall Painting in Context: New Discoveries, Old Finds Reconsidered (Institute of Historical Research, Section of Greek and Roman

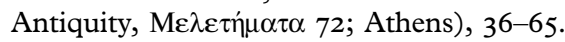

Vlachopoulos, A.G. 20I6. 'Images of physis or perceptions of metaphysis? Some thoughts on the iconography of the Xeste 3 building at Akrotiri, Thera', in Alram-Stern, E., Blakolmer, F., DegerJalkotzy, S., Laffineur, R. and Weilhartner, J. (eds), Metaphysis. Ritual, Myth and Symbolism in the Aegean Bronze Age (Aegaeum 39; Leuven and Liège), $375-85$. 
Walberg, G. 1976. Kamares. A Study of the Character of Palatial Middle Minoan Pottery (Boreas 8; Uppsala and Stockholm).

Warren, P.M. I969. Minoan Stone Vases (Cambridge).

Warren, P.M. I976. 'Did papyrus grow in the Aegean?', $A A A$ 9:I, 89-95.

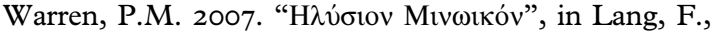
Reinholdt, C. and Weilhartner, J. (eds),

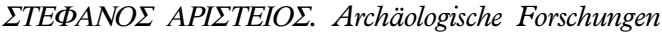
zwischen Nil und Istros, Festschrift für Stefan Hiller zum 65. Geburtstag (Vienna), 26I-70.

Waterhouse, H. I988. 'The flat alabastron and the last ritual in the Knossos throne room', $O F A$ 7:3, 36I-7.

Watrous, L.V. I99I. 'The origin and iconography of the Late Minoan painted larnax', Hesperia 60, 285-307.

Whittaker, H. 200I. 'Reflections on the socio-political function of Mycenaean religion', in Laffineur, $\mathrm{R}$. and Hägg, R. (eds) POTNIA. Deities and Religion in the Aegean Bronze Age (Aegaeum 22; Liège and Austin), 355-60.
Whittaker, H. 2015. 'The hidden ruler: art and politics in Minoan Crete', fournal of Ancient Egyptian Interconnections 7:3, 90-4.

Wiener, M.H. 20I5. 'The Mycenaean conquest of Minoan Crete', in Cadogan, G., Macdonald, C. F., Hatzaki, E. and Andreou, S. (eds), The Great Islands: Studies of Crete and Cyprus presented to Gerald Cadogan (Athens), I3I-42.

Winter, I.J. 2003. 'Ornament and the "rhetoric of abundance" in Assyria', ErIsr 27, 252-64.

Younger, J.G. I995. 'Bronze Age representations of Aegean bull-games, III', in Laffineur, R. and Niemeier, W.-D. (eds), POLITEIA: Society and State in the Aegean Bronze Age (Aegaeum I2; Liège and Austin), 507-45.

Zouzoula, E. 2007. 'The fantastic creatures of Bronze Age Crete', (unpublished $\mathrm{PhD}$ thesis, University of Nottingham).

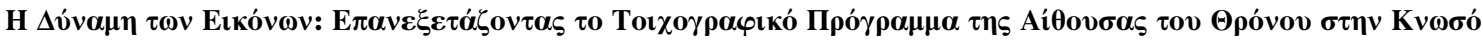

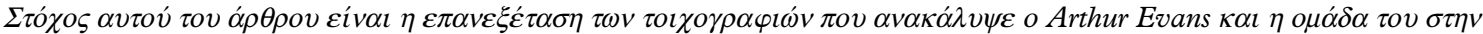

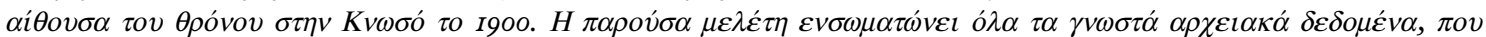

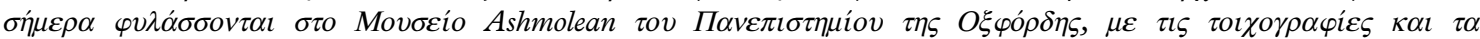

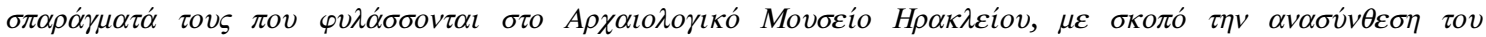

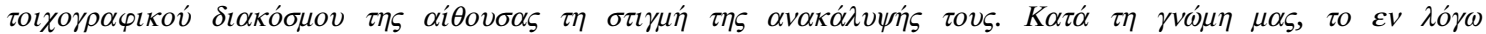

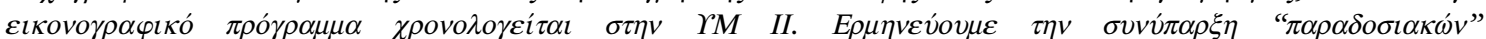

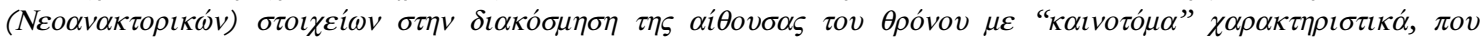

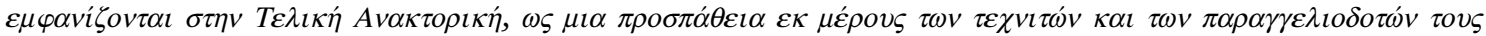

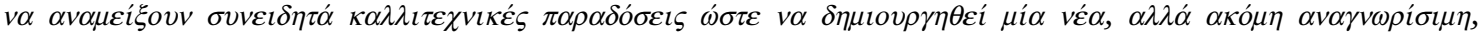

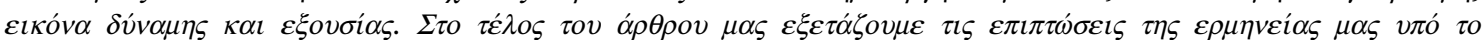

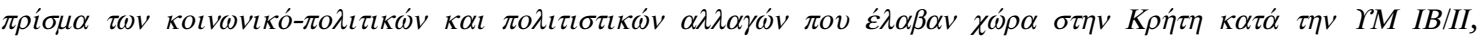

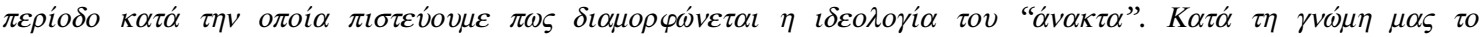

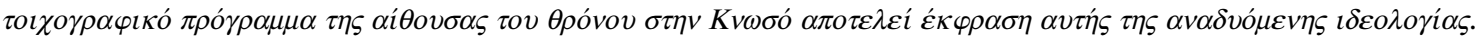

